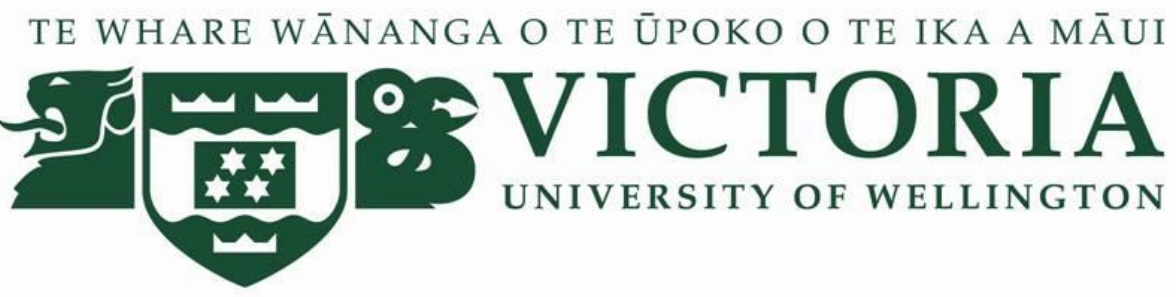

AUDITOR PROVIDED TAX SERVICES, INCOME SHIFTING, AND DEFAULT RISK

By

Arfian Erma Zudana

A thesis

submitted to the Victoria University of Wellington in fulfilment of the requirements for the degree of Doctor of Philosophy in Accounting

Victoria University of Wellington 
This page is intentionally left blank. 


\section{RESEARCH SUPERVISOR}

\section{Professor Tony van Zijl}

Professor of Accounting and Financial Management

Director, Centre of Accounting, Governance, and Taxation Research

Victoria Business School,

Victoria University of Wellington,

New Zealand

\section{Professor Balasingham Balachandran}

Professor of Corporate Finance

La Trobe Business School,

La Trobe University,

Australia 
This page is intentionally left blank. 


\section{ACKNOWLEDGEMENT}

I would like to extend my sincere thanks to my supervisors, Professor Tony van Zijl and Professor Balasingham Balachandran for their support and guidance.

I would also like to thank Lembaga Pengelola Dana Pendidikan, Indonesia, for the support for completing this thesis. I am grateful to Professor Bambang Sudibyo, Dr. Singgih Wijayana, and all staff at the Faculty of Economics and Business, Gadjah Mada University, Indonesia for their support.

The completion of this thesis would not have been possible without the support and assistance of so many people who could not all be recognised individually. In particular, to all the staff of the School of Accounting \& Commercial Law for their support and understanding during my study at Victoria University of Wellington. Also, a huge thanks to my research colleagues at the School of Accounting \& Commercial Law, especially those who started in year 2016, for sharing of knowledge and engaging in discussion.

I would also like to thank Dr. Scott D. Dyreng for help in understanding the income shifting model and Dr. Jonathan Brogaard, Dr. Ying Xia, and Dr. Huu Nhan Duong for help in understanding the distance-to-default measure.

Nobody has been more important in my Ph.D. journey than the members of my family. I would like to thank my mothers, Mas 'amah and Ida Djuraidah and fathers, Abu Zarowi and Tjejep Rustandi, my brothers, Zuhdy Mas Fury and Ahmad Zubaidi, and my sisters, Rahmah Dwi Noor Wita Imtikhanah and Nelfyeni, for your prayers, advice, and motivation. A very special thanks to my wife Anindita Rustandi and my son Abirajada Jembar Samudro for their endless support, sacrifice, and patience. For KH. Mustofa Bisri (Mbah Mus), Emha Ainun 
Nadjib (Mbah Nun), KH. Nawawi, Kiai Kanjeng, and all penggiat Maiyah, thank you for the spiritual support you have given to me. Thanks to my Chamber33 friends, Mas Yunus, and all of my close friends, thank you for all your jokes and entertaining support. Above all, to the Great Almighty Allah SWT for the wisdom He has bestowed upon me, the strength, and good health during my stay in this world. Alhamdulillahirobbil'alamin, La haula wala quwata illa billahil 'aliyil 'adim. 


\section{DECLARATION}

I hereby confirm that the work presented in this thesis is my own and original work that has been carried through the School of Accounting and Commercial Law, Victoria University of Wellington, during my candidature as a Ph.D. student. I declare that the material of this thesis has not been submitted either in whole or in part for the award of any other diploma at this or any other university. To the best of my knowledge and belief, it contains no material previously published or written by other person or institutions except where due reference has been made.

Arfian Erma Zudana

17 March 2020 
This page is intentionally left blank. 


\begin{abstract}
This study investigates two capital markets effects of auditor provided tax services (APTS), a particular form of auditor provided non-audit services (APNAS). Firstly, this study examines the influence of APTS on income shifting by United States of America (U.S.) multinational companies and, secondly, this study examines the impact of APTS on default risk of all U.S. companies.

There are two competing hypotheses on the impact of APNAS on the quality of the work of auditors and the empirical evidence is mixed. One strand of literature suggests that APNAS provide knowledge spillover effects and thus improve the quality of the work of the auditor. The other strand of literature suggests that APNAS impair the independence of the auditor and therefore lead to a decrease in the quality of the audit. APNAS may thus increase or decrease the value of audit as a governance mechanism. The U.S. Securities Exchange Commission (SEC) has banned several previously allowed APNAS such as bookkeeping, financial information systems design and implementation, appraisal and valuation, and internal audit. However, the SEC continues to permit auditors to provide tax services.

This study extends the literature on APNAS by examining the effect of APTS on income shifting by multinational companies and on default risk. Using a sample of 10,248 firm-year observations on U.S. multinationals over the period 2002 - 2015 and the income shifting measurement model developed by Dyreng and Markle (2016), this study finds that APTS reduce outbound income shifting, which is consistent with knowledge spillover rather than impairment of independence. The result holds after addressing potential endogeneity concern and
\end{abstract}


is robust to excluding observations from the financial crisis periods. Furthermore, the result holds after including firm-specific characteristics as influences on the income shifting parameters.

Using a sample of 21,364 firm-year observations on U.S. firms over the period 2003 - 2016, this study finds that APTS have a positive relationship with default risk, consistent with impaired independence of the auditor. The result holds after addressing potential endogeneity concern and is robust to excluding the global financial crisis period. The effects of APTS on income shifting and default risk are therefore opposite in direction. However, the positive relationship between APTS and default risk is weaker for firms with high institutional holdings and a strong information environment, indicating that stronger corporate governance mitigates the impact of APTS on default risk. Furthermore, this study finds that the channel for the effect of APTS on default risk appears to be earnings quality. That is, APTS lower audit quality, thereby lowering earnings quality and increasing default risk. Given the cost of default, this is an important finding.

Thus, taking the results on income shifting and default risk in combination, the question of the SEC continuing to permit auditors to provide tax services is left open to question. 
TABLE OF CONTENTS

RESEARCH SUPERVISOR ...................................................................ii

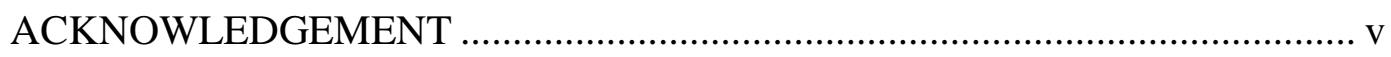

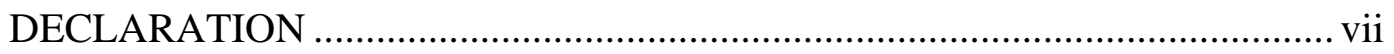

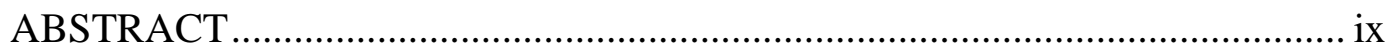

TABLE OF CONTENTS ............................................................................

LIST OF ABBREVIATIONS ....................................................................... $\mathrm{xV}$

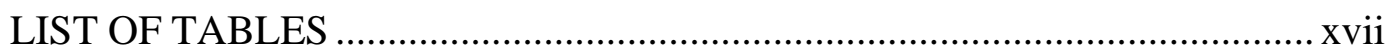

LIST OF APPENDICES ……………………..............................................

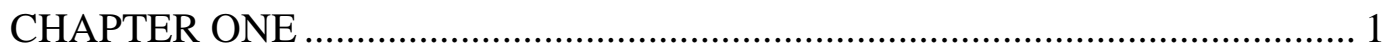

INTRODUCTION …………………………………………………….... 1

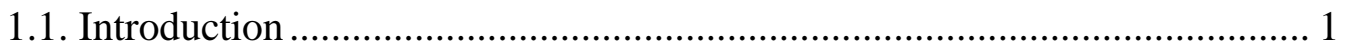

1.2. Motivation and Research Questions ……………………......................... 2

1.3. Summary of Findings ........................................................................... 4

1.4. The Remaining Chapters of the Thesis ...................................................... 5

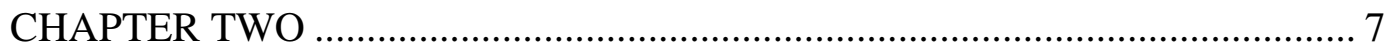

AUDITOR PROVIDED TAX SERVICES AND INCOME SHIFTING ................ 7

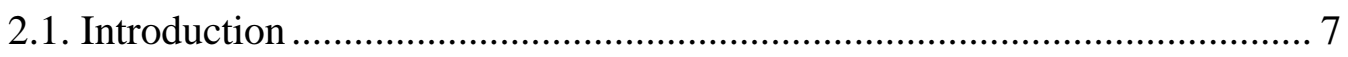

2.2. Background, Literature Review, and Hypotheses Development ............... 10

2.2.1. Study Background ....................................................................... 10 
2.3.2. Sample

2.4. Empirical Results: Auditor Provided Tax Services and Income Shifting.. 34

2.4.1. Descriptive Statistics

2.4.2. Baseline Result

2.4.3. Endogeneity Test

2.4.4. Additional Tests

2.5. Conclusion

3.1. Introduction

3.2. Literature Review and Hypotheses Development.

3.2.1. Default Risk

3.2.2. The determinants of default risk 52

3.2.3. Hypotheses Development .55

3.3. Measures of the key variables, Research Design, and Sample 56

3.3.1. Measure of Default Risk 56 
3.4.5. Robustness Checks: Alternative Measures of Default Risk.

3.5. Institutional Ownership, Auditor Provided Tax Services, and Default Risk

3.6. Information Environment, Auditor Provided Tax Services, and Default Risk

3.6.2. Liquidity.

3.8. Conclusion 
4.3 Limitations 92

4.3.1. Limitations: APTS and Income Shifting..... 93

4.3.2. Limitations: APTS and Default Risk 94

4.4. Future Research 94

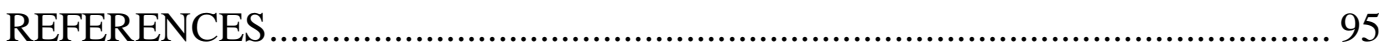

APPENDIX 1 - DEFINITION OF VARIABLES ........................................... 105

APPENDIX 2 - APTS AND INCOME SHIFTING - PEARSON

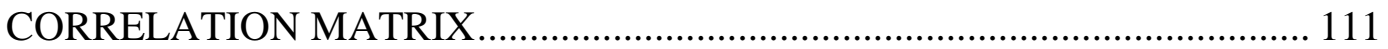
APPENDIX 3 - APTS AND DEFAULT RISK - PEARSON CORRELATION MATRIX 113

APPENDIX 4 - SUMMARY OF KEY EMPIRICAL STUDIES CITED 115 
LIST OF ABBREVIATIONS

\begin{tabular}{ll}
\hline ACRONYM & MEANING \\
\hline APNAS & Auditor Provided Non-audit Services \\
CEO & Auditor Provided Tax Services \\
EDF & Chief Executive Officer \\
FASB & Expected Default Frequency \\
IRS & Financial Accounting Standards Board \\
PIN & Internal Revenue Service \\
PSM & Probability of Insider Trading \\
R\&D & Propensity Score Matching \\
SEC & Research and Development \\
SUR & Securities and Exchange Commission \\
U.K. & Seemingly Unrelated Regression \\
U.S. & United Kingdom \\
\hline
\end{tabular}


This page is intentionally left blank. 


\section{LIST OF TABLES}

Table 2. 1. Sample Selection - APTS and Income Shifting .......................... 32

Table 2. 2. Descriptive Statistics - APTS and Income Shifting .................... 35

Table 2. 3. Baseline Result - APTS and Income Shifting ….......................... 36

Table 2. 4. First-Stage Model - APTS and Income Shifting ......................... 40

Table 2. 5. Endogeneity - APTS and Income Shifting …........................... 41

Table 2. 6. Crisis Periods - APTS and Income Shifting .............................. 42

Table 2. 7. Firm Characteristics - APTS and Income Shifting ..................... 44

Table 3. 1. Sample Selection - APTS and Default Risk ............................... 59

Table 3. 2. Descriptive Statistics - APTS and Default Risk .......................... 61

Table 3. 3. Baseline Result - APTS and Default Risk.................................... 64

Table 3. 4. First-Stage Model - APTS and Default Risk .............................. 67

Table 3. 5. Endogeneity - APTS and Default Risk …....................................6 68

Table 3. 6. Global Financial Crisis - APTS and Default Risk ...................... 70

Table 3. 7. Alternative Measures of Default Risk - APTS and Default Risk 73

Table 3. 8. Institutional Ownership - APTS and Default Risk ..................... 75

Table 3. 9. Analyst Following and PIN - APTS and Default Risk ................ 80

Table 3. 10. Liquidity - APTS and Default Risk ......................................... 82

Table 3. 11. Earnings Quality Channel - APTS and Default Risk................. 85

Table 3. 12. Earnings Quality Channel - APTS and Default Risk -

Confirmatory Tests 86

Table 3. 13. Earnings Quality Channel - APTS and Default Risk - Additional Test 
This page is intentionally left blank. 


\section{LIST OF APPENDICES}

APPENDIX 1 - DEFINITION OF VARIABLES............................ 105

APPENDIX 2 - APTS AND INCOME SHIFTING - CORRELATION

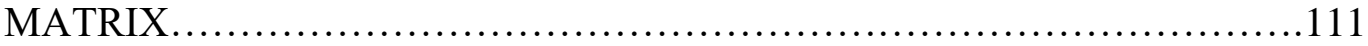

APPENDIX 3 - APTS AND DEFAULT RISK - CORRELATION

MATRIX.

113

APPENDIX 4 - SUMMARY OF KEY EMPIRICAL STUDIES

CITED. 
This page is intentionally left blank. 


\section{CHAPTER ONE}

\section{INTRODUCTION}

\subsection{Introduction}

The United States of America (U.S.) Securities Exchange Commission (SEC) has in the past engaged in extensive deliberation on the possibility that auditor provided non-audit services (APNAS) might impair the independence of the auditor. As a result, the SEC banned several previously allowed APNAS such as bookkeeping, financial information systems design and implementation, appraisal and valuation, and internal audit. However, the SEC continues to permit auditors to provide tax services (APTS), a particular form of APNAS. This study investigates two capital market effects of APTS, neither of which has been addressed in the literature. Firstly, this study examines the influence of APTS on income shifting by U.S. multinational companies and, secondly, this study examines the impact of APTS on default risk of U.S. companies.

There are two competing hypotheses on the impact of APNAS on the quality of the work of auditors and the empirical evidence is mixed. APNAS may provide knowledge spillover effects and thus improve the quality of the audit. Alternatively, APNAS may impair the independence of the auditor and therefore lead to a decrease in the quality of the audit. APNAS may thus increase or decrease the value of audit as a governance mechanism.

This study finds that APTS have a downward impact on outward income shifting, consistent with APTS generating knowledge spillover effects. However, this study also finds that APTS are associated with increased default risk, 
consistent with impaired independence of the auditor. The findings on the impacts of APTS on income shifting and default risk are therefore opposite in direction.

The rest of this chapter is organized as follows: Section 1.2 presents the motivation and research questions for the thesis. Section 1.3 provides the summary of findings. Section 1.4 presents an overview of the remaining chapters of this thesis.

\subsection{Motivation and Research Questions}

Both income shifting and default risk are important economic issues. For example, the OECD (OECD, 2015) estimates that tax avoidance activities reduce global tax revenue by $4 \%$ to $10 \%$, and income shifting is likely to be a leading factor for this result; Davydenko, Strebulaev, and Zhao (2012) estimate that for U.S. firms the mean (median) cost of default is $21.7 \%(22.1 \%)$ of the market value of assets. Improved understanding of the factors influencing income shifting and default risk is therefore a worthwhile target for research.

Both income shifting and default risk have been the subject of a number of studies. Similarly, the impact of APTS has been studied in relation to a number of capital market effects. However, to date, the possible impact of APTS on income shifting or on default risk has not been addressed in the empirical literature. This study addresses this gap.

The empirical evidence on the impact of APNAS on the quality of audit is mixed. Some studies have found a positive outcome from the joint provision of audit and non-audit services by auditors. Specifically for APTS, Kinney, Palmrose, and Scholz (2004) find a negative association between APTS and restatement of financial statements. Robinson (2008) finds that APTS are 
positively related to issue of a correct going-concern opinion prior to the filing for bankruptcy. On the other hand, other studies find that, in general, APNAS impair auditor independence. Frankel, Johnson, Nelson, Kinney, and Libby (2002) find that the level of non-audit fees is related to the likelihood of reporting a small earnings surprise, the size of absolute discretionary accruals, and the magnitude of income increasing and income decreasing discretionary accruals. In a similar vein, Ferguson, Seow, and Young (2004) find evidence that the economic bonding resulting from non-audit services induces auditors to be more lenient on earnings management activities.

The research questions are therefore as follows:

1. Are APTS associated with income shifting by multinational companies?

2. Are APTS associated with default risk?

To address the first research question, this study uses the income shifting model developed by Dyreng and Markle (2016) for analysis of the effect of financial constraints on shifting of domestic and foreign pre-tax earnings. This study applies this model to test, instead, for the impact of APTS on income shifting.

To test the second research question, this study regresses company fees for APTS on a measure of default risk. The primary measure of default risk used is the modified Altman Z-Score (Altman, 1983) but in robustness tests this study also uses two alternative measures, the original Altman Z-Score (Altman, 1968) and the expected default frequency (EDF) developed by Bharath and Shumway (2008). 


\subsection{Summary of Findings}

This study finds that the impacts of APTS on income shifting and default risk are opposite in direction. Using a sample of 10,248 firm-year observations on U.S. multinational companies over the period 2002 - 2015, this study finds that APTS lower income shifting, consistent with knowledge spillover effects. The result holds under tests for impact of firm characteristics and the influence of crisis periods.

To test for the impact of APTS on default risk, this study uses a sample of 21,364 firm-year observations on U.S. firms over the period 2003 - 2016, and this study finds that APTS increase default risk, consistent with impairment of independence. This result is robust to test for the impact of the global financial crisis period and the use of alternative measures of default risk. This study also finds that the positive relationship is stronger with lower institutional holdings. This suggests that stronger corporate governance may mitigate the impact of APTS on default risk. This study also finds that the impact of APTS on default risk is stronger with a higher degree of information asymmetry. Finally, I find evidence that earnings quality may be the channel for the influence of APTS on default risk. That is, APTS lower audit quality, thereby lowering earnings quality and increasing default risk. Given the cost of default, this is an important finding.

The examination of the impact of APTS on the two capital markets phenomena indicates that the effects are opposite in direction. One obvious possible reason for the finding of opposite effects is simply that income shifting relates to just a segment of all U.S. firms whereas default risk applies for all U.S. firms. It is not unusual to find in empirical research that a particular effect is 
different across different populations of firms or across different time periods. It may be that the difference results from differing degrees of importance for audit as a governance mechanism. In the case of income shifting the auditor is probably the only external party with a detailed knowledge of income shifting arrangements and therefore plays a key role in managing the risks associated with entering into such arrangements. Furthermore because of the larger size of multinationals, the auditor may provide a higher level of quality in audit services. For default risk, a number of non-audit governance mechanisms may mitigate the impact of APTS as indicated by the tests on institutional holdings and the information environment.

However, taking the results on income shifting and default risk in combination, the question of the SEC continuing to permit auditors to provide tax services is obviously left open to question.

\subsection{The Remaining Chapters of the Thesis}

Chapter Two presents a review of the literature on APTS and income shifting, develops the hypotheses, and reports the results. Similarly, Chapter Three reviews the empirical literature on default risk, develops the hypotheses on the impact of APTS on default risk, and reports the results. Chapter Four provides the conclusions for the thesis, notes the contributions made, and discusses the limitations of the study. Finally, the chapter provides suggestions for future research. 
This page is intentionally left blank. 


\section{CHAPTER TWO}

\section{AUDITOR PROVIDED TAX SERVICES AND INCOME SHIFTING}

This chapter provides empirical evidence on the impact of APTS on income shifting behaviour of U.S. multinational companies. This chapter begins with an introduction in Section 2.1. Section 2.2 presents a review of the empirical literature on APTS and on income shifting, discussion on the institutional setting, and development of the hypotheses. Section 2.3 provides an explanation of the income shifting model used to test the hypotheses and the sample selection process. Section 2.4 starts with the descriptive statistics of the sample and is followed by the baseline regression results, test for endogeneity, and additional robustness tests. Finally, Section 2.5 concludes the chapter.

\subsection{Introduction}

This chapter investigates the relationship between APTS and income shifting by U.S. multinational companies. Klassen, Lisowsky, and Mescall (2016) find that more than $80 \%$ of companies hire their auditor as their tax advisor. In the empirical capital market literature, APTS and income shifting are generally considered separately (see, for example studies on APTS, Kinney et al. (2004), Robinson (2008), Fortin and Pittman (2008), Krishnan and Visvanathan (2011), Gleason and Mills (2011), Paterson and Valencia (2011), and Gleason, Mills, and Nessa (2018)); for example studies on income shifting, see Collins, Kemsley, and Lang (1998), Rego (2003), Klassen and Laplante (2012a), Klassen and Laplante (2012b), Dharmapala and Riedel (2013), and Dyreng and Markle (2016)). In contrast, this study examines APTS and income shifting simultaneously and thus addresses a significant gap in the literature. 
Before the recent amendments to the tax rules, U.S. multinationals were taxed on their worldwide income. However, they were not liable for the U.S. tax on income generated in other countries until it was repatriated to the U.S. For their repatriated and U.S. income, these multinationals faced a high tax rate compared to the rate applied in other countries. This regime, therefore, created an incentive for U.S. multinationals to leave their foreign generated income abroad and to shift their U.S. generated income to low rate foreign jurisdictions. The higher the amount of income shifted by the multinationals, the lower their effective tax rate would be as the higher would be the proportion of income taxed at relatively lower rates. However, this income shifting behaviour could be costly and carry risks such as litigation risk and reputation risk. Furthermore, risky financial arrangements might result from the process of smoothing and concealing this behaviour.

A number of studies indicate that APTS bring positive effects (see, for example, Kinney et al. (2004), Robinson (2008), Gleason and Mills (2011), Paterson and Valencia (2011), Krishnan and Visvanathan (2011), Seetharaman, Sun, and Wang (2011), Lisic (2014), and De Simone, Ege, and Stomberg (2015)). Kinney et al. (2004) find that APTS are negatively related to the restatement of Form 10-K or Form 10-Q. Robinson (2008) finds that APTS induce the issuance of a correct going-concern opinion prior to a bankruptcy filing. Thus, appointment of the auditors as a tax consultant might not impair their independence, on the contrary, APTS could lead auditors to gain a better understanding of their clients operations and therefore a higher probability that auditors would limit managers' opportunistic behaviour such as income shifting activities. 
On the other hand, some studies find that APNAS, in general, may impair auditor independence. For example, Frankel et al. (2002) find that the level of non-audit fees is related to the likelihood of reporting a small earnings surprise, the magnitude of absolute discretionary accruals, and the magnitude of income increasing and income-decreasing discretionary accruals. In a similar vein, using three alternative measures of earnings management and APNAS, Ferguson et al. (2004) find that APNAS are related to earnings management. Specifically for APTS, Maydew and Shackelford (2007) argue that APTS may lower the likelihood of audit partners challenging clients' tax work as it has been prepared by their tax colleagues in the same audit firm. Thus, an auditor with lower independence might accommodate the willingness of managers of U.S. multinationals to shift their income to and from foreign jurisdictions irrespective of the associated risks.

Using a sample of 10,248 firm-year observations on U.S. multinationals over the period 2002 - 2015, this study finds that APTS are related to lower income shifting activities which provides supporting evidence for knowledge spillover effects rather than impairment of independence. This result is robust to tests for the impact of financial crisis periods and the influence of firm characteristics.

Studies on APTS include the effect of APTS on (i) earnings quality (Krishnan and Visvanathan, 2011) and (Lisic, 2014), (ii) value relevance (Krishnan, Visvanathan, and $\mathrm{Yu}, 2013$ ), (iii) corporate debt pricing (Fortin and Pittman, 2008), and (iv) tax avoidance (Cook, Huston, and Omer, 2008) and (McGuire, Omer, and Wang, 2012). Previous studies on income shifting by 
multinationals have considered such drivers as dominance of foreign operations (Rego, 2003), mitigation of earnings shocks (Dharmapala and Riedel, 2013), and financial constraints (Dyreng and Markle, 2016), Thus, while previous studies have considered APTS and income shifting separately none have considered the possibility of a link between these phenomena. This study addresses this gap and therefore has the potential to provide evidence on the SEC's policy of continuing to allow auditors to provide tax services.

\subsection{Background, Literature Review, and Hypotheses Development}

Section 2.2.1 discusses the institutional background of the study. Section 2.2.2 presents the literature review on APTS, and Section 2.2.3 the literature review on income shifting. Next, Section 2.2.4 provides the hypotheses development for this study.

\subsubsection{Study Background}

Global tax avoidance has reached a critical level. A 2015 OECD report, (OECD, 2015), estimates that avoidance activities reduce global tax revenue by between $4 \%-10 \%$. It is believed that aggressive income shifting strategies by multinationals is one of the leading factors. However, it is a more severe problem for countries that have a relatively high corporate tax rate and tax system that incentivizes income shifting activities. Several countries, such as the U.S., have both of those characteristics.

For the year ended 2016, U.S. firms faced a federal corporate tax rate in the range of $15-35 \%$. The applicable level in the range increases with increasing income in which the rate for the highest income bracket is $35 \%$. In addition, U.S. 
firms face income tax at the state level. This rate varies across the states. 1 According to 2016 OECD data, the combined federal and state U.S. corporate tax rate, on average, is $38.92 \%$ which is one of the highest tax rates in the world.2 This creates incentives for U.S. multinationals to hide their income in foreign jurisdictions by income shifting scheme.

Aside from the tax rate issue, U.S. multinational companies are also incentivized to shift income by the U.S. worldwide tax system. Before the recent amendments to the tax rules, U.S. firms were taxed on the sum of their domestic and foreign incomes. However, they were not liable for the U.S. tax on income generated in foreign countries until it was repatriated to the U.S. For example, a U.S. multinational operating in Ireland, was liable for tax on income generated in Ireland at the rate of $12.5 \%$ but the balance of $26.5 \%$ for U.S. tax was not payable until the income was repatriated to the U.S. This tax deferral advantage would be increased by the use of tax havens. Continuing the example, although the income is generated in Ireland, the multinational might have entered into arrangements to effectively shift the income to a tax haven country where an even lower (or zero) rate of tax is imposed. Furthermore, it might be possible for the multinational to shift some of its income generated in the U.S. to Ireland or tax haven countries by transfer pricing or other schemes and thus augment the deferral advantage.

Those factors have provided incentives for U.S. multinationals to shift their income to foreign jurisdictions. Clausing (2009) estimates that $\$ 87$ billion was

1 According to KPMG data, income taxes at local state government level range from $0-12 \%$. (see https://home.kpmg.com/xx/en/home/services/tax/tax-tools-and-resources/tax-ratesonline/corporate-tax-rates-table.html)

2 The OECD statutory income tax rate data can be found here: https://stats.oecd.org/Index.aspx?DataSetCode=CTS_CIT 
shifted out of the U.S. in the year 2002. More recent studies find that U.S. multinationals have become more aggressive income shifters. For example, Klassen and Laplante (2012a) find that, on average, there is an additional \$26 million of shifted income per year during 2005-2009 relative to 1998-2002 for each company. They find that, in aggregate, companies with a low average foreign tax rate shifted $\$ 10$ billion per year more out of the U.S. during 20052009 than during 1998-2002. Furthermore, specific to target locations, Dyreng and Markle (2016) find that during the 1998 - 2011 period, U.S. multinationals with tax haven operations shifted \$26 million per year more than the multinationals not using tax havens.

\subsubsection{Literature Review on Auditor Provided Tax Services}

In 2003, in order to strengthen auditor independence, the SEC banned several, previously allowed, APNAS such as bookkeeping, financial information systems design and implementation, appraisal or valuation, actuarial, internal audit, management or human resource services, broker or dealer services, and legal and expert services unrelated to the audit. However, the SEC has continued to permit auditors to provide tax services to their audit clients.

There are two streams of research related on the effect of APTS. On the one hand, there are studies that have provided evidence in support of regulators continuing to allow auditors to serve as tax consultants for their audit clients. On the other hand, other studies conclude that APTS impair independence. The former group of studies support the view that APTS lead to knowledge spillovers and do not impair auditor independence. Simunic (1984) examines the decision of firms to purchase management advisory services and audit services when their 
production functions are interrelated and investigates the existence and pricing effect of knowledge spillovers. Using data on 263 U.S. companies during 1976 1977, the author finds that firms that purchase management advisory services have higher audit fees compared to firms that do not purchase those services. Simunic (1984) concludes that the observed fee increase is an indication of a beneficial knowledge spillover effect between the services.

Antle, Gordon, Narayanamoorthy, and Zhou (2006) investigate the relationship between audit fees, non-audit fees, and abnormal accruals in a simultaneous equations system. Using 2,294 firm-year observations on U.K. firms during 1994 - 2000, the authors find knowledge spillovers effect from auditing to non-audit services and from non-audit services to auditing. Furthermore, the authors find a negative relationship between non-audit fees and abnormal accruals. They argue that it indicates the productive effects of providing non-audit services.

Kinney et al. (2004) examine the relationship between APNAS and the restatement of financial statements using 617 restating/non-restating pairs of U.S. companies during the period 1995 - 2000. The authors do not find a statistically significant relationship between restatement and financial information system design and implementation fees or internal audit services fees. Further, the authors do find a significant positive relationship between unspecified APNAS and restatements. In contrast, they find a significant negative relationship between tax services fees and restatements. The authors argue that the results are indicative of benefits resulting from APTS. 
Robinson (2008) investigates the relationship between APTS and auditor independence as reflected in the issue of correct going-concern opinions. To test the issue, the author uses data on 209 U.S. bankrupt firms over the period 2001 2004. The author does not find a significant relationship between either audit or non-audit fees to the probability of issuing a going-concern opinion. However, after dividing the non-audit fees into tax and non-tax fees, the author finds a positive relationship between tax fees and the issuance of a correct going-concern opinion prior to a bankruptcy filing.

Fortin and Pittman (2008) investigate the value of APTS in respect of bondholders. Using 694 public debt issues in the U.S. over the period 2001 2005 , they find a lower yield spreads for firms that pay proportionately larger tax fees to their auditor. Furthermore, they find that the negative relationship between APTS and yield spread is more pronounced when they isolate issues made by firms with greater information asymmetry. Specifically, they find that the negative relationship is stronger for shorter maturity bonds and financial firms.

Gleason and Mills (2011) investigate the association between APTS and the ability of firms to estimate their tax reserve in the face of an Internal Revenue Service (IRS) investigation. They argue that the provision of tax services by auditors may impair audit quality by lowering auditor independence. On the other hand, APTS may lead to improvement of audit quality, thereby better financial reporting. Using 497 firm-year observations on U.S. firms during the $2000-2002$ period, the authors find that firms that purchase APTS are better able to estimate the tax contingency and thus have a lower tax reserve. The results are consistent with a knowledge spillover effect. 
Paterson and Valencia (2011) investigate the relationship between APNAS and auditor independence and distinguish between recurring and non-recurring APNAS. Using data on 7,042 U.S. firms during the period 2003 - 2006, the authors find that recurring APTS are negatively related to restatements. However, they find that non-recurring APTS are positively related to restatements and thus conclude that the evidence in earlier studies indicating knowledge spillover rather than impairment of independence must have been dominated by recurring assignments.

Krishnan and Visvanathan (2011) examine whether APTS prevent earnings management and whether tax avoidance is related to APTS. Using 1,750 unique U.S. companies during the period 2000 - 2007, they find a negative relationship between APTS and earnings management as measured by loss avoidance. They also find that in the pre-SOX period, APTS are positively related to earnings management, while in the post-SOX period, APTS are negatively related to earnings management. Further, they do not find any evidence of APTS influencing tax avoidance.

Seetharaman et al. (2011) examine the association between APTS and taxrelated financial statement restatements in the post-SOX period. Using 2,116 U.S. restatement companies and 150 tax-related restatements companies, the authors find a significant negative relationship between APTS and tax-related financial restatements but they do not find a significant relationship between APTS and general financial restatements.

Lisic (2014) examines the influence of audit committee effectiveness on the relationship between APTS and earnings management through the tax expense 
account. Using data on 799 S\&P companies at the end of 2003, Lisic (2014) finds that APTS is negatively (positively) related to earnings management through tax expense for firms with audit committee effectiveness above (below) the median in the sample.

Krishnan et al. (2013) investigate the influence of APTS on investors' valuation. Using 27,919 firm-year observations on U.S. firms over 2000 - 2008 period, the authors find a positive relationship between the ratio of tax fees to total fees and the value-relevance of earnings. Moreover, they find a lower valuerelevance of earnings in the year when firms switch from auditor to other providers of tax services.

De Simone et al. (2015) examine the relationship between APTS and firms' internal control quality. They argue that purchase of APTS facilitates earlier assessment by the audit firm of the internal control environment relating to material transactions. Consequently, companies are better placed to mitigate internal control deficiencies and early prevent material weaknesses. Using data on 5,830 U.S. companies over the 2004 - 2012 period, they find a negative relationship between APTS and disclosure of material weaknesses and point to impact on internal control quality as a mechanism through which APTS improve overall financial reporting quality.

Gleason et al. (2018) investigate the adequacy and accuracy of tax reserves in term of Financial Accounting Standards Board (FASB) Interpretation No.48 and the influence of APTS on tax reserves. Using 2,798 firm-year observations on U.S. firms over the period 2003 - 2014, they find that both prior- and post- FIN 48, firms are adequately reserved for IRS tax assessments and settlements. They 
find that the overall adequacy or accuracy of reserves pre- and post-FIN 48 are not statistically different. Related to the impact of APTS, they find that, overall, firms with low APTS are under-reserved for IRS assessments, while firms with high ATPS are over-reserved prior to FIN 48. However, post-FIN 48, there is no difference between the adequacy of tax reserves for firms with a high or low level of APTS. Thus FIN 48 improves the availability of information to the extent of eliminating any significance for the knowledge spillover effect of APTS.

In contrast to the studies summarised above, a number of studies show that APNAS impair auditor independence. Frankel et al. (2002) examine whether the provision of APNAS is related to earnings management. They also examine the market reactions related to the disclosure of auditor fees. Using proxy statements filed by 3,074 U.S. firms during February - June 2001, the authors find a positive relationship between APNAS and the likelihood of reporting a small earnings surprise, the magnitude of absolute discretionary accruals, and the magnitude of income-increasing and income-decreasing discretionary accruals. However, they do not find a significant relationship between APNAS and small earnings surprise for larger firms. Overall, they conclude that the results provide evidence that firms purchasing APNAS engage in a greater degree of earnings management. Further, they find a significant negative relationship between abnormal returns and the disclosure of higher than expected non-audit fees. However, that relationship does not hold when longer event windows are used to measure abnormal returns.

Ferguson et al. (2004) extend previous research by investigating the relationship between the joint provision of audit and APNAS and earnings management using data on 610 United Kingdom (U.K.) firms over the period 
1996 - 1998. In general, they find that earnings management is positively related to APNAS. The authors find that the association between APNAS and restatements depends on whether the restatements are related to earnings or the balance sheet. Specifically, they find robust evidence that APNAS are positively related to earnings-related restatements, for all three measures of total non-audit services used in the study. However, they find a positive relationship between non-audit services and balance sheet related restatements for only one of the three measures, namely log of non-audit fees.

Abbott, Parker, Peters, and Raghunandan (2003) using proxy statements filed by 538 U.S. firms during February - June 2001, examine the association between audit committee characteristics and APNAS. They find that firms with audit committees that consist of all independent directors and meet at least four times during the year have a lower ratio of non-audit fees to audit fees.

Krishnan, Sami, and Zhang (2005) examine the relationship between APNAS and earnings response coefficient for the first, second, and third quarters following the release of proxies containing fee disclosures. Using proxy statements filed by 2,816 U.S. firms during 2001, they find a negative relationship between the ratio of non-audit fees to total fees and the earnings response coefficient. They also find a negative relationship between the amount of nonaudit fees and the earnings response coefficient. Those relationships exist in the first, second, and third quarters.

Francis and $\mathrm{Ke}$ (2006) investigate the effect of mandated fees disclosure on the market perceptions of auditor independence and earnings quality. To test the issue, they use data on 3,133 U.S. firms during the period of 1999 - 2002. They 
argue that if fee disclosure contains new information for investors and if they believe that APNAS may impair auditor independence, then investors will value the earnings of firms with higher non-audit fees lower than firms with lower nonaudit fees. They find that in the period of the fees disclosure, investors do not discount the earnings of firms that subsequently report high non-audit fees. In contrast, in the year after fees disclosure, the earnings response coefficient of firms with higher non-audit fees is lower than those with lower non-audit fees. Both Krishnan et al. (2005) and Francis and Ke (2006) believe that their results provide evidence that investors perceive higher non-audit fees as impairing auditor independence.

Gaynor, McDaniel, and Neal (2006) examine the effect of mandatory disclosure requirement of APNAS on the decision of audit committees to use APNAS. Based on experimental research with 100 corporate directors, they find that audit committees are more likely to recommend the joint provision if it improves audit quality. However, the authors also find that public disclosure lowers the likelihood of audit committees in approving the joint provision, even when they believe that the joint provision may improve audit quality.

Maydew and Shackelford (2007) examine the influence of accounting events such as accounting scandals, the passage of the Sarbanes-Oxley Act, and SEC and PCAOB's regulatory actions on the changing role of auditors in corporate tax planning. Using a sample of 248 S\&P 500 companies as at 31 December 2003, they find that the companies pay their auditor a similar amount of fees for audit and for tax work in the year 2001. However, in the year 2003, the amount paid to audit work was twice than for tax work and in 2004 four times. Nevertheless, the 
tax practices of the large accounting firms remained stable and therefore there was a shift in the client base.

The above studies all relate to APNAS but the following two studies specifically relate to APTS. Cook et al. (2008), using a sample of 1,802 firm-year observations on U.S. firms during the period 2000 - 2004, find that APTS fees are associated with greater reductions in third to fourth quarters effective tax rates (ETRs) for companies that would miss consensus earnings forecasts in the absence of tax expense management. Further, they also find that among companies that do not purchase APTS, for those that would miss consensus earnings forecasts absent ETR changes, the ETR decreases are larger than for other companies. Furthermore, the authors find that APTS fees are associated with larger third to fourth quarter ETR decreases in both pre- and post- SOX periods.

McGuire et al. (2012) examine the relationship between auditor tax-specific industry expertise and company tax avoidance. They use data on 2,513 companies during the period $2002-2009$. The authors find that companies that purchase tax services from a tax expert auditor engage in greater tax avoidance. Furthermore, they find that overall expertise (tax and audit expert) of auditors is related to greater tax avoidance. They argue that this result indicates that auditors with overall expertise are capable of combining their audit and tax expertise to develop tax strategies that benefit clients from both tax and financial statement perspectives.

The concern expressed by Barbara Roper, Consumer Federation of America, at the PCAOB's roundtable on impairment of auditor independence as a consequence of APTS, exemplifies the issue: 
"Just back to the issue of opinion shopping. I think the key -because we're talking about auditor independence here and not auditor efficiency -- is, if you get that advice, that aggressive recommendation, from the tax department of the audit firm, how likely is the auditor to call that advice into question? and he or she significantly less likely to call that advice into question than they would be if the advice came from a third party? and so this idea that there's a special risk to going outside to third parties to -- and you'll get aggressive recommendations, I don't think -- I don't think past experience necessarily bears that out, in terms of the-- some of the recent scandals, but also that the question is, When push comes to shove, will the auditor call that recommendation into question? and I think that becomes significantly less likely if the recommendation came from his own firm." (PCAOB 2004, 79)

\subsubsection{Literature Review on Income Shifting}

Collins et al. (1998) examine the extent of income shifting by U.S. multinationals. Using data on 577 manufacturing companies during the period 1984 - 1992, they find that for U.S. multinationals that face higher average foreign tax rates compared to the U.S. tax rate there is stronger evidence of taxmotivated income shifting. They estimate that these multinationals shift approximately $\$ 25-30$ million of income per company to the U.S each year. For the full sample, this equals a total transfer of approximately $\$ 34-40$ billion of income to the U.S. The authors also test how investors perceive the shifted income. As per their expectation, they find that investors recognize the effects of income shifting on their valuations.

Rego (2003) examines the effect of firm characteristics such as size, profitability, and extent of operations, on tax avoidance activities. Using data on 5,379 U.S. domestic and multinational companies during period $1990-1997$, the author finds that larger firms, both for the full sample and for just U.S. multinationals, have higher worldwide ETRs than smaller firms. Rego (2003) argues that it supports the argument that larger firms face political costs which 
limit their tax avoidance activities. Further, Rego (2003) finds, for the full sample, that firms with higher income have lower worldwide ETRs. Specifically for U.S. multinationals, Rego (2003) finds that worldwide ETRs are decreasing in both U.S. and foreign pre-tax income. The author also finds that multinationals with a higher proportion of foreign operations have lower worldwide and foreign ETRs. These results support the argument that economies of scale plays a significant role in tax planning.

Clausing (2009) examines the relationship between the profit rates of U.S. affiliates and foreign country tax rates and also the influence of income taxes on U.S. multinationals' real operations. Using data on tax and the operations of U.S. multinationals in approximately 60 countries during the period $1982-2004$, the author finds that a 1 percentage point lower tax rate in a host country compared to the U.S. is related to a 0.5 percentage point higher profit rate for affiliates based in that host country. The author estimates that by 2004 , there was more than $\$ 180$ billion of corporate income shifted out of the U.S. In terms of real impact, the author estimates that a 1 percentage point reduction in the tax rate difference would increase employment by $1.6 \%$. The results indicate that employment-based tax responses result in approximately $\$ 80$ billion lower U.S. profits and about $15 \%$ lower U.S. government corporate tax revenues.

Klassen and Laplante (2012a) examine the extent of multijurisdictional income shifting by U.S. multinationals. Further, they also examine whether income shifting has changed over time. Using 8,074 firm-year observations on U.S. companies over the period 1988 - 2009, the authors find that U.S. companies have become more active in income shifting to foreign jurisdictions. Holding tax 
rate differences between U.S. and foreign jurisdictions constant, they estimate that among 380 corporations with low average foreign tax rates shifted approximately $\$ 10$ billion of additional income out of the United States annually during 20052009 relative to $1998-2002$. Further, they find that firms with low average foreign tax rates shifted income more aggressively out of the U.S. following declining IRS audit intensity, a beneficial U.S. tax law change, and a marked increase in non-U.S. transfer pricing enforcement activities.

Klassen and Laplante (2012b), using data on 3,829 firm-year observations on U.S. multinationals during the period 1993 - 2006, test whether foreign reinvestment-related incentives influence income shifting by multinationals and whether financial reporting incentives influence income shifting behaviour. They find that firms with low foreign tax rates relative to domestic tax rates shift significantly more income from U.S. to foreign jurisdictions when foreign reinvestment-related incentives are high. Further, they find that more aggressive financial reporting firms and those that report lower tax expense by designating earnings outside the U.S as permanently reinvested, are more responsive to income shifting incentives than other firms even after controlling for reinvestment incentives. This shows that firms with greater financial reporting incentives shift more income out of the U.S.

Dharmapala and Riedel (2013) investigate the income shifting behaviour of multinational companies. Using data on 1,806 subsidiary companies operating in EU-25 countries, except Cyprus, Malta, and Slovenia, the authors find that positive earnings shocks for the parent companies are more strongly related to the increase in pre-tax income of subsidiaries in low-tax countries compared to the 
pre-tax income of high-tax affiliates. They find that the estimated effect is mostly related to the strategic use of debt across affiliates.

Dyreng and Markle (2016) examine the influence of financial constraints on income shifting. Using data on 2,058 U.S. multinationals over the period $1998-$ 2011, the authors find that financially constrained firms shift less income from the U.S. to foreign countries than do their unconstrained peers. They estimate that financially constrained firms shift out $20 \%$ less of pre-shifted income than do unconstrained firms. In dollar term, the mean (median) constrained firm shifts $\$ 16$ million (\$7 million) out of the U.S. each year, while the mean (median) unconstrained firm shifts \$321 million (\$134 million) out of the U.S. each year.

\subsubsection{Hypotheses Development}

Overall assessment of the studies reviewed above suggests that the joint provision of audit and non-audit services improves auditor understanding of their clients, that is provide knowledge spillover effect (Simunic, 1984) and (Antle et al., 2006), thereby increasing the quality of both audit and non-audit work. In addition, overall, the results from these studies indicate that appointment as a tax consultant does not impair auditor independence. Hence, APTS are likely to be negatively related to income shifting behaviour. On the other hand, if it is accepted that auditors are more likely to accommodate managers' behaviour due to their economic bonding to the client, APTS will be positively related to income shifting activities.

Given those two contrasting views regarding the effect of APTS on income shifting, this study tests the following hypotheses: 
H1(a): The joint provision of audit and tax services by auditors has a negative association with income shifting behaviour of U.S. multinationals.

H1(b): The joint provision of audit and tax services by auditors has a positive association with income shifting behaviour of U.S. multinationals.

\subsection{Research Design}

Section 2.3.1 discusses the income shifting measurement model used to test the hypotheses. Section 2.3.2 explains the construction of the sample.

\subsubsection{Measuring Income Shifting}

There are at least three basic approaches used in empirical studies to estimate income shifting. The first model is Hines and Rice (1994) which relies on the argument that pre-shifted income in a jurisdiction varies with the jurisdiction's labor, capital, and productivity inputs in a Cobb-Douglas production function. The authors infer income shifting from the movement of income incremental to those inputs factors. As argued by Dyreng and Markle (2016), adaptation of this model at firm-level is challenging as the model is developed for analysis at the jurisdiction level.

Second, the model developed by Collins et al. (1998) which infers income shifting from the co-movement of the rate of return on foreign sales with the rate of return on worldwide sales. Based on this, the authors find that for U.S. multinationals that face average foreign tax rates higher than the U.S. tax rate there is evidence of tax-motivated income shifting. However, Dyreng and Markle (2016) argue that the Collins et al. (1998) approach focussed on net shifting which would reflect the sources of noise affecting estimate of inbound income shifting. 
Given the limitations cited above, this study uses the income shifting model developed by Dyreng and Markle (2016) which enables the separation of inbound income shifting and outbound income shifting. The model is developed as follows:

$$
\begin{array}{ll}
\text { PIFO } * & =\text { SALEFO }- \text { EXPFO } \\
\text { PIDOM }^{*}=\text { SALEDOM }- \text { EXPDOM }
\end{array}
$$

where:

PIFO* : unobservable pre-transfer foreign pre-tax earnings.

PIDOM* $^{*} \quad$ : unobservable pre-transfer domestic pre-tax earnings.

SALEFO : foreign sales to third parties.

SALEDOM : domestic sales to third parties.

EXPFO : expenses incurred to generate foreign income from foreign sales to third parties.

EXPDOM : expenses incurred to generate domestic income from domestic sales to third parties.

Equations (2.1a) and (2.1b) can be rewritten as follows:

$$
\begin{array}{ll}
\text { PIFO }^{*} & =\rho_{f} \text { SALEFO } \\
\text { PIDOM }^{*} & =\rho_{d} \text { SALEDOM }
\end{array}
$$

where:

$\rho_{\mathrm{f}}:$ return on sales for pre-transfer foreign pre-tax income.

$\rho_{d}:$ return on sales for pre-transfer domestic pre-tax income.

To estimate the amount of income shifted, equations (2.2a) and (2.2b) are modified as follows:

$$
\mathrm{PIFO}=(1-\gamma) \rho_{\mathrm{f}} \mathrm{SALEFO}+\theta \rho_{d} \mathrm{SALEDOM}
$$


$\mathrm{PIDOM}=\gamma \rho_{\mathrm{f}} \mathrm{SALEFO}+(1-\theta) \rho_{d} \mathrm{SALEDOM}$

where:

PIFO : reported post-transfer foreign pre-tax earnings.

PIDOM : reported post-transfer domestic pre-tax earnings.

$\theta \quad:$ the fraction of pre-transfer domestic pre-tax earnings that is transferred to reported foreign pre-tax earnings or outbound shifting.

$\gamma \quad:$ the fraction of pre-transfer foreign pre-tax earnings that is transferred to reported domestic pre-tax earnings or inbound shifting.

Accordingly, equation (2.3a) states that reported pre-tax foreign earnings is the sum of foreign pre-tax earnings not transferred plus pre-tax domestic earnings transferred and equation (2.3b) states that reported pre-tax domestic earnings is the sum of transferred foreign pre-tax earnings plus not transferred domestic pretax earnings.

In the spirit of Dharmapala and Riedel (2013) who use earnings shocks to identify income shifting, Dyreng and Markle (2016) modify equations (2.3a) and (2.3b) by restating the variables in change form and by including intercept and error terms. They argue that although the modification uses changes in both sales and income, the parameters generated do not represent changes in income transfers or changes in return on sales. The parameters generated from the equations should be interpreted as the marginal returns on sales, $\rho_{f}$ and $\rho \mathrm{d}$, and the fractions of the shock to income that is transferred, $\theta$ and $\gamma$. The modified equations are: 


$$
\begin{aligned}
& \Delta \mathrm{PIFO}_{j, t}=\alpha_{o}+(1-\gamma) \rho_{\mathrm{f}} \Delta \mathrm{SALEFO}_{j, t}+\theta \rho_{d} \Delta \mathrm{SALEDOM}_{j, t}+\tilde{\mathrm{e}}_{j, t} \\
& \triangle P I D O M_{j, t}=\beta_{o}+\gamma \rho_{f} \Delta S A L E F O_{j, t}+(1-\theta) \rho_{d} \Delta S A L E D O M_{j, t}+\mathrm{u}_{j, t}
\end{aligned}
$$

where:

$\triangle \mathrm{PIFO}_{\mathrm{j}, \mathrm{t}} \quad:$ foreign pre-tax earnings in year $\mathrm{t}$ less foreign pre-tax earnings in year $\mathrm{t}-1$, scaled by total assets in year $\mathrm{t}-1$ of firm $j$.

$\triangle \mathrm{PIDOM}_{\mathrm{j}, \mathrm{t}} \quad$ : domestic pre-tax earnings in year $\mathrm{t}$ less domestic pre-tax earnings in year $\mathrm{t}-1$, scaled by total assets in year $\mathrm{t}-1$ of firm j.

$\triangle \mathrm{SALEFO}_{\mathrm{j}, \mathrm{t}} \quad$ : foreign sales in year $\mathrm{t}$ less foreign sales in year $\mathrm{t}-1$, scaled by total assets in year $\mathrm{t}-1$ of firm $\mathrm{j}$.

$\triangle$ SALEDOM $_{\mathrm{j}, \mathrm{t}} \quad$ : domestic sales in year $\mathrm{t}$ less domestic sales in year $\mathrm{t}-1$, scaled by total assets in year $\mathrm{t}-1$ of firm $\mathrm{j}$.

This study focuses on the outbound transfer parameter $(\theta)$, rather than the inbound transfer parameter $(\gamma)$. As Dyreng and Markle (2016) note, there are several reasons for doing that. First, the tax rules on arm's length transfer pricing require companies to transfer their income toward the location in which economic value is added and prior research shows that more than two-thirds of value added of U.S. multinationals is in the U.S (Barefoot and Mataloni 2011). Second, inbound income transfers include the sales made through directly owned foreign branches and also exports of goods directly to foreign customers. Consequently, the inbound transfer parameter contains noise from these sources which could mislead its interpretation. 
To include the effect of APTS to test the hypotheses, the inbound and outbound income shifting parameters are written as follows:

$$
\begin{aligned}
& \theta=\theta_{0}+\theta_{1} X \\
& \gamma=\gamma_{0}+\gamma_{1} X
\end{aligned}
$$

where:

X : is a measure of APTS (in Dyreng and Markle (2016), it is a measure of financial constraints.

$\theta_{0} \quad$ : base outbound transfer.

$\gamma_{0} \quad$ : base inbound transfer.

$\theta_{1} \quad$ incremental effect of APTS on outbound transfer.

$\gamma_{1} \quad$ : incremental effect of APTS on inbound transfer.

Furthermore, the parameters for return on sales can be written as follows:

$$
\begin{aligned}
& \rho_{f}=\rho_{f 0}+\rho_{f 1} \mathrm{X}+\sum_{c} \rho_{f c} C \\
& \rho_{\mathrm{d}}=\rho_{\mathrm{d} 0}+\rho_{\mathrm{d} 1} \mathrm{X}+\sum_{c} \rho_{d c} C
\end{aligned}
$$

where:

$\rho_{f 0} \quad$ : base return on sales for pre-transfer foreign pre-tax earnings income.

$\rho_{\mathrm{d} 0} \quad$ : base return on sales for pre-transfer domestic pre-tax income.

$\rho_{f 1}$ : incremental effect of APTS on the return on sales for pre-transfer foreign pre-tax income.

@d1 : incremental effect of APTS on the return on sales for pre-transfer domestic pre-tax income.

$\rho_{f c} \quad$ incremental effect of control variables on the return on sales for pretransfer foreign pre-tax income. 
$\rho_{\mathrm{dc}} \quad$ : incremental effect of control variables on the return on sales for pretransfer domestic pre-tax income.

C : vector of control variables.

The estimation equations are then formed by substituting of equations (2.5a), (2.5b), (2.5c), and (2.5d) in equations (2.4a) and (2.4b):

$$
\begin{gathered}
\Delta P I F O=\alpha_{0}+\left(1-\left[\gamma_{0}+\gamma_{1} X\right]\right)\left[\rho_{f 0}+\rho_{f 1} X+\sum_{c} \rho_{f c} C_{c}\right] \Delta S A L E F O+ \\
{\left[\theta_{0}+\quad \theta_{1} X\right]\left[\rho_{d 0}+\rho_{d 1} X+\sum_{c} \rho_{d c} C_{c}\right] \Delta S A L E D O M+\varepsilon}
\end{gathered}
$$

$$
\begin{aligned}
& \Delta P I D O M=\beta_{0}+\left[\gamma_{0}+\gamma_{1} X\right]\left[\rho_{f 0}+\rho_{f 1} X+\sum_{c} p_{f c} C_{c}\right] \Delta S A L E F O+ \\
& \left(1-\left[\theta_{0}+\quad \theta_{1} X\right]\right)\left[\rho_{d 0}+\rho_{d 1} X+\sum_{c} \rho_{d c} C_{c}\right] \Delta S A L E D O M+u
\end{aligned}
$$

Equations (2.6a) and (2.6b) are estimated by seemingly unrelated regression (SUR) 3 as this allows estimation of the shifting and returns parameters with associated test statistics in a single-stage estimation. As a consequence, the parameters are estimated based on the conditions applying in both equations of the model. H1(a) will be supported if $\theta_{1}$ is found to be negative, while H1(b) will be supported if $\theta_{1}$ is found to be positive.

\footnotetext{
3 Seemingly unrelated regression (SUR) deals with estimation of several equations as a set. The equations each have their own dependent variable but potentially different sets of explanatory variables. Each equation is a valid linear regression on its own but the error terms are assumed to be correlated across the equations. Each equation could be estimated by OLS. However, while the estimates would be consistent, they would not be as efficient as obtained by the SUR method. SUR is identical to OLS if either the errors are in fact uncorrelated or the regressors are all the same.
} 
Following Krishnan and Visvanathan (2011), this study measures APTS as tax fees paid (in thousand dollars) scaled by the square root of total assets (TAXFEES). As bigger firms are more likely to pay higher tax fees, by deflating tax fees with total assets, this study mitigates the possibility that the result generated from estimating equations (2.6a) and (2.6b) is just a reflection of the size effect. For example, bigger firms may shift their income more than smaller firms since they have the resources to do so.

To control for the effect of firm-level characteristics that may influence the return on sales parameters which would then lower the ability to effectively observe the income shifting parameters, this study includes worldwide return on sales (WWROS) to control for the overall profitability that is unaffected by income shifting, the ratio of cash to total assets $(C T A)$ to control the possibility that firms with significant cash holdings may have different rates of returns due to favourable cost of financing, log of total assets (LNTA) to control the effect of size on the rates of returns, and the ratio of intangible to total assets (ITA) to control for profitability differences that may be related to the firms' assets intangibility.

Furthermore, this study also includes as control variables the ratio of foreign sales to total sales (FTS) to control for the possibility multinationals may enjoy systematically different rates of profitability on domestic and foreign sales, the ratio of debt to total assets (DTA) to control for the possibility that firms with higher leverage have higher financial sophistication which then influences rates of returns, $\mathrm{R} \& \mathrm{D}$ expense $(R \& D E X P)$ to control the effects of $\mathrm{R} \& \mathrm{D}$ expense tax treatment, and advertising expense (ADVEXP) to control the effects of advertising expense on return on sales. These control variables are similar to those used in 
Dyreng and Markle (2016). In Appendix 1, this study provides detailed definitions of the measures of all the variables used in the study.

\subsubsection{Sample}

The sample for this study consists of observations on U.S. multinationals between the years 2002 - 2015 for which the data is available at the Compustat database. This study then merges that data with audit fees information available in the Audit Analytics database. The sample period begins in 2002 because tax fees disclosures were limited prior to that year. The sample ends in the year 2015 to mitigate the possibility that multinationals alter their income shifting behaviour due to the 2016 presidential campaign where both candidates raised the issue of reform of business taxation.

Table 2. 1. Sample Selection - APTS and Income Shifting

\begin{tabular}{|c|c|c|}
\hline Criteria & Firms & Firm-Year \\
\hline $\begin{array}{l}\text { U.S. multinational firms with available information on audit } \\
\text { fees during the period } 2002-2015 \text { with foreign and } \\
\text { domestic sales summing to within } 1 \text { percent of total sales, } \\
\text { foreign and domestic pre-tax income summing to within } 1 \\
\text { percent of total pre-tax income, firms with domestic sales } \\
\text { and foreign sales both more than } \$ 1 \text { million. }\end{array}$ & 3,723 & 26,023 \\
\hline $\begin{array}{l}\text { Less regulated firms (SIC } 4900-4999 \text {, SIC } 6000-6999 \text { ) } \\
\text { and flow-through tax entities. }\end{array}$ & 3,461 & 24,308 \\
\hline $\begin{array}{l}\text { Less firms with assets in current and previous year less than } \\
\$ 1 \text { million and firms with special items more than } 10 \% \text { of } \\
\text { sales }\end{array}$ & 3,448 & 24,018 \\
\hline $\begin{array}{l}\text { Less firms with missing data necessary to calculate the } \\
\text { variables used to test the hypotheses, firms with zero tax } \\
\text { fees, and observations with Cook's Distance score in the } \\
\text { top } 2 \% \text {. }\end{array}$ & 1,762 & 10,248 \\
\hline
\end{tabular}

This study eliminates observations with foreign and domestic sales values less than $\$ 1$ million. To ensure that companies with high intra-company transactions are deleted, observations are dropped if the sum of foreign and 
domestic sales is not within $1 \%$ of total sales or the sum of foreign and domestic pre-tax income is not within $1 \%$ of total pre-tax income. As in Dyreng and Markle (2016), this study drops regulated utility and financial companies and flowthrough tax entities. To delete very small multinationals, this study drops companies with current and previous total assets less than $\$ 1$ million. Furthermore, companies with special items more than $10 \%$ of revenue are also dropped to ensure that most of the multinational's pre-tax earnings result from transactions with third-party customers.

To make sure that the result is not driven by just a few influential observations, this study eliminates any observations with a Cook's Distance score in the top $2 \%$ of the sample for each test model, similar to Dyreng and Markle (2016). Cook's Distance is chosen as the elimination tool as it is a multivariate measure and this study, therefore, deletes extreme observations based on the interrelationships of all variables included in the estimation model.

Following previous literature Dyreng, Hanlon, and Maydew (2008) and Dyreng et al. (2010), this study sets the value of research and development expenses and advertising expenses to 0 if the data for those expenses are missing from the Compustat database. To mitigate the possibility that U.S. multinationals have zero tax fees due to hiring tax specialists other than their auditors, this study deletes observations with zero APTS fees. In other words, this study examines the influence of APTS on income shifting conditional on the firms purchasing tax services from their auditors. This study summarises the sample selection process in Table 2.1. 


\subsection{Empirical Results: Auditor Provided Tax Services and Income Shifting}

This section presents the findings on the influence of the APTS on income shifting. Section 2.4.1 reports the descriptive statistics of the sample including the correlations among the test variables. In section 2.4 .2 , this study reports the baseline result. In Section 2.4.3, this study reports the results of addressing potential endogeneity. Section 2.4.4 gives the results for robustness tests.

\subsubsection{Descriptive Statistics}

Table 2.2 shows the descriptive statistics of the sample. The mean (median) value of $\triangle \mathrm{PIFO}$ is $0.4 \%(0.2 \%)$; the mean (median) value of $\triangle \mathrm{PIDOM}$ is $0.05 \%$ $(0.05 \%)$; the mean (median) value of $\triangle \mathrm{SALEFO}$ is $3.3 \%(2.1 \%)$; the mean (median) value of $\triangle \mathrm{SALEDOM}$ is $3.3 \%$ (2\%); The mean (median) value of APTS measure, TAXFEES, is 10.61 (6.792); the mean (median) value of WWROS is $6 \%(6.8 \%)$; the mean (median) value of $R \& D E X P$ is $6 \%(1.9 \%)$; the mean (median) value of $A D V E X P$ is $1.1 \%(0 \%)$; the mean (median) value of FTS is $41.5 \%$ (40.4\%); the mean (median) value of $C T A$ is $13.4 \%(10.3 \%)$; the mean (median) value of DTA is $17.1 \%(14.6 \%)$; the mean (median) value of ITA is $22 \%$ (18\%); the mean (median) value of $M E R G E$ is 0.526 (1); the mean (median) value of $N O L$ is 0.633 (1); the mean (median) value of CAPINT is $20.9 \%$ (15.9\%); the mean (median) value of $A U D I N D E P$ is $10.6 \%$ (4.5\%); the mean (median) value of LEVERAGE is $38 \%$ (15.3\%); the mean (median) value of AUDFEES is 14.46 (14.46); and the mean value of LNTA is 7.160 which is the same as the median value (7.160).

In Appendix 2, this study provides the correlation matrix for all of the variables used in the study. The pairwise correlations are broadly consistent with 
expectations but individual values are of limited significance as the association of APTS with income shifting is tested in a multivariate context. Importantly, the correlations are not indicative of multicollinearity being a problem for estimation of the test model.

Table 2. 2. Descriptive Statistics - APTS and Income Shifting

This table shows the descriptive statistics of 10,248 U.S. multinationals for period $2002-$ 2015 in the sample. Appendix 1 provides a detailed description of the variables.

\begin{tabular}{lcccccccc}
\hline Variable & $\mathrm{N}$ & Mean & Median & STD & Min & P25 & P75 & Max \\
\hline$\Delta$ PIFO & 10,248 & 0.004 & 0.002 & 0.033 & -0.211 & -0.006 & 0.014 & 0.290 \\
$\Delta$ PIDOM & 10,248 & 0.005 & 0.005 & 0.075 & -0.468 & -0.019 & 0.029 & 0.586 \\
$\Delta$ SALEFO & 10,248 & 0.033 & 0.021 & 0.111 & -1.005 & -0.007 & 0.066 & 1.048 \\
$\Delta$ SALEDOM & 10,248 & 0.033 & 0.020 & 0.149 & -1.397 & -0.016 & 0.074 & 3.057 \\
TAXFEES & 10,248 & 10.61 & 6.792 & 12.29 & 0.001 & 2.441 & 14.21 & 141.9 \\
ATS & 10,248 & 0.499 & 0.000 & 0.500 & 0.000 & 0.000 & 1.000 & 1.000 \\
WWROS & 10,248 & 0.060 & 0.068 & 0.140 & -0.531 & 0.013 & 0.129 & 0.404 \\
R\&DEXP & 10,248 & 0.060 & 0.019 & 0.084 & 0.000 & 0.000 & 0.092 & 0.381 \\
ADVEXP & 10,248 & 0.011 & 0.000 & 0.025 & 0.000 & 0.000 & 0.008 & 0.148 \\
FTS & 10,248 & 0.415 & 0.404 & 0.229 & 0.020 & 0.231 & 0.578 & 0.950 \\
CTA & 10,248 & 0.134 & 0.103 & 0.115 & 0.003 & 0.048 & 0.188 & 0.535 \\
DTA & 10,248 & 0.171 & 0.146 & 0.167 & 0.000 & 0.008 & 0.267 & 0.744 \\
LNTA & 10,248 & 7.160 & 7.160 & 1.773 & 3.133 & 5.971 & 8.339 & 11.43 \\
ITA & 10,248 & 0.220 & 0.180 & 0.186 & 0.000 & 0.061 & 0.342 & 0.736 \\
MERGER & 10,248 & 0.526 & 1.000 & 0.499 & 0.000 & 0.000 & 1.000 & 1.000 \\
NOL & 10,248 & 0.633 & 1.000 & 0.482 & 0.000 & 0.000 & 1.000 & 1.000 \\
CAPINT & 10,248 & 0.209 & 0.159 & 0.178 & 0.015 & 0.082 & 0.276 & 0.870 \\
INSTOWN & 10,248 & 0.485 & 0.489 & 0.281 & 0.000 & 0.233 & 0.725 & 0.951 \\
AUDINDEP & 10,248 & 0.106 & 0.045 & 0.169 & 0.000 & 0.008 & 0.122 & 0.988 \\
AUDTENURE & 10,248 & 12.78 & 10.00 & 9.821 & 1.000 & 5.000 & 17.00 & 40.00 \\
LEVERAGE & 10,248 & 0.380 & 0.153 & 0.818 & 0.000 & 0.024 & 0.362 & 6.124 \\
AUDFEES & 10,248 & 14.46 & 14.46 & 1.077 & 11.86 & 13.80 & 15.17 & 17.14 \\
AUDCHANGE & 10,248 & 0.045 & 0.000 & 0.207 & 0.000 & 0.000 & 0.000 & 1.000 \\
\hline & & & & & & & &
\end{tabular}

\subsubsection{Baseline Result}

Table 2.3 presents the result when the equations (2.6a) and (2.6b) are estimated using SUR. Column 1 shows the result when those equations are estimated without the inclusion of any test or control variables and the estimates are thus the unconditional means effect of the parameters. The results show that 
on average, U.S. multinationals shift 5.1\% (significant at 5\% level) of their pretransfer domestic pre-tax income into foreign pre-tax earnings.

Furthermore, Column 1 shows that U.S. multinationals in the sample shift approximately $42.2 \%$ of their pre-transfer foreign pre-tax income to the U.S. The inbound shifting parameter, as expected, is higher than the outbound shifting parameter since the inbound shifting parameter contains severe noise, as explained above. For the return on sales parameters, Column 1 indicates that U.S. multinationals have a higher on sales return in foreign jurisdictions.

\section{Table 2. 3. Baseline Result - APTS and Income Shifting}

This table shows the results for the impact of auditor provided tax services on income shifting. Column 1 shows the result for the model without TAXFEES and the control variables. Column 2 shows the results when TAXFEES and the control variables on the return on sales parameters are included. The p-values are shown in brackets. Standard errors are clustered at the firm and year level. All continuous variables are mean centered. Definitions of variables are given in Appendix 1.*,**, and ***, indicate statistical significance at the 10,5 , and 1 percent levels, respectively.

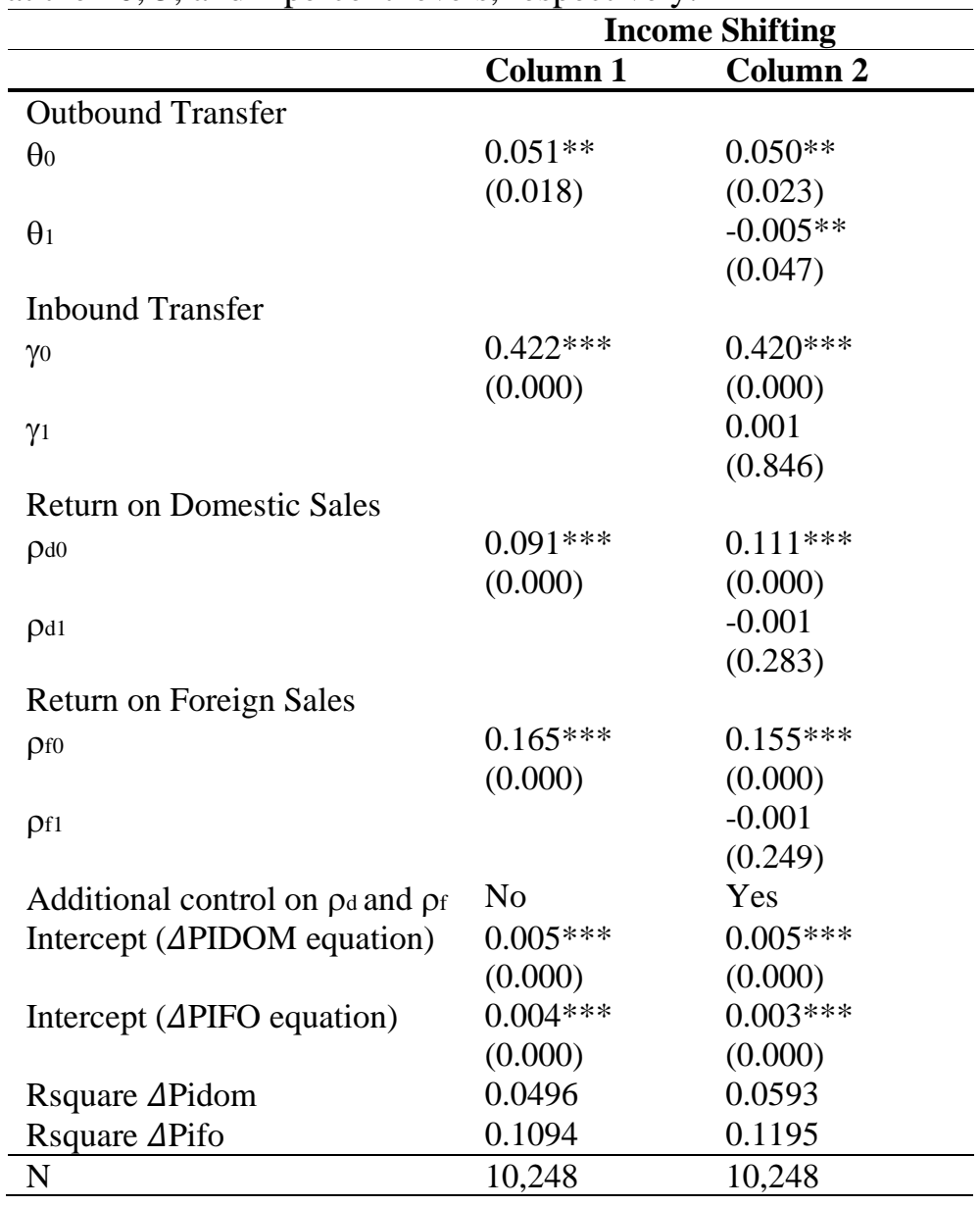


Column 2 of Table 2.3 shows the results when TAXFEES and the control variables on the return on sales parameters are included to estimate equations (2.6a) and (2.6b). The results show that the parameter of APTS on outbound shifting $\left(\theta_{1}\right)$ is -0.005 , and significant at the $5 \%$ level. This shows that U.S. multinationals with a higher level of TAXFEES have lower outbound income shifting activities compared to those with a lower level of TAXFEES. The result presented in Table 2.3, therefore, supports the hypothesis H1(a) that APTS are negatively related to outbound income shifting. This evidence supports the argument that APTS limit the motivation of managers to engage in income shifting behaviour and thus rejects impairment of auditor independence. However, the estimate of the incremental impact of APTS on inbound shifting, $\gamma_{1}$, is not significant. Similarly, the incremental effect for APTS on the return on sales for both domestic and foreign sales are not significant.

\subsubsection{Endogeneity Test}

This section performs a test to address potential endogeneity in respect of firms' decision to purchase tax services from auditors. Previous studies find that the decision to purchase tax services from auditors is a deliberate decision and driven by several factors (see, for example, Omer, Bedard, and Falsetta (2006), Lassila, Omer, Shelley, and Smith (2010), McGuire et al. (2012), Krishnan and Visvanathan (2011), Krishnan et al. (2013), and Gleason et al. (2018)). The potential endogeneity is addressed using a two-stage model (Heckman, 1979). In the first-stage, involves estimation of the following probit regression model: 


$$
\begin{aligned}
\operatorname{Prob}\left(\text { ATS }_{j, t}\right) & =\alpha+\beta_{1} \text { MERGER }_{j, t}+\beta_{2} \text { NOL }_{j, t} \\
& +\beta_{3} \text { CAPINT }_{j, t}+\beta_{4} \text { INSTOWN }_{j, t} \\
& +\beta_{5} \text { AUDINDEP }_{j, t}+\beta_{6} \text { AUDTENURE }_{j, t} \\
& +\beta_{7} \text { LEVERAGE }_{j, t}+\beta_{8} \text { AUDFEES }_{j, t} \\
& +\beta_{9} \text { AUDCHANGE }_{j, t}+\beta_{10} \text { WWROS }_{j, t} \\
& +\beta_{11} \text { FTS }_{j, t}+\beta_{12} \text { CTA }_{j, t}+\beta_{13} D T A_{j, t} \\
& +\beta_{14} \text { LNTA }_{j, t}+\beta_{15} \text { ITA }_{j, t}+\beta_{16} \text { R\&DEXP }_{j, t}+\beta_{17} A D V E X P_{j, t} \\
& +\beta_{18} \text { INDUSTRYDUMMY }_{1}+\beta_{19} \text { YEARDUMMY } \\
& +\mathrm{e}_{j, t}
\end{aligned}
$$

Following Gleason et al. (2018), ATS is an indicator variable equal to one if a firm's auditor tax fee is above the yearly median of sample firms and 0 otherwise. Similar to McGuire et al. (2012) and Gleason et al. (2018), Several exclusionary variables are included: MERGER, an indicator variable coded one if there is merger activity; NOL, a dummy variable coded one if there is a tax loss carry forward; CAPINT, the ratio of net property, plant, and equipment to total assets in previous year; INSTOWN, the average of institutional ownership during the year;4 $A U D I N D E P$, the ratio of non-audit fees to audit fees; AUDTENURE, the number of years the auditor has served the company; LEVERAGE, sum of the book value of short-term and long-term debt deflated by the book value of equity; AUDFEES, natural logarithm of audit fees; AUDCHANGE, a dummy variable equal to one if the firm changed the auditor from the prior year. In addition, the control variables used in estimation of equations (2.6a) and (2.6b) are also included. The inverse Mills ratio generated from the first-stage regression is then included in the estimation of equations (2.6a) and (2.6b). Appendix 1 provides detailed definitions of the measures used for all the variables.

4 This study uses the average of institutional ownership instead of the percentage of institutional ownership at the beginning year as in Gleason et al. (2018) because of the possibility that the decision to purchase tax services from the incumbent auditor may occur during the year. 
The result of estimating the equation (2.7) is presented in Table 2.4. Column 1 shows the result when only exclusionary variables are included as in previous studies (McGuire et al. (2012) and Gleason et al. (2018)). The results show that the decision to purchase tax services from auditors, ATS, is significant and positively related to INSTOWN, AUDINDEP, AUDFEES, and AUDTENURE, while it is significant and negatively related to LEVERAGE and AUDCHANGE. Column 2 shows the results of estimating the full model where all the control variables are included. The results show that the probability to purchase tax service from auditors, ATS, is significant and positively related to INSTOWN, AUDINDEP, AUDTENURE, AUDFEES, FTS, CTA, DTA, LNTA, and ITA, whereas it is significant and negatively related to LEVERAGE, AUDCHANGE, and $R \& D E X P$.

Column 2 of Table 2.4 shows that the probability of firms hiring their auditor as a tax consultant is lower when they have higher $R \& D$ expense. This may be related to the advantageous tax treatment effect of that expense. Consequently, U.S. multinationals can substitute for the tax benefits from using tax consultant by R\&D expense. Importantly, the probability of hiring auditors as tax consultants is positively related to the auditor independence from the client, AUDINDEP. This may indicate that the decision to purchase tax services from auditors does not impair the independence of auditors, which supports the baseline result. Further, the selection score (area under the ROC Curve) for the full model is 0.8200 which suggest that the selection model has excellent discriminatory power. 
Table 2. 4. First-Stage Model - APTS and Income Shifting

This table shows the regression result for the first-stage regression for the base and full models. Continuous variables are winsorized at the 1 and 99 percent levels. The p-values are shown in brackets. Appendix 1 provides definitions of the variables. *, **, and ***, indicate statistical significance at the 10,5 , and 1 percent level, respectively.

\begin{tabular}{|c|c|c|}
\hline & \multicolumn{2}{|c|}{ ATS } \\
\hline & Column 1 & Column 2 \\
\hline \multirow[t]{2}{*}{ MERGER $\mathrm{t}$} & 0.015 & -0.042 \\
\hline & $(0.602)$ & $(0.174)$ \\
\hline \multirow[t]{2}{*}{$\mathrm{NOL}_{t}$} & -0.049 & -0.049 \\
\hline & $(0.106)$ & $(0.112)$ \\
\hline \multirow[t]{2}{*}{ CAPINT $_{t}$} & 0.178 & 0.059 \\
\hline & $(0.104)$ & $(0.649)$ \\
\hline \multirow[t]{2}{*}{ INSTOWN $_{\mathrm{t}}$} & $0.507 * * *$ & $0.364 * * *$ \\
\hline & $(0.000)$ & $(0.000)$ \\
\hline \multirow[t]{2}{*}{ AUDINDEP $\mathrm{t}$} & $0.421 * * *$ & $0.219 * *$ \\
\hline & $(0.000)$ & $(0.018)$ \\
\hline \multirow[t]{2}{*}{ AUDTENURE $_{t}$} & $0.012 * * *$ & $0.010 * * *$ \\
\hline & $(0.000)$ & $(0.000)$ \\
\hline \multirow[t]{2}{*}{ LEVERAGE $_{t}$} & $-0.046 * *$ & $-0.066 * * *$ \\
\hline & $(0.015)$ & $(0.003)$ \\
\hline \multirow[t]{2}{*}{ AUDFEES $_{\mathrm{t}}$} & $0.750 * * *$ & $0.454 * * *$ \\
\hline & $(0.000)$ & $(0.000)$ \\
\hline \multirow[t]{2}{*}{ AUDCHANGEt $_{t}$} & $-0.153 * *$ & $-0.142 *$ \\
\hline & $(0.041)$ & $(0.060)$ \\
\hline \multirow[t]{2}{*}{$\mathrm{WWROS}_{\mathrm{t}}$} & & 0.107 \\
\hline & & $(0.393)$ \\
\hline \multirow[t]{2}{*}{$\mathrm{FTS}_{\mathrm{t}}$} & & $0.263 * * *$ \\
\hline & & $(0.000)$ \\
\hline \multirow[t]{2}{*}{ CTAt $_{t}$} & & $0.389 * *$ \\
\hline & & $(0.016)$ \\
\hline \multirow[t]{2}{*}{ DTAt $_{t}$} & & $0.357 * * *$ \\
\hline & & $(0.001)$ \\
\hline \multirow[t]{2}{*}{ LNTA $_{t}$} & & $0.201 * * *$ \\
\hline & & $(0.000)$ \\
\hline \multirow[t]{2}{*}{ ITAt } & & $0.320 * * *$ \\
\hline & & $(0.003)$ \\
\hline \multirow[t]{2}{*}{$\mathrm{R} \& \mathrm{DEXP}_{\mathrm{t}}$} & & $-0.410^{*}$ \\
\hline & & $(0.066)$ \\
\hline \multirow[t]{2}{*}{ ADVEXPt } & & -0.463 \\
\hline & & $(0.468)$ \\
\hline \multirow[t]{2}{*}{ Constant } & $-8.947 * * *$ & $-6.371 * * *$ \\
\hline & $(0.000)$ & $(0.000)$ \\
\hline Area under ROC Curve & 0.8132 & 0.8200 \\
\hline Year Fixed-Effect & Yes & Yes \\
\hline Industry Fixed-Effect & Yes & Yes \\
\hline Pseudo R-square & 0.2404 & 0.2516 \\
\hline $\mathrm{N}$ & 10,248 & 10,248 \\
\hline
\end{tabular}


Table 2.5 shows the result when the inverse Mills ratio, INVERSEMILLS, generated from the first-stage regression is included to estimate the parameters for

\section{Table 2. 5. Endogeneity - APTS and Income Shifting}

This table shows the results for the impact of auditor provided tax services on income shifting after correcting for endogeneity. The p-values are shown in brackets. Standard errors are clustered at the firm and year level. All continuous variables are mean centered. Appendix 1 provides definitions of the variables. *, **, ***, indicate statistical significance at the 10,5 , and 1 percent level, respectively.

\begin{tabular}{|c|c|}
\hline & Income Shifting \\
\hline \multicolumn{2}{|l|}{ Outbound Transfer } \\
\hline$\theta_{0}$ & $\begin{array}{l}0.096 * * * \\
(0.000)\end{array}$ \\
\hline$\theta_{1}$ & $\begin{array}{l}-0.003^{*} \\
(0.085)\end{array}$ \\
\hline$\theta$ inversemills & $\begin{array}{l}-0.123 * * * \\
(0.001)\end{array}$ \\
\hline \multicolumn{2}{|l|}{ Inbound Transfer } \\
\hline$\gamma_{0}$ & $\begin{array}{l}0.371 * * * \\
(0.000)\end{array}$ \\
\hline$\gamma_{1}$ & $\begin{array}{l}0.001 \\
(0.548)\end{array}$ \\
\hline$\gamma_{\text {inversemills }}$ & $\begin{array}{l}0.197 * * * \\
(0.000)\end{array}$ \\
\hline \multicolumn{2}{|l|}{ Return on Domestic Sales } \\
\hline$\rho_{\mathrm{d} 0}$ & $\begin{array}{l}0.123 * * * * \\
(0.000)\end{array}$ \\
\hline$\rho \mathrm{d} 1$ & $\begin{array}{l}-0.001 \\
(0.519)\end{array}$ \\
\hline $\rho$ dinversemills & $\begin{array}{l}-0.052 * * \\
(0.042)\end{array}$ \\
\hline \multicolumn{2}{|l|}{ Return on Foreign Sales } \\
\hline$\rho \mathrm{fo}$ & $\begin{array}{l}0.143 * * * \\
(0.000)\end{array}$ \\
\hline$\rho f 1$ & $\begin{array}{l}-0.001 \\
(0.365)\end{array}$ \\
\hline$\rho$ finversemills & $\begin{array}{l}0.050^{*} \\
(0.100)\end{array}$ \\
\hline Additional control on $\rho_{\mathrm{d}}$ and $\rho_{\mathrm{f}}$ & Yes \\
\hline Intercept ( $\triangle \mathrm{PIDOM}$ equation) & $\begin{array}{l}0.005 * * * \\
(0.000)\end{array}$ \\
\hline Intercept ( $\triangle \mathrm{PIFO}$ equation) & $\begin{array}{l}0.003 * * * \\
(0.000)\end{array}$ \\
\hline Rsquare $\Delta$ Pidom & 0.0612 \\
\hline Rsquare $\Delta$ Pifo & 0.1224 \\
\hline $\mathrm{N}$ & 10,248 \\
\hline
\end{tabular}

income shifting and return on sales in equations (2.6a) and (2.6b). The estimate of the incremental effect of APTS on outward shifting $\left(\theta_{1}\right)$ remains negative (- 
0.003 ), but is now significant at the $10 \%$ level. Although the coefficient on the inverse Mills ratio, INVERSEMILLS, is significant and negative, the results are qualitatively similar to the baseline result.

\subsubsection{Additional Tests}

To check the robustness of the findings, several additional tests are conducted. First, observations from the global financial crisis year, 2008 - 2009 are excluded, as the crisis may have influenced the decision on income shifting.

\section{Table 2. 6. Crisis Periods - APTS and Income Shifting}

This table shows the results for the impact of auditor provided tax services on income shifting. Column 1 shows the result when observations during the global financial crisis, $2008-2009$ are excluded. Column 2 shows the result when observations during the Dotcom crisis, 2002 and global financial crisis, 2008 - 2009 are excluded. The p-values are shown in brackets. Standard errors are clustered at the firm and year level. All continuous variables are mean centered. Appendix 1 provides definitions of the variables. *, **, and $* * *$, indicate statistical significance at the 10,5 , and 1 percent level, respectively.

\begin{tabular}{|c|c|c|}
\hline & \multicolumn{2}{|c|}{ Income Shifting } \\
\hline & Column 1 & Column 2 \\
\hline \multicolumn{3}{|l|}{ Outbound Transfer } \\
\hline \multirow[t]{2}{*}{$\theta_{0}$} & 0.030 & 0.028 \\
\hline & $(0.192)$ & $(0.217)$ \\
\hline \multirow[t]{2}{*}{$\theta_{1}$} & $-0.005 * *$ & $-0.006 * * *$ \\
\hline & $(0.031)$ & $(0.010)$ \\
\hline \multicolumn{3}{|l|}{ Inbound Transfer } \\
\hline \multirow[t]{2}{*}{$\gamma_{0}$} & $0.444 * * *$ & $0.448 * * *$ \\
\hline & $(0.000)$ & $(0.000)$ \\
\hline \multirow[t]{2}{*}{$\gamma_{1}$} & 0.002 & 0.001 \\
\hline & $(0.301)$ & $(0.395)$ \\
\hline \multicolumn{3}{|l|}{ Return on Domestic Sales } \\
\hline \multirow[t]{2}{*}{$\rho \mathrm{d} 0$} & $0.107 * * *$ & $0.115 * * *$ \\
\hline & $(0.000)$ & $(0.000)$ \\
\hline \multirow[t]{2}{*}{$\rho \mathrm{d} 1$} & $-0.001 * *$ & $-0.001 * * *$ \\
\hline & $(0.019)$ & $(0.001)$ \\
\hline \multicolumn{3}{|l|}{ Return on Foreign Sales } \\
\hline \multirow[t]{2}{*}{ 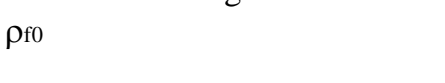 } & $0.157 * * *$ & $0.160 * * *$ \\
\hline & $(0.000)$ & $(0.000)$ \\
\hline \multirow[t]{2}{*}{$\rho f 1$} & -0.001 & -0.001 \\
\hline & $(0.165)$ & $(0.250)$ \\
\hline Additional control on $\rho d$ and $\rho f$ & Yes & Yes \\
\hline \multirow[t]{2}{*}{ Intercept ( $\triangle \mathrm{PIDOM}$ equation) } & $0.007 * * *$ & $0.007 * * *$ \\
\hline & $(0.000)$ & $(0.000)$ \\
\hline \multirow[t]{2}{*}{ Intercept ( $\Delta \mathrm{PIFO}$ equation) } & $0.005^{* * *}$ & $0.005^{* * *}$ \\
\hline & $(0.000)$ & $(0.000)$ \\
\hline Rsquare $\Delta$ Pidom & 0.0689 & 0.0778 \\
\hline Rsquare $\Delta$ Pifo & 0.1162 & 0.1223 \\
\hline $\mathrm{N}$ & 8,770 & 8,374 \\
\hline
\end{tabular}


The result is presented in Column 1 of Table 2.6. The result supports the baseline result, the parameter of outbound income shifting affected by APTS, $\theta_{1}$, remains negative (-0.005) and significant at 5\% level. Further, observations during the Dot.com crisis, 2002 and the global financial crisis, 2008 - 2009 are excluded. The results are reported in Column 2 of Table 2.6. It shows that $\theta_{1}$ parameter remains negative (-0.006) and significant at $1 \%$ level. Overall, Table 2.6 shows that the baseline result is not driven by the effect of the financial crisis periods.

An additional test to allow income shifting to vary with firm characteristics is conducted by expanding equations (2.5a) and (2.5b) to include the control variables. The results are presented in Table 2.7. Importantly, the incremental effect of APTS on outbound income shifting remains negative (-0.003) and significant at $10 \%$ level. This shows that the baseline result is robust to consideration of the firm-specific characteristics that may influence income shifting. The outbound income shifting is lower for higher worldwide return on sales, WWROS. In addition, worldwide return on sales, WWROS, is also positively related to return on foreign sales. This may imply that U.S. multinationals try to keep their money abroad when they have a higher worldwide return on sales. Outbound income shifting is also lower for higher R\&D expenses. This may signal that the tax treatment benefits of $R \& D$ expense can lower the motivation of U.S. multinationals to shift their income abroad. 
Table 2. 7. Firm Characteristics - APTS and Income Shifting

This table shows the results for the impact of auditor provided tax services on income shifting when control variables are included in the equations for both the income shifting and return on sales parameters. The p-values are shown in brackets. Standard errors are clustered at the firm and year level. All continuous variables are mean centered. Appendix 1 provides definitions of the variables. *,**, and $* * *$, indicate statistical significance at the 10,5 , and 1 percent level, respectively.

\begin{tabular}{|c|c|}
\hline & Income $\mathrm{S}$ \\
\hline \multicolumn{2}{|l|}{ Outbound Transfer } \\
\hline$\theta_{0}$ & $\begin{array}{l}0.165 * * * \\
(0.000)\end{array}$ \\
\hline ӨTAXFEes & $\begin{array}{l}-0.003^{*} \\
(0.066)\end{array}$ \\
\hline$\theta$ wwros & $\begin{array}{l}-0.914 * * * \\
(0.000)\end{array}$ \\
\hline$\theta$ R\&DEXP & $\begin{array}{l}-0.701 * * * * \\
(0.009)\end{array}$ \\
\hline$\theta_{\text {ADVEXP }}$ & $\begin{array}{l}0.152 \\
(0.823)\end{array}$ \\
\hline$\theta_{\text {FTS }}$ & $\begin{array}{l}0.274 * * * \\
(0.007)\end{array}$ \\
\hline$\theta_{\mathrm{CTA}}$ & $\begin{array}{l}0.112 \\
(0.522)\end{array}$ \\
\hline$\theta \mathrm{DTA}$ & $\begin{array}{l}0.092 \\
(0.511)\end{array}$ \\
\hline$\theta$ LnTA & $\begin{array}{l}0.046 * * * \\
(0.000)\end{array}$ \\
\hline$\theta$ өта & $\begin{array}{l}0.266^{*} \\
(0.079)\end{array}$ \\
\hline \multicolumn{2}{|l|}{ Inbound Transfer } \\
\hline$\gamma_{0}$ & $\begin{array}{l}0.272 * * * \\
(0.000)\end{array}$ \\
\hline$\gamma_{\text {TAXFEES }}$ & $\begin{array}{l}0.001 \\
(0.417)\end{array}$ \\
\hline$\gamma$ wwros & $\begin{array}{l}-0.501 * * \\
(0.034)\end{array}$ \\
\hline$\gamma_{R \& D E X P}$ & $\begin{array}{l}1.015^{* * *} \\
(0.000)\end{array}$ \\
\hline 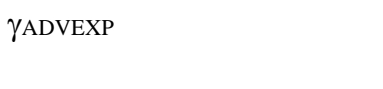 & $\begin{array}{l}0.807 \\
(0.124)\end{array}$ \\
\hline$\gamma$ FTS & $\begin{array}{l}0.358 * * \\
(0.012)\end{array}$ \\
\hline$\gamma_{\text {СТA }}$ & $\begin{array}{l}-0.171 \\
(0.397)\end{array}$ \\
\hline$\gamma$ DTA & $\begin{array}{l}-0.251 \\
(0.311)\end{array}$ \\
\hline$\gamma_{\text {LNTA }}$ & $\begin{array}{l}-0.025 \\
(0.124)\end{array}$ \\
\hline$\gamma$ IITA & $\begin{array}{l}-0.401 \\
(0.150)\end{array}$ \\
\hline $\begin{array}{l}\text { Return on Domestic Sales } \\
\rho_{\mathrm{d} 0}\end{array}$ & $\begin{array}{l}0.126 * * * \\
(0.000)\end{array}$ \\
\hline$\rho$ d TAXFEES & $\begin{array}{l}0.001 \\
(0.573)\end{array}$ \\
\hline$\rho \mathrm{d}$ Wwros & $\begin{array}{l}0.192 * * * \\
(0.000)\end{array}$ \\
\hline
\end{tabular}




\begin{tabular}{|c|c|}
\hline$\rho d$ R\&DEXP & $\begin{array}{l}0.396 * * * \\
(0.003)\end{array}$ \\
\hline$\rho d$ ADVEXP & $\begin{array}{l}0.220 \\
(0.357)\end{array}$ \\
\hline$\rho_{\mathrm{d} \text { FTS }}$ & $\begin{array}{l}0.059 * \\
(0.099)\end{array}$ \\
\hline ९d CTA & $\begin{array}{l}-0.022 \\
(0.740)\end{array}$ \\
\hline $\rho d$ DTA & $\begin{array}{l}0.013 \\
(0.760)\end{array}$ \\
\hline$\rho d$ LNTA & $\begin{array}{l}-0.003 \\
(0.427)\end{array}$ \\
\hline$\rho \mathrm{d}$ ITA & $\begin{array}{l}-0.110^{* * * *} \\
(0.001)\end{array}$ \\
\hline Return on Foreign Sales & \\
\hline$\rho \mathrm{f} 0$ & $\begin{array}{l}0.136 * * * \\
(0.000)\end{array}$ \\
\hline$\rho$ f TAXFEES & $\begin{array}{l}-0.001 \\
(0.224)\end{array}$ \\
\hline$\rho f$ wwros & $\begin{array}{l}0.234 * * * \\
(0.001)\end{array}$ \\
\hline$\rho f R \& D E X P$ & $\begin{array}{l}0.436 * * * \\
(0.001)\end{array}$ \\
\hline$\rho f$ ADVEXP & $\begin{array}{l}1.071 * * * \\
(0.000)\end{array}$ \\
\hline ff FTS & $\begin{array}{l}0.145^{* * *} \\
(0.000)\end{array}$ \\
\hline$\rho f$ CTA & $\begin{array}{l}0.022 \\
(0.765)\end{array}$ \\
\hline $\rho f$ DTA & $\begin{array}{l}-0.121 * * * \\
(0.004)\end{array}$ \\
\hline Pf LNTA & $\begin{array}{l}-0.005 \\
(0.257)\end{array}$ \\
\hline Pf ITA & $\begin{array}{l}-0.087 * \\
(0.055)\end{array}$ \\
\hline Intercept ( $\triangle \mathrm{PIDOM}$ equation) & $\begin{array}{l}0.004 * * * \\
(0.000)\end{array}$ \\
\hline Intercept ( $\Delta \mathrm{PIFO}$ equation) & $\begin{array}{l}0.004 * * * \\
(0.000)\end{array}$ \\
\hline Rsquare $\Delta$ Pidom & 0.0731 \\
\hline Rsquare $\Delta$ Pifo & 0.1249 \\
\hline $\mathrm{N}$ & 10,248 \\
\hline
\end{tabular}

\subsection{Conclusion}

U.S. multinationals are motivated to send their income abroad as a result of disadvantages of the U.S. tax system such as a high income tax rate and, until recently, being taxed on their worldwide income. Using the income shifting measurement model developed by Dyreng and Markle (2016), this study finds supporting evidence that APTS reduce outbound income shifting. This is 
consistent with the knowledge spillover view of APNAS rather than the impairment of independence view. This, therefore, supports hypothesis H1(a) that APTS have a negative association with income shifting behaviour of U.S. multinationals. The results provide evidence that supports continuing to allow auditors to provide tax services to their audit clients. The result holds after addressing potential endogeneity and is robust to excluding observations from the financial crisis periods. Furthermore, the result holds after including firm-specific characteristics as influences on the income shifting parameters. 


\section{CHAPTER THREE}

\section{AUDITOR PROVIDED TAX SERVICES AND DEFAULT RISK}

This chapter provides empirical evidence on the impact of APTS on default risk. This chapter begins with an introduction as in Section 3.1. Section 3.2 presents a review of the empirical literature on default risk and develops the hypotheses. Section 3.3 discusses the measures of default risk, the research design, and the sample selection criteria. Section 3.4 reports the descriptive statistics of the sample, results of the baseline regression, test for endogeneity, and results of the robustness test. Section 3.5 and 3.6 report the results on the influence of institutional ownership and information environment on the relationship between APTS and default risk, respectively. Section 3.7 presents the results on the channel through which APTS influence default risk. Finally, Section 3.8 concludes the chapter.

\subsection{Introduction}

In general, financial distress is a situation where a company's activities are influenced by the possibility of failure. Severe financial distress is likely to significantly disrupt the operation of the firm with management attention diverted away from normal business activities, higher cost of capital, and relationship with customers and suppliers may become stressed.

There are different states of financial distress leading to technical default, default, and bankruptcy. The early stages are characterized by poor performance and decline in cash flow. Continued negative outcomes may lead to technical default where the firm is unable to meet the terms (covenants) of its debt contracts (other than obligation to make interest and principal payment). Covenants may be 
able to be re-negotiated but failure to do and/or inability to make interest and principal payment will result in default, which, if ongoing, will lead to bankruptcy - a legal process which may involve liquidation. While there are these different states of financial distress, the term "default risk" is used on the capital market literature to indicate risk relating to financial distress. That is the sense default risk is used in this study.

Default risk is a matter of serious concern to investors and, generally, to government. There has thus been extensive research on cost of defaults (see, for example, Davydenko et al. (2012) and Glover (2016)) and on the factors likely to influence default risk (see, for example, Giesecke, Longstaff, Schaefer, and Strebulaev (2011), Hsu, Lee, Liu, and Zhang (2015), Bennett, Güntay, and Unal (2015), and Brogaard, Li, and Xia (2017)). However, none of the studies investigate the impact of APTS on default risk despite the extensive use of APTS (Klassen et al., 2016).

Audit has the potential to enhance the credibility of the financial information reported by the firm and is one of the elements of the firm's portfolio of governance mechanisms. As discussed in Chapter Two, the simultaneous provision of audit and APNAS has the potential to provide knowledge spillover effect and thus improves the work of the auditor. However, APNAS may instead impair the independence of the auditor and therefore lead to a decrease in the quality of the auditor. APNAS may thus improve or detract from the value of audit as a governance mechanism. Specifically, APTS may have a positive or negative impact on firm governance and hence may reduce or increase default risk. 
The competing hypotheses are tested using a sample of 21,364 firm-year observations on U.S. firms over the period 2003 - 2016. APTS are found to have a significant positive relationship with default risk, indicating that APTS impair auditor independence and audit quality, thereby increasing default risk. Heckman's two-stage procedure is used to address potential endogeneity and the result continues to hold. The result is robust to using alternative measure of default risk and to excluding the global financial crisis period. During the crisis period default risk would be anticipated to be higher and therefore maintenance of my baseline result indicates that it is not driven by the crisis period.

If the positive relationship between APTS and default risk reflects the impairment of auditor independence, other corporate governance mechanisms might mitigate the effect of APTS. To test this conjecture, institutional holdings are used as an external governance mechanism (see, for example, Hartzell and Starks (2003) and Chen, Harford, and Li (2007)). The positive relationship between APTS and default risk is expected to be lower for firms with stronger governance. As expected, the results confirm that the positive relationship between APTS and default risk is stronger for firms with lower institutional holdings.

Goyal and Wang (2013) argue that firms with favorable private information prefer short-term debt, while those with unfavorable private information prefer long-term debt. That is, short-term debt issuers will actually have lower default risk, while long-term debt issuers will actually have higher default risk. Liao, Chen, and $\mathrm{Lu}$ (2009) suggest that the information asymmetry between informed 
and uninformed traders results in deviations from a firm's correct credit risk assessment. Therefore, this study examines whether the strength of the relationship between the APTS and default risk depends on the degree of information asymmetry among investors in the firm. The results show that the higher the degree of information asymmetry, as reflected by lower analyst following, the higher the probability of informed trading, and the lower the stock liquidity, the stronger is the positive relationship between APTS and default risk. That is the positive relationship may just reflect high information asymmetry rather than APTS.

Finally, this study tests the channel through which APTS might increase default risk. If APTS impair auditor independence, earnings quality resulting from the audit process for firms with high APTS should be lower than for firms with low APTS. To provide evidence on this possible channel, this study examines the relationship between APTS and earnings quality. The results show that APTS are negatively related to earnings quality. This result provides evidence that APTS increase default risk through the impairment of auditor independence which then results in lower earnings quality.

This study makes a number of contributions. First, it adds to the prior literature on the factors influencing company default risk (see, for example, Giesecke et al. (2011), Hsu et al. (2015), Bennett et al. (2015), and Brogaard et al. (2017)). Second, it adds to the prior literature on the impact of APTS. Third, it finds that while there is a positive relationship between APTS and default risk, institutional ownership and the information environment can mitigate the relationship. The latter findings provide evidence on the importance of corporate 
governance to mitigate the effect of APTS. Finally, the study finds that earnings quality is the channel for the negative impact of APTS on default risk. The study thus provides further evidence on the continuing debate on the question of the SEC's policy of continuing to allow auditors to provide tax services. 5

\subsection{Literature Review and Hypotheses Development}

A review of the empirical literature on APNAS and, specifically, APTS was provided in Chapter Two and is not repeated here. Section 3.2.1 reviews the literature on default risk and Section 3.2.2 the determinants of default risk. Section 3.2.3 provides the hypotheses development for this study.

\subsubsection{Default Risk}

In general, default occurs when firms cannot meet their obligations. Merton (1974) argues that a firm's equity reflects the value of its assets where the strike price equals to the face value of companies' debt. In that case, default can happen when the value of equity drops below the face value of debt. As stated above, default (financial distress) disrupt the normal activities of a firm. Significant costs are likely to arise even if the default does not proceed to liquidation. Furthermore, business default, especially by large firms, may harm the economy through outcomes such as reduction of production and employment. Thus, regulators are also affected and understanding of default risk is thus an important issue for investors, regulators and the economy.

One stream of research on default investigates the costs resulting from default. Davydenko et al. (2012) infer the cost of default from the change in the

5 See Public Company Accounting Oversight Board, Auditor Independence Tax Services Roundtable. Available at: http://pcaobus.org/Rules/Rulemaking/Docket017/2004-0714_Roundtable_Transcript.pdf 
market value of firms' assets upon default. They argue that investors do not fully anticipate default in their decisions. Consequently, public announcement of default will contain information prompting investors to correct their valuations. The correction, therefore, reflects both the cost of default and the unanticipated news of default. Using data on a sample of 175 U.S. firms that defaulted during 1997 - 2010, the authors find that the mean (median) cost of default is $21.7 \%$ $(22.1 \%)$ of the market value of assets. Furthermore, they find that the cost of default for a distressed bond exchange is $14.7 \%$, while the cost of bankruptcy is $30.5 \%$. They also find that the cost of default for highly levered firms and investment grade firms is $20.2 \%$ and $28.8 \%$, respectively.

Glover (2016) argues that estimation of the cost of default using defaulted firms is subject to selection bias. Glover (2016) argues that firms with a higher cost of default tend to choose a lower level of leverage which mitigates default risk. Consequently, defaulted firms are those with a low cost of default. This selection bias thereby underestimates the cost of default that is incurred during the default period. The author proposes a structural model using the costs recognised by firms in setting their leverage and by credit makers in pricing debt. Using data on a sample of 2,505 U.S. firms over the period 1947 - 2010, the author finds that the mean (median) estimated cost of default is $45 \%$ (37\%) of firm value.

\subsubsection{The determinants of default risk}

Since the global financial crisis, there has been extensive research on the determinants of firm default risk (for example, Giesecke et al. (2011), Hsu et al. (2015), Bennett et al. (2015), and Brogaard et al. (2017)). Giesecke et al. (2011) examine U.S. bond default risk using data from 1866 - 2008. They find that 
default rates may be predicted using stock market returns, changes in stock market volatility, and changes in gross domestic product. Surprisingly, they fail to find predictive power for credit spreads. They also find that the bond market has experienced several clusters of default events. From those events, the worst occurred during the railroad crisis during the years $1873-1875$. They find that the default rate was more than one-third of the total par value of the corporate bond market during that period. Interestingly, they find that the worst three years of the great depression, 1933 - 1935, only ranks fourth with a total default rate of $12.88 \%$.

Hsu et al. (2015) investigate how innovation, as measured using patent records, is related to default risk and bond pricing. The authors argue that firms with more and higher quality patents have greater capacity to compete in the market. Hence, they are more likely to obtain first mover advantages and assume a market leader role. In addition, patents may increase the entry barriers for newcomers to the business. All these positive factors would improve firms' financial stability, thereby reducing default risk. Using data on 143 corporate bond issues by U.S. firms over the period 1976 - 2006, they find, as predicted, that firms having more and higher impact patents with high generality and originality scores, are less likely to default. In addition, they find that innovative firms have lower yields on their newly issued bonds in the primary market and lower excess bond returns in the secondary market.

Bennett et al. (2015) investigate the relationship between CEO inside debt holdings, default risk, and performance and find that CEO inside debt can serve as an important tool for forecasting bank holding company default. The authors 
argue that CEOs who maximize shareholders interest might engage in activities that are unfavorable for other stakeholders such as debt holders and deposit insurers. However, the interest of those other stakeholders might potentially be insured if CEOs are compensated using inside debt. This happens as CEOs are then bound to be more concerned about the firms' long-term solvency and thus engage in investments that are favorable for those other stakeholders. Hence, they believe that firms with higher inside debt compensation for their CEO are less likely to default and perform better during the financial crisis period that began in 2007. Using data on 371 U.S. bank holding companies in 2006Q4, they find that firms with higher CEO inside debt holdings relative to inside equity have lower default risk and better performance during the crisis period. In addition, they find that these bank holding companies gain better ratings on capital strength, earnings power, and risk management. This indicates that banks with higher CEO inside debt have a stronger capital position, better management, stronger earnings, and are in a better position to face market shocks.

Brogaard et al. (2017) examine the influence of stock liquidity on default risk. The authors argue that liquidity can lead to higher default risk if it increases noise trading, resulting in higher mispricing and stock volatility. However, liquidity may also reduce default risk if it enhances price efficiency or improves governance mechanisms of investors through ease of investors to exit. Using data on 7,128 U.S. firms during the period $1994-2014$, the authors find a negative association between liquidity and default risk and they estimate that a one standard deviation increase in liquidity is associated with a $26.89 \%$ decrease in default risk over the sample mean value of default risk. They find that improving 
stock price informational efficiency and corporate governance by blockholders are the channels by which liquidity reduces default risk. However, efficiency has the greater explanatory power.

\subsubsection{Hypotheses Development}

In general, investors rely on the financial information produced by firms. The degree and quality of information is, therefore, a key to investors in monitoring firms and make decisions based on that monitoring (see, for example, Berger and Hann (2003) and Armstrong, Guay, and Weber (2010)). An audit process is expected to provide reassurance that the financial information produced by management is of high quality. The independence of auditors is an important factor in the achievement of that objective. APTS may induce higher information quality if APTS do not impair auditor independence and result in knowledge spillover, thereby APTS may increase the ability of investors to monitor the firms. Consequently, APTS will be associated with a lower default probability. On the other hand, as APTS may lead to economic bonding between auditors and clients, the impairment of auditor independence can lower information quality disclosed in the audited financial statements. This will increase agency costs and reduce the ability of investors to monitor managers' behaviour. As a result, APTS will be associated with the increase of default risk.

Given those two contrasting views regarding the effect of APTS on default risk, this study tests the following hypotheses:

H1(a): The joint provision of audit and tax services by auditors has a negative association with default risk. 
H1(b): The joint provision of audit and tax services by auditors has a positive association with default risk.

A finding that APTS are associated with lower default risk will, on balance, support the knowledge spillover effect, while a finding that APTS are associated with higher default risk will support there being, on balance, a reduction in auditor independence.

\subsection{Measures of the key variables, Research Design, and Sample}

Section 3.3.1 discusses the measure of the default risk. Section 3.3.2 describes the baseline test model and Section 3.3.3 explains the construction of the sample.

\subsubsection{Measure of Default Risk}

The tests of the effect of APTS on default risk use the Altman Z-score as the measure of default risk. The Altman Z-score was developed to predict company bankruptcy. Eidleman (1995) argues that the initial Altman Z-score might underpredict certain types of bankruptcy. Altman thus made a correction to the initial form of the Z-score by eliminating the ratio of sales to total assets so as to better capture bankruptcy for non-manufacturing firms. For that reason, this study uses the modified Altman Z-score, DEFAULT1, as the primary measure of default risk (Altman, 1983). This study follows Edwards, Schwab, and Shevlin (2016) to calculate the Altman Z-score. The modified Altman Z-score is calculated as follows: 
DEFAULT1

$=6.56 x(($ Working Capital $) /($ Total Assets $))$

$+3.26 \times(($ Retained Earnings $) /($ Total Assets $))$

$+6.72 x(($ Earnings Before Income Taxes $) /($ Total Assets $))$

$+1.05 x(($ Market Value of Equity $)$

/ (Book Value of Debt)

Appendix 1 provides a restatement of the component inputs as Compustat data items.

The measure decreases with increasing default risk and, therefore, for ease of interpretation of the results, the outcome of the calculation of equation (3.1) is multiplied by -1 .

\subsubsection{Research Design}

The following cross-sectional regression model is used to test H1(a) and H1(b) regarding the relationship between APTS and default risk:

$\operatorname{DEFAULT1}_{j, t}=\alpha+\beta_{1} \operatorname{TAXFEES}_{j, t-1}+\beta_{2} \operatorname{CONTROLS}_{j, t-1}+\mathrm{e}_{j, t}$

where, TAXFEES is the measure of APTS, calculated as tax fees paid (in thousand) scaled by the square root of total assets as in Krishnan and Visvanathan (2011). As bigger firms are more likely to pay higher tax fees, deflating tax fees with total assets mitigates the possibility that the result generated from estimating equation (3.2) is just a reflection of the size effect. For example, bigger firms may have lower default risk compared to smaller firms. A finding of a significant negative (positive) value for $\beta_{1}$ would provide support for $\mathrm{H} 1(\mathrm{a})$ (H1(b)). Controls is a vector of control variables. 
Following Bharath and Shumway (2008), this study uses the following variables as control variables: LNEQUITY, the natural log of market value of equity at the end of the year as measured by share price at the end of year multiplied by total outstanding shares to control for the possibility that firms with high market value of equity are more capable of covering up obligations and thereby less likely to default; $L N D E B T$, the natural log of the face value of debt at the end of the year as measured by the sum of debt in current liabilities and onehalf of long term debt, to mitigate the possibility that firms with higher debt are more likely to default as they are more likely to fail to meet their obligations; INVVOL the inverse of the annualized stock return volatility to control for the effect of stock volatility on default risk; NI/TA indicates profitability as measured by the ratio of net income to total assets to mitigate the effect that more profitable firms are more likely to have lower default risk; and EXRET, the annual excess return as measured by the difference between company stock return and CRSP value-weighted return to control for the effect of firms' market performance.

In addition, this study follows Hsu et al. (2015) to include market-to-book value, $M T B$, to control for the effect of asset valuation on default risk; LOSS, to capture the effect of default caused by loss; and QUOTED, a measure of liquidity as Brogaard et al. (2017) find that liquidity is related to default risk. For the control variables, based on the extant literature and a priori reasoning, firms with higher LNEQUITY, INVVOL, NI/TA, MTB, and EXRET are expected to have lower default risk, while firms with higher $L N D E B T$ or experience loss, LOSS, are expected to have higher default risk. 
All continuous variables are winsorized at the $1_{\text {st }}$ and $99_{\text {th }}$ percentiles to account for outliers. The dependent variable is measured at year $t$ and the regressor variables at year $t$ - 1 . Using this specification mitigates the possibility of reverse causality relationship in which a defaulting firm may reduce their spending on tax consultant expense. Industry dummy variables based on the twodigit SIC code, as well as year dummy variables are used, to control for the impact of industry and year effects on default risk. Appendix 1 provides detailed definitions of the measures of all the variables used in the study

\subsubsection{Sample}

At first, this study identifies all the listed companies for the period 2003 2016 for which there was data available in the Compustat database to calculate the measure of default risk, DEFAULT1, and the control variables. This data was then merged with audit fees information available in the Audit Analytics database. The sample starts in year 2003 as APTS are measured in year t-1 and tax fees disclosures were limited prior to 2002. Data on analyst following and institutional ownership is obtained from I/B/E/S and Thomson Reuters databases, respectively. Data on all the other variables are sourced from the CRSP database.

Table 3. 1. Sample Selection - APTS and Default Risk

\begin{tabular}{lll}
\hline Criteria & Firms & Firm-Year \\
\hline $\begin{array}{l}\text { Firms with available information on audit fees during 2003 } \\
-2016 \text { period, with total assets at least \$1 million, and with } \\
\text { positive sales }\end{array}$ & & \\
$\begin{array}{l}\text { Less regulated firms (SIC 6000 - 6999) } \\
\text { Less firms with missing necessary data to calculate }\end{array}$ & 3,771 & 21,364 \\
$\begin{array}{l}\text { measures used to test the hypotheses and firms with zero } \\
\text { tax fees. }\end{array}$ & & \\
\hline
\end{tabular}


Observations with total assets less than $\$ 1$ million and observations with negative sales are excluded (Fernandes and Ferreira, 2009). Following Brogaard et al. (2017), observations on regulated financial firms (those with standard industrial classification (SIC) codes between 6000 - 6999) are excluded as these firms have different capital structure and are subject to various operating and reporting regulations. Observations with missing values are also deleted. Finally, to mitigate the possibility that firms have zero tax fees due to hiring tax specialists other than their auditors, observations with zero APTS fees are deleted. In other words, this study examines the influence of APTS on default risk conditional on firms purchasing tax services from their auditors. Application of these classification steps resulted in a final sample of 21,364 firm-year observations for the primary test. The sample selection process is shown in Table 3.1.

\subsection{Empirical results: Auditor Provided Tax Services and Default Risk}

This section presents the findings on the influence of APTS on default risk. Section 3.4.1 presents the descriptive statistics for the sample including the pairwise correlations among the test variables. The baseline results are reported in Section 3.4.2. Section 3.4.3 reports and discusses the results after addressing potential endogeneity. Section 3.4.4 presents the results from excluding the global financial crisis period. Section 3.4.5 shows the relationship between APTS and default risk by using alternative measures of default risk to mitigate the possibility of measurement bias.

\subsubsection{Descriptive Statistics}

Panel A, B, and C in Table 3.2 show the descriptive statistics for the sample. Panel A presents the descriptive statistics for the primary variables. Panel B 
presents the descriptive statistics for the control variables used in the main test.

Panel C presents the descriptive statistics for the other variables, used in the

endogeneity and robustness tests.

Table 3. 2. Descriptive Statistics - APTS and Default Risk

This table reports the descriptive statistics for the sample of 21,364 firm-year observations for the period 2003 - 2016. The Appendix 1 provides a detailed description of the variables.

\begin{tabular}{|c|c|c|c|c|c|c|c|c|}
\hline Variable & $\mathbf{N}$ & Mean & Median & STD & Min & P25 & P75 & Max \\
\hline \multicolumn{9}{|c|}{ Panel A : Dependent Variables } \\
\hline DEFAULT1 & 21,364 & -3.470 & -3.855 & 8.332 & -27.71 & -6.723 & -1.408 & 40.29 \\
\hline TAXFEES & 21,364 & 8.494 & 5.054 & 9.987 & 0.087 & 1.850 & 11.21 & 53.47 \\
\hline ATS & 21,364 & 0.504 & 1.000 & 0.500 & 0.000 & 0.000 & 1.000 & 1.000 \\
\hline DEFAULT2 & 21,364 & -2.725 & -2.776 & 3.932 & -15.45 & -4.317 & -1.420 & 16.11 \\
\hline EDF & 21,364 & 0.041 & 0.000 & 0.150 & 0.000 & 0.000 & 0.000 & 0.912 \\
\hline RAJGOPALSQ & 20,880 & 0.006 & 0.001 & 0.015 & 0.000 & 0.000 & 0.005 & 0.105 \\
\hline \multicolumn{9}{|c|}{ Panel B : Independent and main control variables } \\
\hline INSTOWN & 21,364 & 0.421 & 0.406 & 0.282 & 0.000 & 0.183 & 0.670 & 0.947 \\
\hline DEDOWN & 21,364 & 0.031 & 0.010 & 0.049 & 0.000 & 0.000 & 0.041 & 0.269 \\
\hline ANALYSTS & 21,364 & 5.266 & 3.500 & 5.608 & 0.000 & 0.750 & 7.917 & 25.17 \\
\hline PIN & 13,308 & 0.169 & 0.140 & 0.100 & 0.022 & 0.097 & 0.219 & 0.500 \\
\hline EQUITY & 21,364 & 5,277 & 801.3 & 14,780 & 6.196 & 172.4 & 3,111 & 106,292 \\
\hline DEBT & 21,364 & 760.4 & 107.8 & 1,880 & 0.000 & 11.89 & 518.0 & 12,284 \\
\hline NI/TA & 21,364 & -0.018 & 0.035 & 0.204 & -1.156 & -0.017 & 0.072 & 0.237 \\
\hline$\sigma E(V O L A T I L I T Y)$ & 21,364 & 0.434 & 0.362 & 0.273 & 0.103 & 0.247 & 0.540 & 1.609 \\
\hline EXRET & 21,364 & 0.056 & -0.015 & 0.495 & -0.783 & -0.222 & 0.221 & 2.425 \\
\hline МТB & 21,364 & 1.852 & 1.480 & 1.173 & 0.642 & 1.154 & 2.092 & 7.637 \\
\hline QUOTED & 21,364 & 0.007 & 0.002 & 0.013 & 0.000 & 0.001 & 0.007 & 0.076 \\
\hline AMIHUD & 21,364 & 0.094 & 0.000 & 0.413 & 0.000 & 0.000 & 0.006 & 3.230 \\
\hline ZERO & 21,364 & 0.028 & 0.016 & 0.033 & 0.000 & 0.008 & 0.036 & 0.163 \\
\hline LOSS & 21,364 & 0.295 & 0.000 & 0.456 & 0.000 & 0.000 & 1.000 & 1.000 \\
\hline \multicolumn{9}{|c|}{ Panel C: Other Control Variables } \\
\hline MERGER & 21,364 & 0.436 & 0.000 & 0.496 & 0.000 & 0.000 & 1.000 & 1.000 \\
\hline NOL & 21,364 & 0.541 & 1.000 & 0.498 & 0.000 & 0.000 & 1.000 & 1.000 \\
\hline CAPINT & 21,364 & 0.303 & 0.216 & 0.263 & 0.011 & 0.103 & 0.433 & 1.192 \\
\hline AUDINDEP & 21,364 & 0.135 & 0.057 & 0.220 & 0.000 & 0.009 & 0.153 & 1.334 \\
\hline AUDTENURE & 21,364 & 10.97 & 8.000 & 8.998 & 1.000 & 4.000 & 15.00 & 39.00 \\
\hline LEVERAGE & 21,364 & 0.551 & 0.227 & 1.035 & 0.000 & 0.078 & 0.553 & 7.176 \\
\hline AUDFEES & 21,364 & 13.94 & 14.00 & 1.285 & 11.04 & 13.06 & 14.83 & 16.95 \\
\hline AUDCHANGE & 21,364 & 0.062 & 0.000 & 0.241 & 0.000 & 0.000 & 0.000 & 1.000 \\
\hline LNTA & 21,364 & 6.714 & 6.777 & 2.048 & 2.199 & 5.298 & 8.128 & 11.39 \\
\hline TA & 21,364 & 4,969 & 877.4 & 12,501 & 9.017 & 200.0 & 3,386 & 88,182 \\
\hline GROWTH & 21,364 & 0.106 & 0.047 & 0.323 & -0.480 & -0.035 & 0.151 & 1.804 \\
\hline
\end{tabular}


The mean (median) value of DEFAULT1 is $-3.470(-3.855)$; the mean (median) value of EQUITY is 5,277 (801.3); the mean (median) value of DEBT is 760.4 (107.8); the mean (median) value of EXRET is $5.6 \%(-1.5 \%)$; the mean (median) of $\sigma E$ is $0.434(0.362)$; the mean (median) value of the natural logarithm of audit fees, AUDFEES, is 13.94 (14.00); the mean (median) value of profitability, $N I / T A$, is $-1.8 \%(3.5 \%)$; the mean (median) value of leverage, LEVERAGE, is $55.1 \%(22.7 \%)$; the mean (median) value of assets growth, GROWTH, is $10.6 \%(4.7 \%)$; and the mean (median) value of total assets, $T A$, is 4,969 (877.4). Appendix 3 provides the Pearson correlation matrix for all of the variables used in the study. The pairwise correlations are broadly consistent with expectations but individual values are of limited significance as the association of APTS with default risk is tested in a multivariate context. Importantly, the correlations are not indicative of multicollinearity being a problem for estimation of the test model.

\subsubsection{Baseline Results}

Equation (3.2) is estimated using the full sample and the baseline regression results are reported in Table 3.3. Column 1 shows the result of including only the control variables as in Bharath and Shumway (2008) and Brogaard et al. (2017) and a similar result is found. The results show that default risk as measured by DEFAULT1 decreases with higher LNEQUITY, INVVOL, NI/TA, and EXRET. As expected, default risk increases with higher value of $L N D E B T$. For those variables, the significance levels are at $1 \%$ except for INVVOL and EXRET which are significant at $5 \%$ and $10 \%$, respectively. 
Column 2 shows the result when the additional control variable, QUOTED is included, which increases with illiquidity. The result is similar to that in Brogaard et al. (2017). Specifically, $L N D E B T$ and $Q U O T E D$ are significantly and positively related to DEFAULT1 which mean that default risk increase with increased debt and illiquidity. Both of those variables are significant at $1 \%$ level. Default risk as measured by DEFAULT1 decreases with higher LNEQUITY, INVVOL, and NI/TA at $1 \%$ significance level. The coefficient on EXRET is negative and significant at $5 \%$ level which indicates that higher excess return results in lower default risk.

Column 3 shows the result when the test variable, TAXFEES is included in the estimation of equation (3.2). The result shows that TAXFEES is positively related to DEFAULT1. This indicates that firms with higher APTS have higher default risk. For the control variables, default risk decreases with higher LNEQUITY, INVVOL, EXRET, and NI/TA. As expected, default risk is higher for firms with higher LNDEBT and QUOTED.

Column 4 of Table 3.3 shows the fully specified model with all the control variables included in the estimation model. TAXFEES is positively related to DEFAULT1. For control variables, as expected, the coefficients of LNEQUITY, NI/TA, MTB, and INVVOL are negative and significantly related to DEFAULTI which indicates that firms with higher equity, higher profitability, higher marketto-book-ratio, and higher inverse stock return volatility have lower default risk. The estimated coefficients on $L N D E B T$ and $Q U O T E D$ are significantly positive which show that firms with higher debt and illiquidity have higher default probability. However, there is no significant effect for EXRET and LOSS. Overall, these results for the control variables are similar to the results found in prior 
research on default risk (see, for example, Bharath and Shumway (2008) and Brogaard et al. (2017)).

Table 3. 3. Baseline Result - APTS and Default Risk

This table shows the regression result on the impact of auditor provided tax services on default risk. Column 1 shows the result when only the control variables are included, as in Bharath and Shumway (2008) and Brogaard et al. (2017). Column 2 presents the result when the liquidity measure, QUOTED, is included in the regression equation. Column 3 shows the result when TAXFEES is included in the regression equation. Column 4 shows the result when TAXFEES and all the control variables are included in the regression equation. Continuous variables are winsorized at the 1 and 99 percent levels. The pvalues are shown in brackets. Standard errors are clustered at the firm and year level. Appendix 1 provides definitions of all the variables. *,**, and $*^{* *}$, indicate statistical significance at the 10,5 , and 1 percent level, respectively.

\begin{tabular}{|c|c|c|c|c|}
\hline & & $D E F A$ & & \\
\hline & Column 1 & Column 2 & Column 3 & Column 4 \\
\hline$T_{A X F E E S_{t-1}}$ & & & $0.029 * * *$ & $0.028 * * *$ \\
\hline LNEOUITY $_{t-1}$ & $-1.669 * * *$ & $-1.454 * * *$ & $-1.474 * * *$ & $-1.205 * * *$ \\
\hline & $(0.000)$ & $(0.000)$ & $(0.000)$ & $(0.000)$ \\
\hline$L_{N D E B T_{t-1}}$ & $1.433 * * *$ & $1.398 * * *$ & $1.391 * * *$ & $1.211 * * *$ \\
\hline & $(0.000)$ & $(0.000)$ & $(0.000)$ & $(0.000)$ \\
\hline$I_{N V O O L_{t-1}}$ & $-0.094 * *$ & $-0.134 * * *$ & $-0.132 * * *$ & $-0.176 * * *$ \\
\hline & $(0.014)$ & $(0.001)$ & $(0.001)$ & $(0.000)$ \\
\hline$N I / T A_{t-1}$ & $-20.65 * * *$ & $-20.47 * * *$ & $-20.46 * * *$ & $-22.08 * * *$ \\
\hline & $(0.000)$ & $(0.000)$ & $(0.000)$ & $(0.000)$ \\
\hline$E_{X X E T_{t-1}}$ & $-0.288^{*}$ & $-0.388 * *$ & $-0.372 * *$ & -0.088 \\
\hline & $(0.095)$ & $(0.015)$ & $(0.020)$ & $(0.383)$ \\
\hline QUOTED $t-1$ & & $45.02 * * *$ & $44.60 * * *$ & $48.45 * * *$ \\
\hline & & $(0.000)$ & $(0.000)$ & $(0.000)$ \\
\hline$M T B_{t-1}$ & & & & $\begin{array}{l}-0.656^{* * * *} \\
(0.000)\end{array}$ \\
\hline $\operatorname{LOSS}_{t-1}$ & & & & -0.442 \\
\hline & & & & $(0.118)$ \\
\hline Constant & $-4.650 * *$ & $-6.509 * * *$ & $-6.747 * * *$ & $-6.438 * * *$ \\
\hline & $(0.038)$ & $(0.004)$ & $(0.003)$ & $(0.004)$ \\
\hline Year Fixed-Effect & Yes & Yes & Yes & Yes \\
\hline Industry Fixed-Effect & Yes & Yes & Yes & Yes \\
\hline $\mathrm{R}$-square & 0.4300 & 0.4324 & 0.4334 & 0.4386 \\
\hline Adj. R-square & 0.4280 & 0.4303 & 0.4314 & 0.4365 \\
\hline $\mathrm{N}$ & 21,364 & 21,364 & 21,364 & 21,364 \\
\hline
\end{tabular}

The results reported in Table 3.3 provide support for H1(b) that APTS induce higher default risk. This supports the argument that APTS impair auditor 
independence, thereby leading to lower audit quality and higher default probability.

\subsubsection{Potential Endogeneity}

Previous studies find that a firm' decision to purchase tax services from their incumbent auditors is an intentional decision and driven by several factors (see, for example, Omer et al. (2006), Lassila et al. (2010), McGuire et al. (2012), Krishnan and Visvanathan (2011), Krishnan et al. (2013), and Gleason et al. (2018)). This study addresses that potential endogeneity problem by estimating a two-stage model (Heckman, 1979). First, the following probit regression model is estimated:

$$
\begin{aligned}
& \operatorname{Prob}\left(\text { ATS }_{j, t-1}\right) \\
& =\alpha+\beta_{1} M E R G E R_{j, t-1}+\beta_{2} N O L_{j, t-1} \\
& +\beta_{3} \text { CAPINT }_{j, t-1}+\beta_{4} \text { INSTOWN }_{j, t-1} \\
& +\beta_{5} A U D I N D E P_{j, t-1}+\beta_{6} A U D T E N U R E_{j, t-1} \\
& +\beta_{7} L E V E R A G E_{j, t-1}+\beta_{8} A U D F E E S_{j, t-1} \\
& +\beta_{9} A U D C H A N G E_{j, t-1}+\beta_{10} L N E Q U I T Y_{j, t-1} \\
& +\beta_{11} L N D E B T_{j, t-1}+\beta_{12} I N V V O L_{j, t-1} \\
& +\beta_{13} \frac{N I}{T A}{ }_{j, t-1}+\beta_{14} \text { EXRET }_{j, t-1}+\beta_{15} \text { MTB }_{j, t-1}+\beta_{16} \text { QUOTED }_{j, t-1} \\
& +\beta_{17} \text { LOSS }_{j, t-1}+\beta_{18} \text { INDUSTRYDUMMY }+\beta_{19} \text { YEARDUMMY } \\
& +\mathrm{e}_{j, t-1}
\end{aligned}
$$

Similar to Gleason et al. (2018), ATS is an indicator variable equal to one if firm's auditor tax fee is above the yearly median of sample firms and 0 otherwise. Following previous studies McGuire et al. (2012) and Gleason et al. (2018) several exclusionary variables are included: $M E R G E R$, an indicator variable coded one if there is a merger activity; NOL, a dummy variable coded one if there is a tax loss carry forward; CAPINT, the ratio of net property, plant, and equipment on total assets in previous year; INSTOWN, the average of institutional 
ownership during the year; AUDINDEP, the ratio of non-audit fees on audit fees; AUDTENURE, number of years the auditor has served the companies; LEVERAGE, sum of the book value of short-term and long-term debt deflated by the book value of equity; AUDFEES, natural logarithm of audit fees; AUDCHANGE, a dummy variable equal to one if the firm change the auditor from the prior year. The control variables included in equation (3.2) are also included. The resulting inverse Mills ratio, INVERSEMILLS, is then included as an additional variable in estimation of equation (3.2). This study uses the average of institutional ownership instead of the percentage of institutional ownership at the beginning year as in Gleason et al. (2018), because of the possibility that the decision to purchase tax services from the incumbent auditor can occur during the year. Appendix 1 provides detailed definitions for the measures of all the variables used in the study.

The results from estimating equation (3.3) are reported in Table 3.4. Column 1 shows the result when only exclusionary variables are included. The results show that the decision to purchase tax services from auditors, ATS, is positively related to MERGER, INSTOWN, AUDINDEP, AUDFEES, and AUDTENURE, while it is negatively related to, LEVERAGE, and AUDCHANGE. Column 2 shows the result of estimating equation (3.3) by including all exclusionary variables and the control variables included in estimation of equation (3.2). The probability of purchasing tax services from auditors, ATS, is positively related to AUDINDEP, AUDTENURE, LEVERAGE, AUDFEES, LNEQUITY, and NI/TA. It is negatively related to CAPINT, AUDCHANGE, MTB, QUOTED, and LOSS. In general, the findings for the explanatory variables are similar to those reported in 
Table 3. 4. First-Stage Model - APTS and Default Risk

This table shows the regression result of the first stage regression (equation 3.3). Continuous variables are winsorized at the 1 and 99 percent levels. The p-values are shown in brackets. Appendix 1 provides definitions of variables. *, **, and ***, indicate statistical significance at the 10,5 , and 1 percent level, respectively.

\begin{tabular}{|c|c|c|}
\hline & \multicolumn{2}{|c|}{$A T S$} \\
\hline & Column 1 & Column 2 \\
\hline \multirow[t]{2}{*}{ MERGERRt-1 } & $0.059 * * *$ & 0.008 \\
\hline & $(0.006)$ & $(0.704)$ \\
\hline \multirow{2}{*}{$N O L_{t-1}$} & -0.010 & 0.033 \\
\hline & $(0.653)$ & $(0.127)$ \\
\hline \multirow[t]{2}{*}{ CAPINT $_{t-1}$} & -0.043 & $-0.235 * * *$ \\
\hline & $(0.440)$ & $(0.000)$ \\
\hline \multirow[t]{2}{*}{$I_{N S T O W N}-1$} & $0.327 * * *$ & 0.056 \\
\hline & $(0.000)$ & $(0.289)$ \\
\hline \multirow[t]{2}{*}{$A U D I N D E P_{t-1}$} & $0.485^{* * *}$ & $0.374 * * *$ \\
\hline & $(0.000)$ & $(0.000)$ \\
\hline \multirow[t]{2}{*}{ AUDTENURE $E_{t-1}$} & $0.009 * * *$ & $0.007 * * *$ \\
\hline & $(0.000)$ & $(0.000)$ \\
\hline \multirow[t]{2}{*}{ LEVERAGE $E_{t-1}$} & $-0.018^{*}$ & $0.053 * * *$ \\
\hline & $(0.065)$ & $(0.000)$ \\
\hline \multirow[t]{2}{*}{ AUDFEES $S_{t-1}$} & $0.721 * * *$ & $0.547 * * *$ \\
\hline & $(0.000)$ & $(0.000)$ \\
\hline \multirow[t]{2}{*}{$A U D C H A N G E_{t-1}$} & $-0.094 * *$ & $-0.097 * *$ \\
\hline & $(0.034)$ & $(0.031)$ \\
\hline \multirow[t]{2}{*}{ LNEQUITY $_{t-1}$} & & $0.098 * * *$ \\
\hline & & $(0.000)$ \\
\hline \multirow[t]{2}{*}{$L N D E B T_{t-1}$} & & 0.006 \\
\hline & & $(0.520)$ \\
\hline \multirow[t]{2}{*}{$I N V V O L_{t-1}$} & & -0.006 \\
\hline & & $(0.436)$ \\
\hline \multirow[t]{2}{*}{$N I / T A_{t-1}$} & & $0.380 * * *$ \\
\hline & & $(0.000)$ \\
\hline \multirow[t]{2}{*}{$\operatorname{EXRET}_{t-1}$} & & -0.021 \\
\hline & & $(0.363)$ \\
\hline \multirow[t]{2}{*}{$M_{T B} B_{t-1}$} & & $-0.067 * * *$ \\
\hline & & $(0.000)$ \\
\hline \multirow[t]{2}{*}{ QUOTED ${ }_{t-1}$} & & $-9.944 * * *$ \\
\hline & & $(0.000)$ \\
\hline \multirow[t]{2}{*}{$\operatorname{LOSS}_{t-1}$} & & $-0.071 * *$ \\
\hline & & $(0.021)$ \\
\hline \multirow[t]{2}{*}{ Constant } & $-9.129 * * *$ & $-7.036 * * *$ \\
\hline & $(0.000)$ & $(0.000)$ \\
\hline Area under ROC Curve & 0.8251 & 0.8301 \\
\hline Year Fixed-Effect & Yes & Yes \\
\hline Industry Fixed-Effect & Yes & Yes \\
\hline Pseudo R-square & 0.2668 & 0.2768 \\
\hline $\mathrm{N}$ & 21,364 & 21,364 \\
\hline
\end{tabular}


previous studies (see, for example, McGuire et al. (2012) and Gleason et al. (2018)). The selection score for the full model is 0.8301 which suggest that the selection model has excellent discriminatory power.

This study then generates the inverse Mills ratio, INVERSEMILLS, from the result presented in Column 2 of Table 3.4 to re-estimate equation (3.2). The result is reported in Table 3.5. The results are qualitatively similar to the baseline result.

\section{Table 3. 5. Endogeneity - APTS and Default Risk}

This table shows the regression result on the impact of auditor provided tax services on default risk after addressing endogeneity issue. Continuous variables are winsorized at the 1 and 99 percent levels. The p-values are shown in brackets. Standard errors are clustered at the firm and year level. Appendix 1 provides definitions of variables. *, **, and ***, indicate statistical significance at the 10,5, and 1 percent level, respectively.

\begin{tabular}{ll}
\hline & DEFAULT1 \\
\hline TAXFEES $_{t-1}$ & $0.024^{* * *}$ \\
& $(0.000)$ \\
LNEQUITY $_{t-1}$ & $-1.396^{* * *}$ \\
& $(0.000)$ \\
LNDEBT $_{t-1}$ & $1.148^{* * *}$ \\
& $(0.000)$ \\
INVVOL $_{t-1}$ & $-0.151^{* * *}$ \\
& $(0.000)$ \\
NI/TA $t-1$ & $-22.35^{* * *}$ \\
& $(0.000)$ \\
EXRET $_{t-1}$ & -0.054 \\
& $(0.566)$ \\
QUOTED $_{t-1}$ & $61.59^{* * *}$ \\
& $(0.000)$ \\
MTB $_{t-1}$ & $-0.541^{* * *}$ \\
& $(0.000)$ \\
LOSS $_{t-1}$ & $-0.489^{*}$ \\
& $(0.079)$ \\
IINVERSEMILLS $_{t-1}$ & $-1.079^{* * *}$ \\
& $(0.007)$ \\
Constant & $-4.722^{* *}$ \\
& $(0.044)$ \\
Year Fixed-Effect & Yes \\
Industry Fixed-Effect & Yes \\
R-square $_{\text {Adj. R-square }}$ & 0.4394 \\
N & 0.4373 \\
& 21,364 \\
&
\end{tabular}

In particular, the relationship between TAXFEES and DEFAULT1 remains positive which is consistent with APTS impairing auditor independence thereby 
lowering the audit quality and increasing default probability. The coefficients on the control variables show that default risk is higher for firms with a higher face value of debt (LNDEBT) and higher stock illiquidity (QUOTED), but decreases with higher market capitalization (LNEQUITY), higher market-to-book ratio $(M T B)$, higher annualized inverse stock return volatility (INVVOL), and higher profitability (NI/TA). The result that firms experiencing loss in year $\mathrm{t}-1$ appear to have lower default risk in year $t$ is difficult to explain.

\subsubsection{Robustness Checks: Global Financial Crisis}

Given that the sample period includes the global financial crisis during which there would have been a higher risk of default, this study tests for the possible effect of this on the relationship between APTS and default risk by re-estimating the test model, equation (3.2), and excluding observations from the crisis period, 2008-2009. The results are reported in Table 3.6. The relationship between TAXFEES and DEFAULT1 is positive and significant at $1 \%$ level. This result provides evidence which indicates that the positive impact of APTS on default risk is not driven by the inclusion of observations from the global financial crisis. 
Table 3. 6. Global Financial Crisis - APTS and Default Risk

This table shows the regression result on the influence of auditor provided tax services on default risk when observations from the crisis period, 2008 -2009 are excluded. Continuous variables are winsorized at the 1 and 99 percent levels. Appendix 1 provides definitions of all variables. Standard errors are clustered at firm and year level. The pvalues are shown in brackets. ${ }^{*}, * *$, and $* * *$, indicate statistical significance at the 10,5 , and 1 percent level, respectively.

\begin{tabular}{ll}
\hline & DEFAULT1 \\
\hline TAXFEES $_{t-1}$ & $0.028^{* * *}$ \\
& $(0.000)$ \\
LNEQUITY $_{t-1}$ & $-1.258^{* * *}$ \\
& $(0.000)$ \\
LNDEBT $_{t-1}$ & $1.267 * *$ \\
& $(0.000)$ \\
INVVOL $_{t-1}$ & $-0.154^{* * *}$ \\
& $(0.000)$ \\
NI/TA & $t-1$ \\
& $-22.33^{* * *}$ \\
EXRET $_{t-1}$ & $(0.000)$ \\
& -0.081 \\
QUOTED $_{t-1}$ & $(0.478)$ \\
& $45.59^{* * *}$ \\
MTB $_{t-1}$ & $(0.000)$ \\
& $-0.726^{* * *}$ \\
LOSS $_{t-1}$ & $(0.000)$ \\
& $-0.498^{*}$ \\
Constant & $(0.083)$ \\
& $-5.840^{* * *}$ \\
Year Fixed-Effect & $(0.004)$ \\
Industry Fixed-Effect $_{\text {R-square }}$ & Yes \\
Adj. R-square & Yes \\
N & 0.4361 \\
\hline
\end{tabular}

\subsubsection{Robustness Checks: Alternative Measures of Default Risk}

To test the robustness of the results reported above to choice of measure for default risk, equation (3.2) is re-estimated using two other measures of default risk. First, this study uses the initial Altman Z-score, DEFAULT2, (Altman, 1968) calculated as follows (and, as with DEFAULT1, this study multiplies the outcome of the calculation of equation (3.4) by -1): 


$$
\begin{aligned}
\text { DEFAULT2 }= & 1.2 x((\text { Working Capital }) /(\text { Total Assets })) \\
& +1.4 x((\text { Retained Earnings }) /(\text { Total Assets })) \\
& +3.3 x((\text { Earnings Before Income Taxes }) /(\text { Total Assets })) \\
& +0.6 x(\text { Market Value of Equity } / \text { Book Value of Debt })) \\
& +1 x((\text { Sales }) /(\text { Total Assets }))
\end{aligned}
$$

In Appendix 1, this study restates the component inputs as Compustat data items.

Second, this study measures default risk by the expected default frequency, $E D F$, developed in Bharath and Shumway (2008) which is a simplified version of the Merton (1974) distance-to-default measure. The distance-to-default measure is based on the Merton (1974) view of equity as a call option on the value of the firm with a strike price equal to the face value of the debt and thus default occurs when the value of the assets falls below the face value of the debt. The distanceto-default measure is widely used (Basel Committee on Banking Supervision, 1999 and Vassalou and Xing, 2004). The EDF measure retains the Merton models' structural form and some basic inputs but simplifies the calculation. Bharath and Shumway (2008) show that it performs better than the distance-todefault measure in out-of-sample forecasts of default.

Following Bharath and Shumway (2008) and Brogaard et al. (2017), EDF is calculated as follows;

$$
\begin{gathered}
D D_{j, t}=\frac{\log \left(\frac{\text { Equity }_{j, t}+\text { Debt }_{j, t}}{\text { Debt }_{j, t}}\right)+\left(r_{j, t-1}-\frac{\sigma_{v j, t}^{2}}{2}\right) \times T_{j, t}}{\sigma_{V j, t} \times \sqrt{T_{j, t}}} \\
\sigma_{V j, t}=\frac{\text { Equity }_{j, t}}{\text { Equity }_{j, t}+\text { Debt }_{j, t}} \times \sigma_{E j, t}+\frac{\text { Debt }_{j, t}}{\text { Equity }_{j, t}+\text { Debt }_{j, t}} \times(0.05 \\
\left.+0.25 \times \sigma_{E j, t}\right)
\end{gathered}
$$




$$
E D F_{j, t}=N\left(-D D_{j, t}\right)
$$

where. Equity E $_{j, t}$ refers to the number of shares outstanding multiplied by the stock price of firm $j$ at the end of year $t ;$ Debtj,t $_{j}$ is the sum of current liabilities and one-half of long-term debt of firm $j$ at the end of year $t ; r_{j, t-1}$ is firm $j$ 's past annual return, calculated from monthly stock returns over year $t-1 ; \sigma E j, t$ refers to the stock return volatility of firm $j$ during year $t$, estimated using the monthly stock return from year $t-1$ and $\sigma_{v j, t}$ is an approximation to the firm's assets volatility in year $t$; $T_{j, t}$ refers to the time frame, which is set to one year; and $N($.$) is the cumulative$ standard normal distribution function. 6

Table 3.7 shows the results of re-estimation of the test model using DEFAULT2 and EDF as alternative measure of default risk. Consistent with the baseline result, TAXFEES is positively related to DEFAULT2, and significant at $1 \%$ which indicates that firms with higher APTS have higher default risk. Furthermore, the relationship between TAXFEES and EDF is positive and significant at the 5\% level. Similarly, this indicates that higher APTS lead to a higher default risk. Thus, using alternative measures of default risk, the result remains that APTS lead to higher default risk.

6 Since the tax fee is annual data, this study uses annual data to calculate Debtj,t. 
Table 3. 7. Alternative Measures of Default Risk - APTS and Default Risk

This table presents the regression results on the influence of auditor provided tax services on default risk using two alternative measures of default risk. Specifically, Column 1 shows the results using the initial Altman Z-score (DEFAULT2) as the measure of default risk and Column 2 shows the result when using the expected default frequency, $E D F$, as the measure of default risk. Continuous variables are winsorized at the 1 and 99 percent levels. Standard errors are clustered at the firm and year level. Appendix 1 provides definitions of all variables. The p-values are shown in brackets. *,**, and ***, indicate statistical significance at the 10,5 , and 1 percent level, respectively.

\begin{tabular}{lll}
\hline & DEFAULT2 & EDF \\
\hline TAXFEES $_{t-1}$ & $0.009^{* * *}$ & $0.001^{* *}$ \\
& $(0.005)$ & $(0.024)$ \\
LNEQUITY $_{t-1}$ & $-0.530^{* * *}$ & $-0.036^{* * *}$ \\
& $(0.000)$ & $(0.000)$ \\
LNDEBT $_{t-1}$ & $0.590^{* * *}$ & $0.032^{* * *}$ \\
& $(0.000)$ & $(0.000)$ \\
INVVOL $_{t-1}$ & $-0.084^{* * *}$ & $-0.012^{* * *}$ \\
& $(0.000)$ & $(0.000)$ \\
NI/TA $t-1$ & $-10.21^{* * *}$ & 0.008 \\
& $(0.000)$ & $(0.604)$ \\
EXRET $_{t-1}$ & -0.024 & $-0.068^{* * *}$ \\
& $(0.616)$ & $(0.000)$ \\
QUOTED $t-1$ & $12.07 * * *$ & 0.453 \\
& $(0.007)$ & $(0.107)$ \\
MTB $t-1$ & $-0.488^{* * *}$ & $0.015^{* * *}$ \\
& $(0.000)$ & $(0.000)$ \\
LOSS $t-1$ & -0.127 & $0.037^{* * *}$ \\
& $(0.287)$ & $(0.000)$ \\
Constant & $-3.774^{* * *}$ & $0.114 * * *$ \\
& $(0.002)$ & $(0.000)$ \\
Industry Fixed-Effect & Yes & Yes \\
Year Fixed-Effect & Yes & Yes \\
R-square & 0.4423 & 0.3082 \\
Adj. R-square & 0.4402 & 0.3056 \\
N & 21,364 & 21,364 \\
\hline
\end{tabular}

\subsection{Institutional Ownership, Auditor Provided Tax Services, and Default}

\section{Risk}

Brogaard et al. (2017) argue that good corporate governance induces managers to invest in value-enhancing activities and mitigates the tendency to opportunistic behaviour by managers, thereby it may lead to lower default risk. If the positive relationship between APTS and default risk is due to the impairment of auditor independence, better corporate governance may mitigate the negative 
outcome of APTS. To test this conjecture, this study tests the impact of APTS on default risk including the influence of institutional ownership. This study focuses on institutional investors given their important role as external monitors of firms (Hartzell and Starks, 2003). In addition, this study also considers dedicated institutions since they are long term shareholders who play a special monitoring role (Chen et al., 2007).

Test of the impact of institutional ownership on the relationship between APTS and default risk uses two measures of institutional ownership that are well established in the governance literature, viz, institutional ownership, INSTOWN, (Hartzell and Starks, 2003), and dedicated institutional ownership, DEDOWN, (Chen et al., 2007). Data from the Thomson Reuters Institutional Holdings (13F) database is used to calculate these two measures. INSTOWN is calculated as the average of the percentages of shares outstanding held by institutional investors over the four quarters of the firm's fiscal year. Following Bushee (1998), $D E D O W N$ is calculated as the yearly percentages of shares outstanding held by dedicated institutional investors, taking the average over the four quarters of the firm's fiscal year.

The sample is divided into those observations having a higher institutional ownership in year $t-l$ above the yearly median value of the measure used (HINSTOWN) and those having a lower institutional ownership in year $t-1$ below or the same as the yearly median value (LINSTOWN). A similar high/low dedicated institutional ownership classification is used for the DEDOWN variable, where $H D E D O W N(L D E D O W N)$ refers to high (low) dedicated institutional holdings. The TAXFEES variable is then interacted with these dummy variables, 
measuring high and low institutional holdings separately, and including both interaction terms in the regression. The results are reported in Table 3.8.

\section{Table 3. 8. Institutional Ownership - APTS and Default Risk}

This table reports the results on how the relationship between auditor provided tax services and default risk varies between high and low institutional ownership. This study uses two measures of institutional ownership: INSTOWN and DEDOWN. For each fiscal year in the sample period, firms are sorted into two groups based on the median value of each of the institutional ownership measures. TAXFEES is interacted with the stronger and weaker institutional ownership dummies and these two interaction variables are regressed on the default risk measure. Appendix 1 provides definitions of all the variables. Standard errors are clustered at firm and year level. Continuous variables are winsorized at the 1 and 99 percent levels. The p-values are shown in brackets. *, **, and $* * *$, indicate statistical significance at the 10,5 , and 1 percent level, respectively.

\begin{tabular}{|c|c|c|}
\hline & \multicolumn{2}{|c|}{ DEFAULT1 } \\
\hline & Column 1 & Column 2 \\
\hline HINSTOWN $x$ TAXFEES $t-1$ & $\begin{array}{l}0.019 * * * \\
(0.002)\end{array}$ & \\
\hline LINSTOWN $x$ TAXFEES $_{t-1}$ & $\begin{array}{l}0.052 * * * \\
(0.000)\end{array}$ & \\
\hline HDEDOWN $x$ TAXFEES ${ }_{t-1}$ & & $\begin{array}{l}0.025 * * * \\
(0.000)\end{array}$ \\
\hline$L D E D O W N \times T_{A X F E E S_{t-1}}$ & & $\begin{array}{l}0.039 * * * \\
(0.000)\end{array}$ \\
\hline LNEQUITY $_{t-1}$ & $\begin{array}{l}-1.183 * * * \\
(0.000)\end{array}$ & $\begin{array}{l}-1.196 * * * \\
(0.000)\end{array}$ \\
\hline$L N D E B T_{t-1}$ & $\begin{array}{l}1.213 * * * \\
(0.000)\end{array}$ & $\begin{array}{l}1.211 * * * \\
(0.000)\end{array}$ \\
\hline$I N V V O L_{t-1}$ & $\begin{array}{l}-0.175^{* * *} \\
(0.000)\end{array}$ & $\begin{array}{l}-0.175 * * * \\
(0.000)\end{array}$ \\
\hline$N I / T A t_{t-1}$ & $\begin{array}{l}-22.05 * * * \\
(0.000)\end{array}$ & $\begin{array}{l}-22.08 * * * \\
(0.000)\end{array}$ \\
\hline$E_{X X E T_{t-1}}$ & $\begin{array}{l}-0.104 \\
(0.297)\end{array}$ & $\begin{array}{l}-0.093 \\
(0.353)\end{array}$ \\
\hline QUOTED $D_{t-1}$ & $\begin{array}{l}46.77 * * * \\
(0.000)\end{array}$ & $\begin{array}{l}48.23 * * * \\
(0.000)\end{array}$ \\
\hline$M T B_{t-1}$ & $\begin{array}{l}-0.663 * * * \\
(0.000)\end{array}$ & $\begin{array}{l}-0.659 * * * \\
(0.000)\end{array}$ \\
\hline $\operatorname{LOSS}_{t-1}$ & $\begin{array}{l}-0.446 \\
(0.111)\end{array}$ & $\begin{array}{l}-0.434 \\
(0.121)\end{array}$ \\
\hline Constant & $\begin{array}{l}-6.565^{* * *} \\
(0.003)\end{array}$ & $\begin{array}{l}-6.500 * * * \\
(0.003)\end{array}$ \\
\hline Difference in Coefficient & $-0.033 * * *$ & -0.014 \\
\hline F-values & 7.20 & 2.19 \\
\hline Year Fixed-Effect & Yes & Yes \\
\hline Industry Fixed-Effect & Yes & Yes \\
\hline R-square & 0.4390 & 0.4387 \\
\hline Adj. R-square & 0.4369 & 0.4366 \\
\hline $\mathrm{N}$ & 21,364 & 21,364 \\
\hline
\end{tabular}


Column 1 of Table 3.8 shows the result for INSTOWN. It shows that the estimated coefficient of TAXFEES is significantly positive (0.019) at the $1 \%$ level for firms that belong to the HINSTOWN grouping and also positive (0.052) at the $1 \%$ level for firms belonging to the LINSTOWN group. However, although both groups have significantly positive relationship between TAXFEES and DEFAULT1, The coefficient for LINSTOWN is more positive than HINSTOWN at the $1 \%$ level. This supports the argument that stronger governance may mitigate the impairment of auditor independence resulting from APTS.

Column 2 of Table 3.8 reports the result for $D E D O W N$. It shows that the estimated coefficient of TAXFEES is significantly positive (0.025) at the $1 \%$ level for firms belonging to $H D E D O W N$ and also significantly positive $(0.039)$ at the $1 \%$ level for firms in the $L D E D O W N$ group. The coefficient of TAXFEES is higher for the LDEDOWN group than the coefficient of TAXFEES for HDEDOWN group but the difference is not significant. This may be related to the condition that as dedicated institutional investors are those, among all investors, who are likely to provide better governance, the groups may not be significantly different in providing the governance mechanism to firms.

\subsection{Information Environment, Auditor Provided Tax Services, and Default}

\section{Risk}

Kim, Krinsky, and Lee (1997) argue that institutional investors are better informed compared to individual investors as their cost unit of gathering information is lower. In addition to their richer information set, institutional investors also have more sophisticated information processing ability (see, for example, Kim and Verrecchia (1994) and Bamber and Cheon (1995)). El-Gazzar 
(1998) finds that higher institutional holding is negatively related to the market reaction to an earnings information release. Further, Jiambalvo, Rajgopal, and Venkatachalam (2002) find that the sophistication of institutional investors leads the current stock price to also reflect forward-looking non-earnings information. Hence, the results presented in Section 3.5 may indicate that the information environment play a significant role in the relationship between APTS and default risk. In this section, this study investigates the influence of the information environment on the relationship between APTS and default risk. It is expected that the positive relationship between TAXFEES and DEFAULT1 is stronger for firms with higher information asymmetry.

Previous studies find that analyst coverage is related to the degree of information asymmetry (see, for example, Roulstone (2003), Frankel and Li (2004), and Chang, Dasgupta, and Hilary (2006)). Roulstone (2003) finds that analyst coverage induces higher public information availability, thereby reducing information asymmetry and increasing market liquidity. Prior studies also use the probability of insider trading, PIN, to capture information asymmetry (see, for example, Akins, Ng, and Verdi (2012) and Bhattacharya, Ecker, Olsson, and Schipper (2012)). Further, Subrahmanyam and Titman (2001) show that higher liquidity increases informational price efficiency by triggering the entry of informed traders. Analyst coverage, PIN, and degree of stock liquidity are thus included to investigate the effect of the information environment on the relationship between TAXFEES and DEFAULT1. 


\subsubsection{Analyst Coverage and Probability of Informed Trading}

Similar to previous studies, Brown and Hillegeist (2007) and Kim, Li, Lu, and $\mathrm{Yu}$ (2016), the information environment is measured by using the number of analyst following the stock (ANALYSTS) and PIN developed by Easley, O'Hara, and Paperman (1998). The analyst coverage measure is calculated using data from the $\mathrm{I} / \mathrm{B} / \mathrm{E} / \mathrm{S}$ database. Analyst following (ANALYSTS) is calculated as the monthly average of analyst following over a 12 month period for a particular firm. The PIN score reflects the probability of an informed trader submitting a certain order and has a positive relationship with the degree of information asymmetry. The annual PIN score measure is provided by Brown and Hillegeist (2007).7 The positive relationship between TAXFEES and DEFAULT1 is expected to be stronger for firms belonging to the lower analyst coverage (higher PIN score) compared to those belonging to the higher analyst coverage (lower PIN score).

To test this conjecture, dummy variables are created based on the degree of information asymmetry measures. In each year, firms are divided into those having a stronger information environment and those having a weaker information environment. In the case of analyst following, there are two dummy variables HANALYSTS and LANALYSTS. HANALYSTS is equal to one for those firms having more analyst following than the median analyst following for each year of the sample and zero otherwise. LANALYSTS is equal to one for those firms having a lower than or equal to yearly median analyst following. A similar high/low informational environment classification is used for the PIN variable,

7 Thanks to Stephen Brown for making the PIN score publicly available at http://scholar.rhsmith.umd.edu/sbrown/pin-data. 
where LPIN (HPIN) refers to a high (low) information environment. TAXFEES is then interacted with those dummy variables, measuring high and low information asymmetry separately, and both interaction terms are included in the regression model.

Table 3.9 provides the results for the effect of the information environment. Column 1 of Table 3.9 presents the results for the information environment measured by ANALYSTS. For firms in the HANALYSTS group, the coefficient is positive (0.014) and significant at 5\% level, and for firms in the LANALYSTS group the coefficient is also positive (0.057) and is significant at the $1 \%$ level. The coefficients are significantly different at $1 \%$ level which indicates that the positive relationship between TAXFEES and DEFAULT1 is stronger for firms with higher information asymmetry.

Column 2 of Table 3.9 presents the results for the information environment as measured by PIN. The results show a positive coefficient $(0.043)$ at $1 \%$ level significance for the relationship between TAXFEES and DEFAULT1 for HPIN group and also a positive coefficient $(0.020)$ at $1 \%$ level of significance for the relationship between TAXFEES and DEFAULT1 for the LPIN group. The coefficient for the HPIN group is higher than for the LPIN group but the difference is not statistically significant. Overall, the results support the prediction that the positive relationship between TAXFEES and DEFAULT1 is stronger for firms belonging to the lower information environment group than for to those that belong to the higher information environment group. 
Table 3. 9. Analyst Following and PIN - APTS and Default Risk

This table reports the results on how the relationship between auditor provided tax services and default risk varies in high and low information environments. This study reports on the information asymmetry measures as follows: in columns 1 and 2, analyst following, ANALYSTS, and probability of informed trading, PIN, respectively. For each fiscal year in the sample period, firms are sorted into two groups based on the median value of each of the information environment measures. TAXFEES is interacted with the stronger and weaker information environment dummies and these two interaction variables are regressed on the default risk measure. The sample for PIN is restricted to 2003 - 2011 due to availability of the data. Appendix 1 provides definitions of all variables. Standard errors are clustered at firm and year level. Continuous variables are winsorized at the 1 and 99 percent levels. The p-values are shown in brackets. *,**, and ***, indicate statistical significance at the 10,5 , and 1 percent level, respectively.

\begin{tabular}{|c|c|c|}
\hline & \multicolumn{2}{|c|}{ DEFAULT1 } \\
\hline & Column 1 & Column 2 \\
\hline HANALYSTS $x$ TAXFEES $t-1$ & $\begin{array}{l}0.014 * * \\
(0.036)\end{array}$ & \\
\hline LANALYSTS $x$ TAXFEES $_{t-1}$ & $\begin{array}{l}0.057 * * * \\
(0.000)\end{array}$ & \\
\hline HPIN $x$ TAXFEES $S_{t-1}$ & & $\begin{array}{l}0.043 * * * \\
(0.009)\end{array}$ \\
\hline LPIN $x$ TAXFEES $_{t-1}$ & & $\begin{array}{l}0.020 * * * \\
(0.005)\end{array}$ \\
\hline $\operatorname{LNEQUITY}_{t-1}$ & $\begin{array}{l}-1.151 \text { *** } \\
(0.000)\end{array}$ & $\begin{array}{l}-1.208 * * * \\
(0.000)\end{array}$ \\
\hline$L N D E B T_{t-1}$ & $\begin{array}{l}1.215^{* * *} \\
(0.000)\end{array}$ & $\begin{array}{l}1.365^{* * *} \\
(0.000)\end{array}$ \\
\hline$I N V V O L_{t-1}$ & $\begin{array}{l}-0.180 * * * \\
(0.000)\end{array}$ & $\begin{array}{l}-0.177 * * * \\
(0.000)\end{array}$ \\
\hline$N I / T A_{t-1}$ & $\begin{array}{l}-22.06 * * * \\
(0.000)\end{array}$ & $\begin{array}{l}-20.37 * * * \\
(0.000)\end{array}$ \\
\hline$E X R E T_{t-1}$ & $\begin{array}{l}-0.133 \\
(0.168)\end{array}$ & $\begin{array}{l}0.008 \\
(0.899)\end{array}$ \\
\hline QUOTED $_{t-1}$ & $\begin{array}{l}48.37 * * * \\
(0.000)\end{array}$ & $\begin{array}{l}43.45^{* * *} \\
(0.000)\end{array}$ \\
\hline$M_{T-1}$ & $\begin{array}{l}-0.653 * * * \\
(0.000)\end{array}$ & $\begin{array}{l}-0.580 * * * \\
(0.000)\end{array}$ \\
\hline $\operatorname{LOSS}_{t-1}$ & $\begin{array}{l}-0.429 \\
(0.127)\end{array}$ & $\begin{array}{l}-0.478 \\
(0.215)\end{array}$ \\
\hline Constant & $\begin{array}{l}-6.848 * * * \\
(0.002)\end{array}$ & $\begin{array}{l}-7.166^{* * *} * \\
(0.002)\end{array}$ \\
\hline Difference in Coefficient & $-0.043 * * *$ & 0.023 \\
\hline F-values & 6.90 & 1.54 \\
\hline Year Fixed-Effect & Yes & Yes \\
\hline Industry Fixed-Effect & Yes & Yes \\
\hline R-square & 0.4393 & 0.4395 \\
\hline Adj. R-square & 0.4371 & 0.4363 \\
\hline $\mathrm{N}$ & 21,364 & 13,308 \\
\hline
\end{tabular}




\subsubsection{Liquidity}

As previous studies find that liquidity is associated with the information environment (see, for example, Welker (1995) and Attig, Fong, Gadhoum, and Lang (2006)), a liquidity measure is also used to capture the quality of the information environment. Three alternative measures are used for illiquidity: (i) the Amihud liquidity measure, AMIHUD, (Amihud, 2002), (ii) the quoted spread, QUOTED, and (iii) the percentage of zero daily returns, ZERO (Lesmond, Ogden, and Trzcinka, 1999). The liquidity measures are calculated using data from the CRSP database. The positive relationship between TAXFEES and DEFAULT1 is expected to be stronger for firms with higher AMIHUD, QUOTED, and ZERO as compared to firms with lower AMIHUD, QUOTED, and ZERO.

As before, all firms in the sample are sorted into two groups based on the median value of the liquidity measures for each year. Specifically, for each of the liquidity measures used, the sample is classified as having low liquidity if AMIHUD, QUOTED, and ZERO are higher than the median value of the particular liquidity measures for each year of the sample and these groups are labeled as HAMIHUD, HQUOTED, and HZERO, respectively. While those having scores lower than or equal to the yearly median value of the respective liquidity measures are labeled as LAMIHUD, LQUOTED, and LZERO. TAXFEES is then interacted with the two binary variables for high and low liquidity separately and both interaction terms are included in the regression.

The results for the liquidity measures of the information environment are reported in Table 3.10. Column 1 shows the results for the AMIHUD measure. It 
Table 3. 10. Liquidity - APTS and Default Risk

This table reports the results on how the relationship between auditor provided tax services and default risk varies in high and low information environments. This study reports on the information asymmetry measures as follows; in columns 1, 2 and 3, Amihud illiquidity, AMIHUD, quote spread, QUOTED, and percentage of daily zero returns, ZERO, respectively. For each fiscal year in the sample period, firms are sorted into two groups based on the median value of each of the information environment measures. TAXFEES is interacted with the stronger and weaker information environment dummies and these two interaction variables are regressed on the default risk measure. Appendix 1 provides definitions of all variables. Standard errors are clustered at firm and year level. Continuous variables are winsorized at the 1 and 99 percent levels. The pvalues are shown in brackets. *,**, and $*^{* *}$, indicate statistical significance at the 10,5 , and 1 percent level, respectively.

\begin{tabular}{|c|c|c|c|}
\hline & \multicolumn{3}{|c|}{ DEFAULT1 } \\
\hline & Column 1 & Column 2 & Column 3 \\
\hline HAMIHUD $x$ TAXFEES $S_{t-1}$ & $\begin{array}{l}0.047 * * * \\
(0.004)\end{array}$ & & \\
\hline LAMIHUD TAXFEES TAI & $\begin{array}{l}0.022 * * * \\
(0.000)\end{array}$ & & \\
\hline HQUOTED $x$ TAXFEES ${ }_{t-1}$ & & $\begin{array}{l}0.054 * * * \\
(0.000)\end{array}$ & \\
\hline LQUOTED TAXFEES TA- & & $\begin{array}{l}0.018 * * * \\
(0.004)\end{array}$ & \\
\hline HZERO $\times$ TAXFEES $S_{t-1}$ & & & $\begin{array}{l}0.066 * * * \\
(0.000)\end{array}$ \\
\hline LZERO TAXFEES $_{t-1}$ & & & $\begin{array}{l}0.013 * * \\
(0.050)\end{array}$ \\
\hline LNEQUITY $_{t-1}$ & $\begin{array}{l}-1.414 * * * \\
(0.000)\end{array}$ & $\begin{array}{l}-1.400 * * * \\
(0.000)\end{array}$ & $\begin{array}{l}-1.389 * * * \\
(0.000)\end{array}$ \\
\hline$L N D E B T_{t-1}$ & $\begin{array}{l}1.260 * * * \\
(0.000)\end{array}$ & $\begin{array}{l}1.257 * * * \\
(0.000)\end{array}$ & $\begin{array}{l}1.254 * * * \\
(0.000)\end{array}$ \\
\hline$I N V V O L_{t-1}$ & $\begin{array}{l}-0.129 * * * \\
(0.000)\end{array}$ & $\begin{array}{l}-0.124 * * * \\
(0.000)\end{array}$ & $\begin{array}{l}-0.136^{* * * *} \\
(0.000)\end{array}$ \\
\hline$N I / T A_{t-1}$ & $\begin{array}{l}-22.18^{* * *} \\
(0.000)\end{array}$ & $\begin{array}{l}-22.17 * * * \\
(0.000)\end{array}$ & $\begin{array}{l}-22.09 * * * \\
(0.000)\end{array}$ \\
\hline EXRET $_{t-1}$ & $\begin{array}{l}-0.011 \\
(0.916)\end{array}$ & $\begin{array}{l}-0.020 \\
(0.851)\end{array}$ & $\begin{array}{l}-0.037 \\
(0.735)\end{array}$ \\
\hline$M B_{t-1}$ & $\begin{array}{l}-0.627 * * * \\
(0.000)\end{array}$ & $\begin{array}{l}-0.626^{* * * *} \\
(0.000)\end{array}$ & $\begin{array}{l}-0.618^{* * * *} \\
(0.000)\end{array}$ \\
\hline $\operatorname{LOSS}_{t-1}$ & $\begin{array}{l}-0.412 \\
(0.138)\end{array}$ & $\begin{array}{l}-0.435 \\
(0.119)\end{array}$ & $\begin{array}{l}-0.446 \\
(0.102)\end{array}$ \\
\hline Constant & $\begin{array}{l}-4.697 * * \\
(0.036)\end{array}$ & $\begin{array}{l}-4.786^{* *} \\
(0.033)\end{array}$ & $\begin{array}{l}-4.734 * * \\
(0.033)\end{array}$ \\
\hline Difference in Coefficient & 0.025 & $0.036^{* *}$ & $0.053 * * *$ \\
\hline F-values & 2.12 & 5.70 & 18.80 \\
\hline Year Fixed-Effect & Yes & Yes & Yes \\
\hline Industry Fixed-Effect & Yes & Yes & Yes \\
\hline R-square & 0.4359 & 0.4363 & 0.4370 \\
\hline Adj. R-square & 0.4338 & 0.4342 & 0.4349 \\
\hline $\mathrm{N}$ & 21,364 & 21,364 & 21,364 \\
\hline
\end{tabular}


shows that the estimated coefficient of TAXFEES is significantly positive $(0.047)$ at $1 \%$ level for firms belongs to the HAMIHUD group and is also positive (0.022) at the $1 \%$ level of significance for firms that belong to the LAMIHUD group. However, while the coefficient for the HAMIHUD group is higher than the coefficient for the LAMIHUD group, the difference is not statistically significant.

Similarly, Column 2 shows that the estimated coefficient of TAXFEES is significantly positive $(0.054)$ at the $1 \%$ level for firms that belong to the HQUOTED group and also positive (0.018) at the $1 \%$ level of significance for firms that belong to LQUOTED. The magnitude of the estimated coefficient of TAXFEES is higher for HQUOTED than LQUOTED at the $5 \%$ level of significance. Column 3 shows that the estimated coefficient of TAXFEES is positive (0.066) at the $1 \%$ level of significance for firms belonging to the HZERO group and is also positive (0.013) at the 5\% level of significance for firms in the LZERO group. The magnitude of the estimated coefficient of TAXFEES is greater for the HZERO group than for the $L Z E R O$ group at the $1 \%$ level of significance.

The results, overall, show that the positive relationship between TAXFEES and DEFAULT1 is stronger for firms that are characterized as having less information availability, irrespective of how the information environment is measured. Overall, the findings indicate that a firm's information environment plays a significant role in determining the relationship between APTS and default risk.

\subsection{Possible Mechanism - Earnings Quality}

The finding that APTS lead to higher default risk is consistent with APTS impairing auditor independence, thereby increasing default risk. To provide 
evidence on a channel through which APTS may induce higher default risk, this study examines the influence of APTS on earnings quality. If APTS lead to lower audit quality as a consequence of impairment of auditor independence, APTS will be associated with lower earnings quality. This conjecture is tested by firstly estimating the following equation:

$\operatorname{RAJGOPALSQ}_{j, t}=\alpha+\beta_{1}$ TAXFEES $_{j, t-1}+\beta_{2}$ Controls $_{j, t-1}+\tilde{\mathrm{e}}_{j, t}$

Earnings quality is measured using squared abnormal accruals (RAJGOPALSQ), as developed in Rajgopal and Venkatachalam (2011). Higher values of RAJGOPALSQ indicate lower earnings quality. MTB is included to control for firms with higher asset valuations being more likely to have lower earnings quality, GROWTH to mitigate the influence that firms in high growth phase have less scope to manage earnings, LNTA to control the effect of bigger firms being less likely to manage earnings, $L E V E R A G E$ to mitigate the effect that firms with higher debt capital having more incentive to manage earnings in order to meet debt covenants, and LOSS to mitigate the effect of experiencing loss.

Table 3.11 shows the result of estimation of equation (3.5). The positive coefficient of 0.001 at $5 \%$ level of significance on TAXFEES shows that TAXFEES is positively related to RAJGOPALSQ. For the control variables, as expected, lower earnings quality is related to lower growth, higher asset valuation, smaller firm size, higher leverage, and higher loss experience. Thus APTS are associated with lower earnings quality. This result lends supporting evidence to the baseline result that APTS induce higher default risk due to the impairment of auditor independence. 


\section{Table 3. 11. Earnings Quality Channel - APTS and Default Risk}

This table reports the relationship between auditor provided tax services, earnings quality, and default risk. It shows the influence of auditor provided tax services on earnings quality. Earnings quality is measured by RAJGOPALSQ. Appendix 1 provides definitions of variables. Continuous variables are winsorized at the 1 and 99 percent levels. Standard errors are clustered at firm and year level. The p-values are shown in brackets. *, **, and ***, indicate statistical significance at the 10,5 , and 1 percent level, respectively.

\begin{tabular}{|c|c|}
\hline & RAJGOPALSQ \\
\hline TAXFEES $_{t-1}$ & $\begin{array}{l}0.001 * * * \\
(0.001)\end{array}$ \\
\hline GROWTH $_{t-1}$ & $\begin{array}{l}-0.001 * * * \\
(0.006)\end{array}$ \\
\hline$M T B_{t-1}$ & $\begin{array}{l}0.001 * * * \\
(0.000)\end{array}$ \\
\hline$L_{N T A_{t-1}}$ & $\begin{array}{l}-0.002^{* * * *} \\
(0.000)\end{array}$ \\
\hline$L E V E R A G E_{t-1}$ & $\begin{array}{l}0.001 * * * \\
(0.001)\end{array}$ \\
\hline $\operatorname{LOSS}_{t-1}$ & $\begin{array}{l}0.002 * * * \\
(0.000)\end{array}$ \\
\hline Constant & $\begin{array}{l}0.011 * * * \\
(0.000)\end{array}$ \\
\hline Year Fixed-Effect & Yes \\
\hline Industry Fixed-Effect & Yes \\
\hline R-square & 0.0995 \\
\hline Adj. R-square & 0.0963 \\
\hline $\mathrm{N}$ & 20,880 \\
\hline
\end{tabular}

To confirm the earnings quality channel, this study investigates the impact of RAJGOPALSQ on DEFAULT1. To do so, the following equation is estimated:

$$
\text { DEFAULT }_{j, t}=\alpha+\beta_{1} \text { RAJGOPALSQ } Q_{j, t}+\beta_{2} \text { Controls }_{j, t-1}+\mathrm{e}_{j, t}
$$

The results are reported in Table 3.12. It shows that default risk increases when earnings quality declines. Overall, the findings in this section lend support to the hypothesis that APTS increase default risk by impairing auditor independence which is reflected in decreased earnings quality. 
Table 3. 12. Earnings Quality Channel - APTS and Default Risk - Confirmatory Tests

This table reports the relationship between auditor provided tax services, earnings quality, and default risk. It shows the influence of earnings quality on default risk. Earnings quality is measured by RAJGOPALSQ. Appendix 1 provides definitions of variables. Continuous variables are winsorized at the 1 and 99 percent levels. Standard errors are clustered at firm and year level. The p-values are shown in brackets. *,**, and ***, indicate statistical significance at the 10,5 , and 1 percent level, respectively.

\begin{tabular}{|c|c|}
\hline & DEFAULT1 \\
\hline$R A J G O P A L S Q_{t}$ & $\begin{array}{l}57.56 * * * \\
(0.000)\end{array}$ \\
\hline LNEQUITY $Y_{t-1}$ & $\begin{array}{l}-1.116^{* * * *} \\
(0.000)\end{array}$ \\
\hline$L_{N D E B T_{t-1}}$ & $\begin{array}{l}1.196 * * * \\
(0.000)\end{array}$ \\
\hline$I_{N V V O L t-1}$ & $\begin{array}{l}-0.179 * * * \\
(0.000)\end{array}$ \\
\hline$N I / T A_{t-1}$ & $\begin{array}{l}-21.38 * * * \\
(0.000)\end{array}$ \\
\hline $\operatorname{EXRET}_{t-1}$ & $\begin{array}{l}-0.090 \\
(0.399)\end{array}$ \\
\hline QUOTED $_{t-1}$ & $\begin{array}{l}42.15 * * * \\
(0.000)\end{array}$ \\
\hline$M_{T B}{ }_{t-1}$ & $\begin{array}{l}-0.732 * * * \\
(0.000)\end{array}$ \\
\hline $\operatorname{LOSS}_{t-1}$ & $\begin{array}{l}-0.356 \\
(0.197)\end{array}$ \\
\hline Constant & $\begin{array}{l}-6.854 * * * \\
(0.003)\end{array}$ \\
\hline Year Fixed-Effect & Yes \\
\hline Industry Fixed-Effect & Yes \\
\hline $\mathrm{R}$-square & 0.4439 \\
\hline Adj. R-square & 0.4418 \\
\hline $\mathrm{N}$ & 20,880 \\
\hline
\end{tabular}

As a robustness check for this earnings quality channel, this study estimates the following equation:

$$
\begin{aligned}
\operatorname{DEFAULT1}_{j, t}= & \alpha+\beta_{1} \text { TAXFEES }_{j, t-1}+\beta_{2} \text { TAXFEES }_{j, t-1} * \\
& \text { RAJGOPALSQ } Q_{j, t}+\beta_{3} \text { Controls }_{j, t-1}+ \\
& \mathrm{e}_{j, t}
\end{aligned}
$$

The results are reported in Table 3.13. The positive coefficient of 0.013, at $5 \%$ level of significance, on TAXFEES shows that TAXFEES is positively related 
to DEFAULT1. The coefficient on the interaction between TAXFEES and RAJGOPALSQ is also positive (2.967), at $1 \%$ level of significance, which shows that earnings quality adds to the impact of TAXFEES on DEFAULT1.

Table 3. 13. Earnings Quality Channel - APTS and Default Risk - Additional Test This table reports the relationship between auditor provided tax services, earnings quality, and default risk. Appendix 1 provides definitions of variables. Continuous variables are winsorized at the 1 and 99 percent levels. Standard errors are clustered at firm and year level. The $\mathrm{p}$-values are shown in brackets. $*, * *$, and $* * *$, indicate statistical significance at the 10,5 , and 1 percent level, respectively.

\begin{tabular}{|c|c|}
\hline & $\overline{D E F A U L T 1}$ \\
\hline TAXFEES $_{t-1}$ & $\begin{array}{l}0.013^{* *} \\
(0.044)\end{array}$ \\
\hline$R A J G O P A L S Q_{t}$ & $\begin{array}{l}36.85 * * * \\
(0.000)\end{array}$ \\
\hline TAXFEES $_{t-l} * R_{A J G O P A L S Q} Q_{t}$ & $\begin{array}{l}2.967 * * * \\
(0.000)\end{array}$ \\
\hline$L_{N E Q U I T Y_{t-1}}$ & $\begin{array}{l}-1.133^{* * * *} \\
(0.000)\end{array}$ \\
\hline$L N D E B T_{t-1}$ & $\begin{array}{l}1.192 * * * \\
(0.000)\end{array}$ \\
\hline$I_{N V V O L t-1}$ & $\begin{array}{l}-0.177 * * * \\
(0.000)\end{array}$ \\
\hline$N I / T A_{t-1}$ & $\begin{array}{l}-21.35^{* * *} \\
(0.000)\end{array}$ \\
\hline $\operatorname{EXRET}_{t-1}$ & $\begin{array}{l}-0.078 \\
(0.468)\end{array}$ \\
\hline QUOTED $_{t-1}$ & $\begin{array}{l}41.82 * * * \\
(0.000)\end{array}$ \\
\hline$M_{T-1}$ & $\begin{array}{l}-0.728 * * * \\
(0.000)\end{array}$ \\
\hline $\operatorname{LOSS}_{t-1}$ & $\begin{array}{l}-0.355 \\
(0.203)\end{array}$ \\
\hline Constant & $\begin{array}{l}-6.973 * * * \\
(0.002)\end{array}$ \\
\hline Year Fixed-Effect & Yes \\
\hline Industry Fixed-Effect & Yes \\
\hline $\mathrm{R}$-square & 0.4454 \\
\hline Adj. R-square & 0.4432 \\
\hline $\mathrm{N}$ & 20,880 \\
\hline
\end{tabular}

\subsection{Conclusion}

This study finds that APTS have a significant positive relationship with default risk. The results, therefore, support H1(b) that APTS have a positive association with default risk. The result holds after addressing potential 
endogeneity and is robust to (i) excluding the global financial crisis period from the dataset and (ii) alternative measures of default risk. The positive relationship between APTS and default risk is stronger for firms with lower institutional holdings. This may provide evidence that stronger corporate governance may mitigate the positive relationship between APTS and default risk. The higher the degree of information asymmetry, as reflected by lower analyst following, higher probability of informed trading, and lower stock liquidity, the stronger is the positive relationship between APTS and default risk. This indicates that a firm's information environment plays a significant role in determining the relationship between APTS and default risk.

Furthermore, this study finds that APTS lead to higher default risk through the deterioration of earnings quality. Specifically, this study finds that APTS are related to lower earnings quality. This, therefore, indicates that APTS lower auditor independence and audit quality, thereby lowering earnings quality and increasing default risk. 


\section{CHAPTER FOUR}

\section{CONCLUSION TO THE THESIS}

This study examines the impact of APTS on capital markets. First, it uses the Dyreng and Markle (2016) income shifting measurement model to examine the impact of APTS on income shifting by U.S. multinational companies. Second, it uses a large broad sample of U.S. firms to investigate the impact of APTS on default risk. This chapter is structured as follows. Section 4.1 presents the summary of the research findings on the impact of APTS. Section 4.2 summarises the contributions from this study. Section 4.3 notes the limitations of the study. Finally, Section 4.4 offers suggestions for future research.

\subsection{Summary of Findings}

There are contrasting arguments on the influence of APNAS on the work of auditors. APNAS may provide knowledge spillovers which improve the auditor's understanding of the client and thereby increases the quality of the work performed. However, the opponents of APNAS claim that APNAS may impair the independence of auditors, thereby lowering the quality of the work of the auditor. Regulators have been concerned about the possibility that APNAS do impair auditor independence. As a result, SEC banned several, previously allowed, APNAS such as bookkeeping and financial information systems design and implementation but have continued to permit auditors to provide tax services to their clients.

The evidence from empirical studies on APNAS and, specifically, APTS, is mixed. Therefore, for both income shifting and default risk this study proposes 
two hypotheses, one that APTS increase the phenomenon of interest, the other that APTS decrease it.

For income shifting, this study tests the hypotheses using a sample of 10,248 firm-year observations on U.S. multinationals over the period $2002-2016$ and employs the Dyreng and Markle (2016) income shifting measurement model, originally developed to test the impact of financial constraints on income shifting. The test focuses on outbound shifting as estimates of inbound shifting are subject to severe noise. This study finds that APTS reduce outbound income shifting. The result holds after addressing potential endogeneity and is robust to excluding observations from the financial crisis periods. The result also holds when firm specific characteristics are included in the equations for the income shifting parameters.

For default risk, this study tests the hypotheses using a sample of 21,364 firm-year observations on a broad sample of U.S. firms over the period 2003 2016. The test model states a simple link from a measure of APTS to a measure of default risk, subject to controls. This study measures APTS by scaled fees for APTS and default risk by the modified Altman Z-score. APTS are found to have a positive relationship with default risk. The result holds after addressing potential endogeneity and is robust to excluding the global financial crisis period and use of alternative measures of default risk (the initial Altman Z-score and the expected default frequency). This study also finds that the positive relationship is stronger with lower institutional holdings. This suggests that stronger corporate governance may mitigate the impact of APTS on default risk. It also finds that the impact of APTS on default risk is stronger with a higher degree of information 
asymmetry. Finally, this study finds evidence that earnings quality may be the channel for the influence of APTS on default risk. That is, APTS lower audit quality, thereby lowering earnings quality and increasing default risk. Given the cost of default, this is an important finding.

The examination of the impact of APTS on the two capital markets phenomena indicates that the effects are opposite in direction. Thus, taking the results on income shifting and default risk in combination, the issue of the SEC continuing to permit auditors to provide tax services is left open to question.

One obvious possible reason for the finding of opposite effects is simply that income shifting relates to just a segment of all U.S. firms whereas default risk applies for all U.S. firms. It is not unusual to find in empirical research that a particular effect is different across different populations of firms or across different time periods. It may be that the difference results from differing degrees of importance for audit as a governance mechanism. In the case of income shifting the auditor is probably the only external party with a detailed knowledge of income shifting arrangements and therefore plays a key role in managing the risks associated with entering into such arrangements. Furthermore because of the larger size of multinationals, the auditor may provide a higher level of quality in audit services. For default risk, a number of non-audit governance mechanisms may mitigate the impact of APTS as indicated by the tests on institutional holdings and the information environment.

\subsection{Contributions}

Section 4.2.1 discusses the contributions generated from examination of the relationship between APTS and income shifting. Section 4.2.2 presents the 
contributions resulting from examination of the relationship between APTS and default risk.

\subsubsection{Contributions: APTS and Income Shifting}

The contributions from the investigation of the influence of APTS on income shifting include the following: First, while large number of earlier studies have investigated APTS and income shifting separately, none has tested, as this study does, the possible link between them. Second, this study presents additional evidence on companies' tax avoidance behaviour. The prior literature shows that tax avoidance by companies is influenced by manager type, firm factors, and country factors. This study extends this line of research by providing evidence on the influence of an additional party, namely the auditor as a tax consultant. Third, this study finds that APTS reduce income shifting. This is an important finding as income shifting is a significant economic issue. The OECD (OECD, 2015) estimates that tax avoidance activities reduce global tax revenue by $4 \%$ to $10 \%$, and income shifting is likely to be a leading factor for this result. However, while the finding on APTS appears to be supportive of the SEC's stance, this is tempered by the finding on the impact of APTS on default risk.

\subsubsection{Contributions: APTS and Default Risk}

By examining the influence of APTS on default risk, this study makes a number of contributions. First, as with the examination of APTS and income shifting, a large number of studies have considered separately APTS and default risk but this is the first study to link them. Second, this study finds that APTS lead to higher default risk for firms with lower institutional holdings and higher information asymmetry. This may indicate the importance of other corporate 
governance mechanisms to mitigate the negative effect of APTS on audit quality. Third, this study finds that APTS are associated with lower earnings quality and thus earnings quality may be a channel for the impact of APTS on default risk.

The finding on the impact of APTS on income shifting suggests that APTS improves the auditor's understanding of the client and thereby increases the quality of the work performed. However, the finding on the impact of APTS on default risk suggests that APTS may impair the independence of auditors. Therefore, the issue of the SEC continuing to permit auditors to provide tax services remains an open question.

\subsection{Limitations}

Section 4.3.1 presents the limitations in the examination of the relationship between APTS and income shifting. Section 4.3.2 presents the limitations in the examination of the relationship between APTS and default risk.

\subsubsection{Limitations: APTS and Income Shifting}

A key limitation of this study is the data used. Specifically, the study uses publicly available financial statement data. As regards taxation per se this is unlikely to be the same as the data provided in tax returns. Clearly, the latter data are not publicly available. However, a saving factor is that such data is unavailable not just to researchers but also to the market. Thus the study at least uses the same data as that guiding market behaviour. An additional limitation arises from the use of the Dyreng and Markle (2016) income shifting model, which relies on a number of assumptions, the effect of which is inevitably uncertain. Finally, as with all empirical studies, it may suffer from significant omitted variables. 


\subsubsection{Limitations: APTS and Default Risk}

A significant limitation on this study is in the definition and measurement of default risk. The measures used are well established in the literature but serve a wide range of different forms of distress. Several prior studies find that audit committee characteristics influence the impact of APNAS. This study omits consideration of the role of the audit committee in the decision to employ the auditor to provide tax services. As with the study on APTS and income shifting, this study may also suffer from significant omitted variables.

\subsection{Future Research}

The following issues could benefit from further research. In general, there should be further consideration of the audit as a governance mechanism, in a portfolio of governance mechanisms, and therefore the degree of impact of the other mechanisms on the consequence of extending the role of auditor to include tax advice. This is a vast area for research but in the case of default risk, this study has considered the relationship with one such mechanism, viz, institutional holdings. Particular issues to be investigated include the characteristics of the audit committee in selecting between the auditor and other parties for providing tax advice, and whether the tax services are recurring or non-recurring. 


\section{REFERENCES}

Abbott, L. J., Parker, S., Peters, G. F., \& Raghunandan, K. (2003). An Empirical Investigation of Audit Fees, Nonaudit Fees, and Audit Committees. Contemporary Accounting Research, 20, 215-234.

Akins, B. K., Ng, J., \& Verdi, R. S. (2012). Investor Competition over Information and the Pricing of Information Asymmetry. The Accounting Review, 87, 35-58.

Altman, E. I. (1968). Financial Ratios, Discriminant Analysis and the Prediction of Corporate Bankruptcy. The Journal of Finance, 23, 589-609.

Altman, E. I. (1983). Corporate financial distress: a complete guide to predicting, avoiding, and dealing with bankruptcy. Wiley, New York

Amihud, Y. (2002). Illiquidity and stock returns: cross-section and time-series effects. Journal of Financial Markets, 5, 31-56.

Antle, R., Gordon, E., Narayanamoorthy, G., \& Zhou, L. (2006). The joint determination of audit fees, non-audit fees, and abnormal accruals. Review of Quantitative Finance and Accounting, 27, 235-266.

Armstrong, C. S., Guay, W. R., \& Weber, J. P. (2010). The role of information and financial reporting in corporate governance and debt contracting. Journal of Accounting and Economics, 50, 179-234.

Attig, N., Fong, W.-M., Gadhoum, Y., \& Lang, L. H. P. (2006). Effects of large shareholding on information asymmetry and stock liquidity. Journal of Banking \& Finance, 30, 2875-2892. 
Bamber, L. S., \& Cheon, Y. S. (1995). Differential Price and Volume Reactions to Accounting Earnings Announcements. The Accounting Review, 70, $417-441$.

Barefoot, K. B., \& Mataloni, J. R. J. (2011). Operations of U.S. Multinational Companies in the United States and Abroad: Preliminary Results From the 2009 Benchmark Survey. Survey of Current Business, 91, 29-55.

Basel Committee on Banking Supervision. (1999). Credit Risk Modelling: Current Practices and Applications. Retrieved January 9, 2018, from https://www.bis.org/publ/bcbs49.htm

Bennett, R. L., Güntay, L., \& Unal, H. (2015). Inside debt, bank default risk, and performance during the crisis. Journal of Financial Intermediation, 24, $487-513$.

Berger, P. G., \& Hann, R. (2003). The Impact of SFAS No. 131 on Information and Monitoring. Journal of Accounting Research, 41, 163-223.

Bharath, S. T., \& Shumway, T. (2008). Forecasting Default with the Merton Distance to Default Model. The Review of Financial Studies, 21, 13391369.

Bhattacharya, N., Ecker, F., Olsson, P. M., \& Schipper, K. (2012). Direct and Mediated Associations among Earnings Quality, Information Asymmetry, and the Cost of Equity. The Accounting Review, 87, 449482.

Brogaard, J., Li, D., \& Xia, Y. (2017). Stock liquidity and default risk. Journal of Financial Economics, 124, 486-502. 
Brown, S., \& Hillegeist, S. A. (2007). How Disclosure Quality Affects the Level of Information Asymmetry. Review of Accounting Studies, 12, 443477.

Bushee, B. J. (1998). The influence of institutional investors in myopic R\&D investment behavior. The Accounting Review, 73, 305-333.

Chang, X., Dasgupta, S., \& Hilary, G. (2006). Analyst Coverage and Financing Decisions. The Journal of Finance, 61, 3009-3048.

Chen, X., Harford, J., \& Li, K. (2007). Monitoring: Which institutions matter?. Journal of Financial Economics, 86, 279-305.

Clausing, K. A. (2009). Multinational Firm Tax Avoidance and Tax Policy. National Tax Journal, 62, 703-725.

Collins, J., Kemsley, D., \& Lang, M. (1998). Cross-Jurisdictional Income Shifting and Earnings Valuation. Journal of Accounting Research, 36, 209-229.

Cook, K. A., Huston, G. R., \& Omer, T. C. (2008). Earnings Management through Effective Tax Rates: The Effects of Tax-Planning Investment and the Sarbanes-Oxley Act of 2002. Contemporary Accounting Research, 25, $447-471$.

Davydenko, S. A., Strebulaev, I. A., \& Zhao, X. (2012). A Market-Based Study of the Cost of Default. The Review of Financial Studies, 25, 2959-2999.

De Simone, L., Ege, M. S., \& Stomberg, B. (2015). Internal Control Quality: The Role of Auditor Provided Tax Services. The Accounting Review, 90, $1469-1496$.

Devereux, M. P., \& Griffith, R. (2003). Evaluating Tax Policy for Location Decisions. International Tax and Public Finance, 10, 107-126. 
Dharmapala, D., \& Riedel, N. (2013). Earnings shocks and tax-motivated incomeshifting: Evidence from European multinationals. Journal of Public Economics, 97, 95-107.

Dyreng, S. D., Hanlon, M., \& Maydew, E. L. (2008). Long-Run Corporate Tax Avoidance. The Accounting Review, 83, 61-82.

Dyreng, S. D., \& Markle, K. S. (2016). The Effect of Financial Constraints on Income Shifting by U.S. Multinationals. The Accounting Review, 91, $1601-1627$.

Easley, D., O’Hara, M., \& Paperman, J. (1998). Financial analysts and information-based trade. Journal of Financial Markets, 1, 175-201.

Edwards, A., Schwab, C., \& Shevlin, T. (2016). Financial Constraints and Cash Tax Savings. The Accounting Review, 91, 859-881.

Eidleman, G. J. (1995). Z scores - a guide to failure prediction. The CPA Journal, $65,52-$.

El-Gazzar, S. M. (1998). Predisclosure information and institutional ownership: A cross-sectional examination of market revaluations during earnings announcement periods. The Accounting Review, 73, 119-129.

Ferguson, M. J., Seow, G. S., \& Young, D. (2004). Nonaudit Services and Earnings Management: UK Evidence. Contemporary Accounting Research, 21, 813-841.

Fernandes, N., \& Ferreira, M. A. (2009). Insider Trading Laws and Stock Price Informativeness. The Review of Financial Studies, 22, 1845-1887. 
Fortin, S., \& Pittman, J. A. (2008). The Impact of Auditor-Related Tax Services on Corporate Debt Pricing. Journal of the American Taxation Association, 30, 79-106.

Francis, J. R., \& Ke, B. (2006). Disclosure of fees paid to auditors and the market valuation of earnings surprises. Review of Accounting Studies, 11, 495523.

Frankel, R., \& Li, X. (2004). Characteristics of a firm's information environment and the information asymmetry between insiders and outsiders. Journal of Accounting and Economics, 37, 229-259.

Frankel, R. M., Johnson, M. F., Nelson, K. K., Kinney, J., \& Libby, R. (2002). The relation between auditors' fees for nonaudit services and earnings management. The Accounting Review, 77, 71-114.

Gaynor, L. M., McDaniel, L. S., \& Neal, T. L. (2006). The Effects of Joint Provision and Disclosure of Nonaudit Services on Audit Committee Members' Decisions and Investors' Preferences. The Accounting Review, 81, 873-896.

Giesecke, K., Longstaff, F. A., Schaefer, S., \& Strebulaev, I. (2011). Corporate bond default risk: A 150-year perspective. Journal of Financial Economics, 102, 233-250.

Gleason, C. A., \& Mills, L. F. (2011). Do Auditor-Provided Tax Services Improve the Estimate of Tax Reserves?. Contemporary Accounting Research, $28,1484-1509$. 
Gleason, C. A., Mills, L. F., \& Nessa, M. L. (2018). Does FIN 48 Improve Firms' Estimates of Tax Reserves?. Contemporary Accounting Research, 35, $1395-1429$.

Glover, B. (2016). The expected cost of default. Journal of Financial Economics, 119, 284-299.

Goyal, V. K., \& Wang, W. (2013). Debt Maturity and Asymmetric Information: Evidence from Default Risk Changes. The Journal of Financial and Quantitative Analysis, 48, 789-817.

Hartzell, J. C., \& Starks, L. T. (2003). Institutional Investors and Executive Compensation. The Journal of Finance, 58, 2351-2374.

Heckman, J. J. (1979). Sample Selection Bias as a Specification Error. Econometrica (Pre-1986); Evanston, 47, 153-161.

Hsu, P. H., Lee, H. H., Liu, A. Z., \& Zhang, Z. (2015). Corporate innovation, default risk, and bond pricing. Journal of Corporate Finance, 35, 329344.

Jiambalvo, J., Rajgopal, S., \& Venkatachalam, M. (2002). Institutional ownership and the extent to which stock prices reflect future earnings. Contemporary Accounting Research; Toronto, 19, 117-145.

Kim, J. B., Krinsky, I., \& Lee, J. (1997). Institutional Holdings and Trading Volume Reactions to Quarterly Earnings Announcements. Journal of Accounting, Auditing \& Finance, 12, 1-14.

Kim, J. B., Li, L., Lu, L. Y., \& Yu, Y. (2016). Financial statement comparability and expected crash risk. Journal of Accounting and Economics, 61, 294-312. 
Kim, O., \& Verrecchia, R. E. (1994). Market liquidity and volume around earnings announcements. Journal of Accounting and Economics, 17, $41-67$.

Kinney, W. R., Palmrose, Z. V., \& Scholz, S. (2004). Auditor Independence, Non-Audit Services, and Restatements: Was the U.S. Government Right?. Journal of Accounting Research, 42, 561-588.

Klassen, K. J., \& Laplante, S. K. (2012a). Are U.S. Multinational Corporations Becoming More Aggressive Income Shifters? Journal of Accounting Research, 50, 1245-1285.

Klassen, K. J., \& Laplante, S. K. (2012b). The Effect of Foreign Reinvestment and Financial Reporting Incentives on Cross-Jurisdictional Income Shifting. Contemporary Accounting Research, 29, 928-955.

Klassen, K. J., Lisowsky, P., \& Mescall, D. (2016). The Role of Auditors, NonAuditors, and Internal Tax Departments in Corporate Tax Aggressiveness. The Accounting Review, 91, 179-205.

Krishnan, G. V., \& Visvanathan, G. (2011). Is There an Association between Earnings Management and Auditor-Provided Tax Services? Journal of the American Taxation Association, 33, 111-135.

Krishnan, G. V., Visvanathan, G., \& Yu, W. (2013). Do Auditor-Provided Tax Services Enhance or Impair the Value Relevance of Earnings? Journal of the American Taxation Association, 35, 1-19.

Krishnan, J., Sami, H., \& Zhang, Y. (2005). Does the Provision of Nonaudit Services Affect Investor Perceptions of Auditor Independence?. Auditing: A Journal of Practice \& Theory, 24, 111-135. 
Lassila, D. R., Omer, T. C., Shelley, M. K., \& Smith, L. M. (2010). Do

Complexity, Governance, and Auditor Independence Influence whether

Firms Retain Their Auditors for Tax Services? Journal of the American

Taxation Association, 32, 1-23.

Lesmond, D. A., Ogden, J. P., \& Trzcinka, C. A. (1999). A New Estimate of Transaction Costs. The Review of Financial Studies, 12, 1113-1141.

Liao, H. H., Chen, T. K., \& Lu, C. W. (2009). Bank credit risk and structural credit models: Agency and information asymmetry perspectives. Journal of Banking \& Finance, 33, 1520-1530.

Lisic, L. L. (2014). Auditor-Provided Tax Services and Earnings Management in Tax Expense: The Importance of Audit Committees. Journal of Accounting, Auditing \& Finance, 29, 340-366.

Maydew, E., and Shackelford, D. (2007). The changing role of auditors in corporate tax planning. In: Auerbach, A., Hines, J., Slemrod, J. (Eds.), Taxing Corporate Income in the 21st Century. Cambridge University Press, New York, NY, pp. $307-337$.

McGuire, S. T., Omer, T. C., \& Wang, D. (2012). Tax Avoidance: Does TaxSpecific Industry Expertise Make a Difference?. The Accounting Review, 87, 975-1003.

Merton, R. C. (1974). On the Pricing of Corporate Debt: The Risk Structure of Interest Rates. The Journal of Finance, 29, 449-470.

Omer, T. C., Bedard, J. C., \& Falsetta, D. (2006). Auditor-Provided Tax Services: The Effects of a Changing Regulatory Environment. The Accounting Review, 81, 1095-1117. 
Organisation for Economic Co-operation and Development (OECD). (2015).

OECD/G20 Base Erosion and Profit Shifting Project. Available at: http://www.oecd.org/ctp/beps-explanatory-statement-2015.pdf.

Paterson, J. S., \& Valencia, A. (2011). The Effects of Recurring and Nonrecurring Tax, Audit-Related, and Other Nonaudit Services on Auditor Independence: Effects of Recurring and Nonrecurring Nonaudit Services. Contemporary Accounting Research, 28, 1510-1536.

Public Company Accounting Oversight Board (PCAOB). (2004). Auditor Independence Tax Services Roundtable. Available at: http://pcaobus.org/Rules/Rulemaking/Docket017/2004-0714_Roundtable_Transcript.pdf

Rajgopal, S., \& Venkatachalam, M. (2011). Financial reporting quality and idiosyncratic return volatility. Journal of Accounting and Economics, $51,1-20$.

Rego, S. O. (2003). Tax-Avoidance Activities of U.S. Multinational Corporations. Contemporary Accounting Research, 20, 805-833.

Robinson, D. (2008). Auditor Independence and Auditor-Provided Tax Service: Evidence from Going-Concern Audit Opinions Prior to Bankruptcy Filings. Auditing, 27, 31-54.

Roulstone, D. T. (2003). Analyst Following and Market Liquidity. Contemporary Accounting Research, 20, 552-578.

Seetharaman, A., Sun, Y., \& Wang, W. (2011). Tax-Related Financial Statement Restatements and Auditor-Provided Tax Services. Journal of Accounting, Auditing \& Finance, 26, 677-698. 
Simunic, D. A. (1980). The Pricing of Audit Services: Theory and Evidence. Journal of Accounting Research, 18, 161-190.

Simunic, D. A. (1984). Auditing, Consulting, and Auditor Independence. Journal of Accounting Research, 22, 679-702.

Subrahmanyam, A., \& Titman, S. (2001). Feedback from Stock Prices to Cash Flows. The Journal of Finance, 56, 2389-2413.

Vassalou, M., \& Xing, Y. (2004). Default Risk in Equity Returns. The Journal of Finance, 59, 831-868.

Welker, M. (1995). Disclosure policy, information asymmetry, and liquidity in equity markets. Contemporary Accounting Research, 11, 801-827. 


\section{APPENDIX 1 - DEFINITION OF VARIABLES}

Variable Name Definitions

\section{Key Dependent Variable}

DEFAULT1 Modified Altman Z-score (Altman, 1983). Altman Z-Score

formula is calculated as in Edwards et al. (2016). The

formula stated in page 67 , restated in term of Compustat data items, is as follows:

$6.72 *((\mathrm{PI}+\mathrm{XINT}) / \mathrm{AT})+6.56 *(\mathrm{WCAP} / \mathrm{AT})+$

$3.26 *(\mathrm{RE} / \mathrm{AT})+1.05 *\left(\left(\mathrm{CHSO} * \mathrm{PRCC} \_\mathrm{F}\right) / \mathrm{LT}\right)$.

DEFAULT2 Original Altman Z-score (Altman, 1968). Altman Z-Score

formula is calculated as in Edwards et al. (2016). The

formula stated in page 81 , restated in term of Compustat data items, is as follows:

$3.3 *((\mathrm{PI}+\mathrm{XINT}) / \mathrm{AT})+1.2 *(\mathrm{WCAP} / \mathrm{AT})+(\mathrm{SALE} / \mathrm{AT})+$ $1.4 *(\mathrm{RE} / \mathrm{AT})+0.6^{*}\left(\left(\mathrm{CHSO} * \mathrm{PRCC} \_\mathrm{F}\right) / \mathrm{LT}\right)$.

$E D F$

Expected default frequency (Bharath and Shumway 2008, and Brogaard et al. 2017).

TAXFEES

The ratio of auditor tax fees (in thousand) scaled by total assets.

ATS

An indicator variable equal to one if firm's auditor tax fee is above the yearly median of sample firms and zero otherwise

Other Variables

$\sigma E($ VOLATILITY $)$ Annualized stock return volatility.

$\triangle P I F O \quad$ (Foreign earnings in year $\mathrm{t}-$ foreign earnings in year $\mathrm{t}-1$ ), 
scaled by total assets in year $\mathrm{t}-1$.

$\triangle P I D O M$

(Domestic earnings in year $\mathrm{t}-$ domestic earnings in year $\mathrm{t}-$

1), scaled by total assets in year $\mathrm{t}-1$.

$\triangle S A L E F O \quad$ (Foreign sales in year $\mathrm{t}$ - foreign sales in year $\mathrm{t}-1$ ), scaled by total assets in year $\mathrm{t}-1$.

$\triangle S A L E D O M \quad$ (Domestic sales in year $\mathrm{t}-$ domestic sales in year $\mathrm{t}-1$ ), scaled by total assets in year $\mathrm{t}-1$.

ADVEXP The ratio of advertising expense on total sales.

AMIHUD Stock Illiquidity, defines as an average ratio of the daily absolute return to the (dollar) trading volume on that day, giving the absolute (percentage) price change per dollar of daily trading volume, or the daily price impact of the order flow (multiplied by100,000 for presentation).

ANALYSTS The monthly average of analyst following over a 12 month period.

AUDCHANGE An indicator variable equal to one if the firm changed its auditor from the prior year, and zero otherwise.

AUDFEES Natural logarithm of audit fees.

AUDINDEP The ratio of non-audit fees less tax fees to audit fees.

AUDTENURE Number of years the firm has been audited by the same auditor.

CAPINT The ratio of net property, plant, and equipment to lagged total assets.

CTA The ratio of cash to total assets. 
$D E B T$

DEDOWN

DTA

EQUITY

EXRET

FTS

GROWTH

HAMIHUD

HDEDOWN

HINSTOWN

HQUOTED
Face value of debt, computed as the sum of debt in current liabilities and one-half of long-term debt.

The yearly percentages of shares outstanding held by

dedicated institutional investors, taking the average over the four quarters of the firm's fiscal year.

The ratio of long-term debt to total assets.

Number of shares outstanding multiplied by share price at the end of year.

Annual excess return, calculated as the difference between company stock return and market return in the same year. The ratio of foreign sales to total sales.

Total assets in year $\mathrm{t} /$ total assets in year $\mathrm{t}-1$ deflated by total assets in year $\mathrm{t}-1$.

Dummy variable takes value of one if $A M I H U D$ is greater than its median value, and zero otherwise.

Dummy variable takes value of one if ANALYSTS is greater than its median value, and zero otherwise.

Dummy variable takes value of one if $D E D O W N$ is greater than its median value, and zero otherwise.

Dummy variable takes value of one if INSTOWN is greater than its median value, and zero otherwise.

Dummy variable takes value of one if PIN is greater than its median value, and zero otherwise.

Dummy variable takes value of one if $Q U O T E D$ is greater 
than its median value, and zero otherwise.

HZERO

Dummy variable takes value of one if ZERO is greater than its median value, and zero otherwise.

INSTWON The average of percentages of shares outstanding held by institutional investors over the four quarters of the firm's fiscal year.

INVVOL $\quad 1$ / annualized stock return volatility.

ITA The ratio of intangible assets to total assets.

LAMIHUD Dummy variable takes value of one if $A M I H U D$ is equal to or less than its median value, and zero otherwise.

LANALYSTS Dummy variable takes value of one if ANALYSTS is equal to or less than its median value, and zero otherwise.

LDEDOWN Dummy variable takes value of one if $D E D O W N$ is equal to or less than its median value, and zero otherwise.

LINSTOWN Dummy variable takes value of one if INSTOWN is equal to or less than its median value, and zero otherwise.

LEVERAGE Sum of the book value of short-term and long-term debt deflated by the book value of equity.

LNEQUITY Natural logarithm of total equity.

LNDEBT Natural logarithm of face value of debt.

LNTA Natural logarithm of total assets in year $\mathrm{t}-1$.

LOSS Dummy variable equal to one if net income is less than zero, and zero otherwise.

LPIN Dummy variable takes value of one if PIN is equal to or less 
than its median value, and zero otherwise.

LQUOTED

Dummy variable takes value of one if QUOTED is equal to

or less than its median value, and zero otherwise.

LZERO

Dummy variable takes value of one if ZERO is equal to or less than its median value, and zero otherwise.

$M E R G E R$

An indicator variable equal to one if there was merger

activity during the year (ACQ $>0$ or ACQCSHI $>0$ ), and 0

otherwise

$M T B$

[(Total assets - book value of common equity) + market

value of common equity] / total assets.

NI/TA

Ratio of net income to total assets.

$N O L$

An indicator variable equal to one if there was a tax loss

carryforward at the end of the year (TLCF $>0$ ), and 0

otherwise

PIN

Probability of insider trading, obtained from

http://scholar.rhsmith.umd.edu/sbrown/pin-data.

QUOTED Stock illiquidity, quoted spread, defined as the average of the daily quoted spread. The quoted spread for each day is computed as (Ask - Bid)/M, where Ask and Bid are the closing best offer and bid prices, respectively and $\mathrm{M}$ is the quote midpoint, computed as $(\mathrm{Ask}+\mathrm{Bid}) / 2$.

$R \& D E X P$ The ratio of research and development expense on total sales.

RAJGOPALSQ Square of firm residual, calculated using Equation 2 in 
Rajgopal and Venkatachalam (2011).

$T A$

Total assets in million.

WWROS

Consolidated pre-tax income / consolidated sales.

ZERO

Stock illiquidity, the percentage of zero daily returns

(Lesmond et al., 1999). 
APPENDIX 2 - APTS AND INCOME SHIFTING - PEARSON CORRELATION MATRIX

\begin{tabular}{|c|c|c|c|c|c|c|c|c|c|c|c|c|}
\hline & 1 & 2 & 3 & 4 & 5 & 6 & 7 & 8 & 9 & 10 & 11 & 12 \\
\hline \multicolumn{13}{|l|}{ 1. $\triangle \mathrm{PIFO}$} \\
\hline 2. $\triangle \mathrm{PIDOM}$ & $0.14^{*}$ & & & & & & & & & & & \\
\hline 3. $\triangle$ SALEFO & $0.33 *$ & $0.15 *$ & & & & & & & & & & \\
\hline 4. $\triangle$ SALEDOM & $0.11 *$ & $0.20 *$ & $0.27 *$ & & & & & & & & & \\
\hline 5.TAXFEES & 0.01 & -0.01 & 0.01 & -0.02 & & & & & & & & \\
\hline 6.ATS & 0.02 & $-0.02 *$ & 0.01 & 0.00 & $0.53 *$ & & & & & & & \\
\hline 7.WWROS & $0.23 *$ & $0.29 *$ & $0.16^{*}$ & $0.15 *$ & 0.00 & $0.16^{*}$ & & & & & & \\
\hline 8.R\&DEXP & -0.01 & $-0.02 *$ & $-0.04 *$ & $-0.06^{*}$ & 0.00 & $-0.08 *$ & $-0.21 *$ & & & & & \\
\hline 9.ADVEXP & -0.01 & $-0.03 *$ & -0.02 & 0.00 & $0.03 *$ & $0.05^{*}$ & $0.04^{*}$ & $-0.05^{*}$ & & & & \\
\hline 10.FTS & $0.06^{*}$ & $-0.03 *$ & $0.15^{*}$ & $-0.17^{*}$ & $0.06^{*}$ & $0.09 *$ & $0.05 *$ & $0.28^{*}$ & $-0.10 *$ & & & \\
\hline 11.CTA & $0.04 *$ & $0.05^{*}$ & -0.01 & $-0.04^{*}$ & -0.01 & $-0.13 *$ & $-0.06 *$ & $0.41^{*}$ & $0.02 *$ & $0.16^{*}$ & & \\
\hline 12.DTA & $-0.05^{*}$ & $-0.06^{*}$ & $-0.06^{*}$ & -0.02 & 0.02 & $0.15^{*}$ & $-0.06 *$ & $-0.24 *$ & $0.08^{*}$ & $-0.10^{*}$ & $-0.35^{*}$ & \\
\hline 13.LNTA & 0.01 & $-0.04 *$ & 0.00 & 0.01 & 0.08 & $0.48 *$ & $0.34 *$ & $-0.19 *$ & $0.11 *$ & $0.07 *$ & $-0.30 *$ & $0.30 *$ \\
\hline 14.ITA & $-0.02 *$ & $-0.04 *$ & -0.01 & $0.06^{*}$ & $0.06^{*}$ & $0.14 *$ & $0.08^{*}$ & 0.00 & $0.14^{*}$ & $-0.14^{*}$ & $-0.25^{*}$ & $0.23 *$ \\
\hline 15.MERGER & -0.01 & $-0.06 *$ & $0.07 *$ & $0.10^{*}$ & $0.03 *$ & $0.15^{*}$ & $0.12 *$ & $-0.05^{*}$ & -0.01 & $-0.04 *$ & $-0.14 *$ & $0.07 *$ \\
\hline 16.NOL & -0.01 & -0.02 & -0.01 & -0.01 & $-0.02 *$ & -0.01 & $-0.09 *$ & $0.06^{*}$ & -0.01 & $0.05 *$ & $0.03 *$ & $0.08 *$ \\
\hline 17.CAPINT & 0.02 & 0.00 & $0.04 *$ & $0.04 *$ & $-0.07 *$ & $0.03 *$ & $0.10^{*}$ & $-0.33 *$ & $-0.10 *$ & $-0.02 *$ & $-0.31 *$ & $0.27 *$ \\
\hline 18.INSTOWN & $0.03 *$ & 0.01 & -0.01 & -0.02 & $0.05^{*}$ & $0.17 *$ & $0.11 *$ & -0.02 & -0.02 & $0.04 *$ & $-0.03 *$ & $0.06 *$ \\
\hline 19.AUDINDEP & -0.01 & $-0.02 *$ & 0.00 & 0.01 & $0.12 *$ & $0.07 *$ & $0.02 *$ & $-0.02 *$ & $0.03^{*}$ & $-0.08 *$ & $-0.06^{*}$ & $0.07 *$ \\
\hline 20.AUDTENURE & -0.01 & $-0.03 *$ & $-0.05^{*}$ & $-0.02 *$ & $0.08^{*}$ & $0.21 *$ & $0.15^{*}$ & $-0.09 *$ & $0.04^{*}$ & $0.04 *$ & $-0.11 *$ & $0.06 *$ \\
\hline 21.LEVERAGE & $-0.09 *$ & $-0.09 *$ & $-0.08^{*}$ & $-0.10^{*}$ & -0.01 & 0.00 & $-0.26^{*}$ & $-0.19 *$ & 0.00 & $-0.07 *$ & $-0.25^{*}$ & $0.50 *$ \\
\hline 22.AUDFEES & -0.01 & $-0.06 *$ & -0.02 & -0.02 & $0.15^{*}$ & $0.48 *$ & $0.20 *$ & $-0.14 *$ & $0.10^{*}$ & $0.15^{*}$ & $-0.21 *$ & $0.26 *$ \\
\hline 23.AUDCHANGE & 0.00 & 0.00 & -0.02 & $-0.03^{*}$ & $-0.03 *$ & $-0.09 *$ & $-0.06 *$ & 0.00 & -0.02 & -0.01 & 0.00 & -0.02 \\
\hline \multicolumn{13}{|c|}{ * Indicates statistical significance at the 5 percent level. } \\
\hline
\end{tabular}


APPENDIX 2 - APTS AND INCOME SHIFTING - PEARSON CORRELATION MATRIX (CONTINUE)

\begin{tabular}{|c|c|c|c|c|c|c|c|c|c|c|}
\hline & 13 & 14 & 15 & 16 & 17 & 18 & 19 & 20 & 21 & 22 \\
\hline 14.ITA & $0.22 *$ & & & & & & & & & \\
\hline 15.MERGE & $0.26^{*}$ & $0.33^{*}$ & & & & & & & & \\
\hline 16.NOL & 0.01 & $0.08 *$ & 0.01 & & & & & & & \\
\hline 17.CAPINT & $0.22 *$ & $-0.35^{*}$ & $-0.08 *$ & $-0.05 *$ & & & & & & \\
\hline 18.INSTOWN & $0.26^{*}$ & $0.08 *$ & $0.10 *$ & 0.00 & $0.02 *$ & & & & & \\
\hline 19.AUDINDEP & $0.11 *$ & $0.07 *$ & $0.10 *$ & $-0.04 *$ & 0.01 & 0.00 & & & & \\
\hline 20.AUDTENURE & $0.35 *$ & $0.05^{*}$ & $0.08 *$ & $-0.02 *$ & $0.04 *$ & $0.12 *$ & 0.00 & & & \\
\hline 21.LEVERAGE & $0.05^{*}$ & 0.00 & $-0.06^{*}$ & $0.05^{*}$ & $0.18^{*}$ & $-0.09 *$ & $0.03 *$ & $-0.04 *$ & & \\
\hline 22.AUDFEES & $0.87 *$ & $0.23 *$ & $0.25^{*}$ & $0.05^{*}$ & $0.07 *$ & $0.23 *$ & 0.00 & $0.32 *$ & $0.05 *$ & \\
\hline 23.AUDCHANGE & $-0.13^{*}$ & $-0.04 *$ & $-0.05 *$ & 0.00 & -0.01 & $-0.08 *$ & 0.01 & $-0.26^{*}$ & $0.04 *$ & $-0.12 *$ \\
\hline
\end{tabular}




\section{APPENDIX 3 - APTS AND DEFAULT RISK - PEARSON CORRELATION MATRIX}

\begin{tabular}{|c|c|c|c|c|c|c|c|c|c|c|c|c|c|c|c|c|c|c|c|}
\hline & 1 & 2 & 3 & 4 & 5 & 6 & 7 & 8 & 9 & 10 & 11 & 12 & 13 & 14 & 15 & 16 & 17 & 18 & 19 \\
\hline 1.DEFAULT1 & & & & & & & & & & & & & & & & & & & \\
\hline 2.TAXFEES & $-0.02^{*}$ & & & & & & & & & & & & & & & & & & \\
\hline 3.ATS & $-0.12^{*}$ & $0.52 *$ & & & & & & & & & & & & & & & & & \\
\hline 4.DEFAULT2 & $0.97 *$ & $-0.03 *$ & $-0.09 *$ & & & & & & & & & & & & & & & & \\
\hline 5.EDF & $0.27 *$ & $-0.02 *$ & $-0.05^{*}$ & $0.25^{*}$ & & & & & & & & & & & & & & & \\
\hline 6.RAJGOPALSQ & $0.24 *$ & $0.02 *$ & $-0.12 *$ & $0.20 *$ & $0.11 *$ & & & & & & & & & & & & & & \\
\hline 7.INSTOWN & $-0.18^{*}$ & $0.07 *$ & $0.24 *$ & $-0.15^{*}$ & $-0.10^{*}$ & $-0.15^{*}$ & & & & & & & & & & & & & \\
\hline 8.DEDOWN & 0.00 & $0.03^{*}$ & $0.07 *$ & 0.01 & -0.01 & $-0.05^{*}$ & $0.40^{*}$ & & & & & & & & & & & & \\
\hline 9.ANALYSTS & $-0.16^{*}$ & $0.04 *$ & $0.29 *$ & $-0.13^{*}$ & $-0.08^{*}$ & $-0.14 *$ & $0.30^{*}$ & $0.08 *$ & & & & & & & & & & & \\
\hline 11.LNEQUITY & $-0.28^{*}$ & $0.10^{*}$ & $0.45^{*}$ & $-0.24 *$ & $-0.25^{*}$ & $-0.23 *$ & $0.42 *$ & $0.13^{*}$ & $0.68 *$ & $-0.77 *$ & & & & & & & & & \\
\hline 12.LNDEBT & -0.01 & $0.06^{*}$ & $0.41 *$ & $0.04 *$ & $0.05^{*}$ & $-0.19 *$ & $0.33 *$ & $0.13 *$ & $0.52 *$ & $-0.55^{*}$ & $0.74 *$ & & & & & & & & \\
\hline 13.NI/TA & $-0.55^{*}$ & $0.02 *$ & $0.21 *$ & $-0.53^{*}$ & $-0.23 *$ & $-0.27 *$ & $0.20 *$ & $0.02 *$ & $0.18^{*}$ & $-0.21 *$ & $0.38^{*}$ & $0.27 *$ & & & & & & & \\
\hline 14.INVVOL & $-0.19^{*}$ & $0.01 *$ & $0.19 *$ & $-0.17 *$ & $-0.23 *$ & $-0.16^{*}$ & $0.10^{*}$ & $0.03 *$ & $0.22 *$ & $-0.21 *$ & $0.49 *$ & $0.39 *$ & $0.32 *$ & & & & & & \\
\hline 15.EXRET & $-0.18^{*}$ & 0.00 & 0.00 & $-0.19 *$ & $-0.29 *$ & $-0.03 *$ & 0.01 & -0.01 & $-0.04 *$ & 0.00 & $0.10^{*}$ & $-0.03 *$ & $0.19^{*}$ & $-0.08^{*}$ & & & & & \\
\hline 16.MTB & $-0.10^{*}$ & $0.04^{*}$ & $-0.04 *$ & $-0.14 *$ & $-0.14 *$ & $0.11 *$ & $-0.03^{*}$ & -0.01 & $0.12 *$ & $-0.15^{*}$ & $0.19 *$ & $-0.17 *$ & $-0.19^{*}$ & 0.00 & $0.24 *$ & & & & \\
\hline 17.QUOTED & $0.24 *$ & $-0.03^{*}$ & $-0.30^{*}$ & $0.19 *$ & $0.20 *$ & $0.21 *$ & $-0.41 *$ & $-0.11 *$ & $-0.38 *$ & $0.70^{*}$ & $-0.66^{*}$ & $-0.44 *$ & $-0.29 *$ & $-0.30^{*}$ & 0.00 & $-0.12 *$ & & & \\
\hline 18.AMIHUD & $0.16^{*}$ & $-0.02 *$ & $-0.19 *$ & $0.12 *$ & $0.14 *$ & $0.15^{*}$ & $-0.26^{*}$ & $-0.08^{*}$ & $-0.21 *$ & $0.45^{*}$ & $-0.41 *$ & $-0.25^{*}$ & $-0.16^{*}$ & $-0.17 *$ & 0.00 & $-0.10 *$ & $0.81 *$ & & \\
\hline 19.ZERO & $0.30^{*}$ & $-0.05^{*}$ & $-0.32 *$ & $0.25^{*}$ & $0.15^{*}$ & $0.21 *$ & $-0.42 *$ & $-0.10^{*}$ & $-0.43 *$ & $0.71 *$ & $-0.67 *$ & $-0.46^{*}$ & $-0.32 *$ & $-0.24 *$ & $-0.02 *$ & $-0.09 *$ & $0.71 *$ & $0.50 *$ & \\
\hline 20.LOSS & $0.37 *$ & $-0.02 *$ & $-0.18 *$ & $0.36^{*}$ & $0.29 *$ & $0.18^{*}$ & $-0.17 *$ & 0.00 & $-0.18^{*}$ & $0.26^{*}$ & $-0.40 *$ & $-0.25^{*}$ & $-0.63 *$ & $-0.39^{*}$ & $-0.17 *$ & $0.03 *$ & $0.30^{*}$ & $0.18 *$ & $0.33^{*}$ \\
\hline 22.NOL & $0.09 *$ & $0.05^{*}$ & $0.03 *$ & $0.10^{*}$ & $0.03 *$ & $0.03 *$ & $0.03 *$ & $0.02 *$ & $0.03 *$ & $-0.02^{*}$ & 0.00 & -0.01 & $-0.11 *$ & $-0.11^{*}$ & $-0.04 *$ & $0.04 *$ & $-0.03 *$ & -0.01 & 0.00 \\
\hline 23.CAPINT & $0.02 *$ & $-0.19 *$ & $-0.07 *$ & $0.04 *$ & $0.05^{*}$ & $-0.08 *$ & $-0.02 *$ & -0.01 & $0.09 *$ & $-0.05^{*}$ & $0.09 *$ & $0.24 *$ & $0.15^{*}$ & $0.11 *$ & $0.03^{*}$ & $-0.16^{*}$ & $-0.06 *$ & $-0.04 *$ & $-0.09 *$ \\
\hline 24.AUDINDEP & 0.01 & 0.088 & $0.06^{*}$ & 0.01 & 0.00 & 0.01 & $-0.03 *$ & -0.01 & $0.02 *$ & 0.00 & $0.04 *$ & $0.05^{*}$ & 0.00 & 0.00 & $0.03 *$ & 0.00 & $0.04 *$ & 0.00 & 0.01 \\
\hline 25.AUDTENURE & $-0.11^{*}$ & $0.09 *$ & $0.20 *$ & $-0.10^{*}$ & $-0.08^{*}$ & $-0.08 *$ & $0.16^{*}$ & 0.00 & $0.21 *$ & $-0.23^{*}$ & $0.33^{*}$ & $0.27 *$ & $0.17 *$ & $0.25 *$ & $-0.02 *$ & $-0.03 *$ & $-0.20 *$ & $-0.10^{*}$ & $-0.22 *$ \\
\hline 26.LEVERAGE & $0.22 *$ & $-0.03^{*}$ & 0.00 & $0.22 *$ & $0.65^{*}$ & $0.03 *$ & $-0.05^{*}$ & $0.03 *$ & $-0.09 *$ & $0.14^{*}$ & $-0.21 *$ & $0.25^{*}$ & $-0.12 *$ & $-0.17 *$ & $-0.17 *$ & $-0.25^{*}$ & $0.19 *$ & $0.13^{*}$ & $0.16^{*}$ \\
\hline 27.AUDFEES & $-0.09^{*}$ & $0.19 *$ & 0.508 & $-0.06^{*}$ & $-0.06^{*}$ & $-0.19 *$ & $0.40 *$ & $0.14 *$ & $0.53 *$ & $-0.65^{*}$ & $0.81 *$ & $0.75^{*}$ & $0.27 *$ & $0.37 *$ & $-0.04 *$ & $-0.06^{*}$ & $-0.56^{*}$ & $-0.34 *$ & $-0.55^{*}$ \\
\hline 28.AUDCHANGE & $0.04 *$ & $-0.02 *$ & $-0.08 *$ & $0.03 *$ & $0.04 *$ & $0.05 *$ & $-0.11 *$ & $-0.02 *$ & $-0.09 *$ & $0.13^{*}$ & $-0.14 *$ & $-0.09 *$ & $-0.07 *$ & $-0.09^{*}$ & 0.00 & $-0.02 *$ & $0.13 *$ & $0.06^{*}$ & $0.11 *$ \\
\hline 29.LNTA & $-0.18^{*}$ & $0.08 *$ & $0.48 *$ & $-0.13 *$ & $-0.07 *$ & $-0.25^{*}$ & $0.42 *$ & $0.14^{*}$ & $0.63^{*}$ & $-0.71 *$ & $0.91 *$ & $0.88 *$ & $0.39 *$ & $0.46^{*}$ & -0.01 & $-0.13 *$ & $-0.59 *$ & $-0.36^{*}$ & $-0.61 *$ \\
\hline 30.GROWTH & $-0.14 *$ & $-0.04 *$ & -0.01 & $-0.13 *$ & $-0.11 *$ & $-0.03 *$ & $-0.02 *$ & $-0.04 *$ & $0.03 *$ & $-0.09 *$ & $0.10^{*}$ & 0.00 & $0.20 *$ & -0.01 & $0.19^{*}$ & $0.16^{*}$ & $-0.12 *$ & $-0.09 *$ & $-0.11 *$ \\
\hline
\end{tabular}


APPENDIX 3 - APTS AND DEFAULT RISK - PEARSON CORRELATION MATRIX (CONTINUE)

\begin{tabular}{|c|c|c|c|c|c|c|c|c|c|c|}
\hline & 20 & 21 & 22 & 23 & 24 & 25 & 26 & 27 & 28 & 29 \\
\hline 21.MERGER & $-0.18^{*}$ & & & & & & & & & \\
\hline 22.NOL & $0.13^{*}$ & $0.06^{*}$ & & & & & & & & \\
\hline 23.CAPINT & $-0.11 *$ & $-0.13 *$ & $-0.16^{*}$ & & & & & & & \\
\hline 24.AUDINDEP & 0.00 & $0.06 *$ & $-0.05^{*}$ & 0.01 & & & & & & \\
\hline 25.AUDTENURE & $-0.17 *$ & $0.08^{*}$ & $-0.02 *$ & -0.01 & $-0.03 *$ & & & & & \\
\hline 26.LEVERAGE & $0.24 *$ & $-0.07 *$ & 0.01 & $0.16^{*}$ & $0.02 *$ & $-0.07 *$ & & & & \\
\hline 27.AUDFEES & $-0.24 *$ & $0.29 *$ & $0.10^{*}$ & $-0.03 *$ & $-0.09 *$ & $0.32 *$ & $0.03^{*}$ & & & \\
\hline 28.AUDCHANGE & $0.06^{*}$ & $-0.03 *$ & -0.01 & 0.00 & $0.03^{*}$ & $-0.28 *$ & $0.05^{*}$ & $-0.13^{*}$ & & \\
\hline 29.LNTA & $-0.35^{*}$ & $0.25 *$ & -0.01 & $0.18 *$ & $0.04 *$ & $0.33^{*}$ & $0.08^{*}$ & $0.87^{*}$ & $-0.13^{*}$ & \\
\hline 30.GROWTH & $-0.15^{*}$ & $0.17 *$ & 0.00 & $0.18 *$ & $0.10^{*}$ & $-0.07 *$ & $-0.11 *$ & $-0.02 *$ & 0.00 & $0.02 *$ \\
\hline
\end{tabular}




\section{APPENDIX 4 - SUMMARY OF KEY EMPIRICAL STUDIES CITED}

\begin{tabular}{|c|c|c|c|c|}
\hline $\mathbf{S} / \mathbf{N}$ & CITATION & OBJECTIVE & $\begin{array}{c}\text { METHODS, DATA, AND } \\
\text { SAMPLE }\end{array}$ & FINDINGS \\
\hline 1 & $\begin{array}{l}\text { Abbott, L. J., Parker, } \\
\text { S., Peters, G. F., \& } \\
\text { Raghunandan, K. } \\
\text { (2003). An Empirical } \\
\text { Investigation of Audit } \\
\text { Fees, Nonaudit Fees, } \\
\text { and Audit Committees. } \\
\text { Contemporary } \\
\text { Accounting Research, } \\
\text { 20, 215-234. }\end{array}$ & $\begin{array}{l}\text { The authors examine } \\
\text { whether audit committee } \\
\text { characteristics influence } \\
\text { the ratio of non-audit } \\
\text { services fees to audit fees. }\end{array}$ & $\begin{array}{l}\text { The authors use regression } \\
\text { analysis to link the test } \\
\text { variables and controls. } \\
\text { The initial sample is based on } \\
\text { all proxy statements } \\
\text { (excluding mutual funds and } \\
\text { other financial registrants) } \\
\text { filed with the SEC between } \\
\text { 5th February } 2001 \text { - 16th } \\
\text { March } 2001 \text {. The authors } \\
\text { ensure that the proxy } \\
\text { statements have a } \\
\text { corresponding } 10 \mathrm{~K} \text { filing } \\
\text { available by } 16 \text { th March } 2001 \text {. } \\
\text { They also include a sample of }\end{array}$ & $\begin{array}{l}\text { The authors argue that independent audit } \\
\text { committees and those that actively monitor } \\
\text { firms' financial aspects have higher } \\
\text { motivation to limit non-audit services fees } \\
\text { to enhance auditor independence or to } \\
\text { manage litigation-related concerns about } \\
\text { auditor independence. } \\
\text { The authors find that the independence and } \\
\text { meeting frequency of audit committees are } \\
\text { negatively related to the ratio of non-audit } \\
\text { fees to audit fees. Specifically, they find } \\
\text { that firms with audit committees that } \\
\text { consist of all independent directors and } \\
\text { meet at least four times per year have a } \\
\text { lower ratio of non-audit fees to audit fees. }\end{array}$ \\
\hline
\end{tabular}




\begin{tabular}{|c|c|c|c|c|}
\hline & & & $\begin{array}{l}250 \text { randomly selected proxy } \\
\text { filings from 19th March } 2001 \\
\text { to } 30 \text { th June } 2001 \text {. The final } \\
\text { sample consists of } 538 \text { U.S. } \\
\text { firms. }\end{array}$ & $\begin{array}{l}\text { The result is robust even after the authors } \\
\text { exclude information technology fees from } \\
\text { non-audit fees and include it as a control } \\
\text { variable. The result is also robust to } \\
\text { including board characteristics and } \\
\text { profitability. The result also holds when } \\
\text { the authors consider Big5 audit firms, } \\
\text { client complexity, audit opinion, and } \\
\text { regulated industries. }\end{array}$ \\
\hline 2 & $\begin{array}{l}\text { Antle, R., Gordon, E., } \\
\text { Narayanamoorthy, G., } \\
\text { \& Zhou, L. (2006). The } \\
\text { joint determination of } \\
\text { audit fees, non-audit } \\
\text { fees, and abnormal } \\
\text { accruals. Review of } \\
\text { Quantitative Finance } \\
\text { and Accounting, 27, } \\
\text { 235-266. }\end{array}$ & $\begin{array}{l}\text { The authors investigate the } \\
\text { relationship among audit } \\
\text { fees, non-audit fees, and } \\
\text { abnormal accruals as } \\
\text { endogenous variables in a } \\
\text { three simultaneous } \\
\text { equation model. }\end{array}$ & $\begin{array}{l}\text { The authors use regression } \\
\text { analysis to link the test } \\
\text { variables and controls. The } \\
\text { test develops an empirical } \\
\text { model based on United } \\
\text { Kingdom data and United } \\
\text { States data is used as } \\
\text { comparison. } \\
\text { Data on auditor fees in the }\end{array}$ & $\begin{array}{l}\text { The authors argue that previous studies fail } \\
\text { to consider that audit fees, non-audit fees, } \\
\text { and abnormal accruals are jointly } \\
\text { determined and the variables are related to } \\
\text { each other. They find a positive and } \\
\text { significant effect of audit fees on abnormal } \\
\text { accruals in both the United States and } \\
\text { United Kingdom. They argue that this is } \\
\text { consistent with the unconscious influence } \\
\text { of bias theory in the behavioural literature. }\end{array}$ \\
\hline
\end{tabular}




\begin{tabular}{|c|c|c|c|c|}
\hline & & & $\begin{array}{l}\text { United Kingdom is gathered } \\
\text { from the Financial Times, } \\
\text { while other required data is } \\
\text { obtained from the Global } \\
\text { Vantage database. For United } \\
\text { States data, they gather the } \\
\text { auditor fees data from the } \\
\text { Investor Responsibility } \\
\text { Resource Center (IRRC) and } \\
\text { other required data is } \\
\text { gathered from the Compustat } \\
\text { database. The final sample } \\
\text { consists of } 2,294 \text { firm-year } \\
\text { observations on United } \\
\text { Kingdom data during } 1994 \text { - } \\
2000 \text { period and } 1,570 \text { United } \\
\text { States firms for the fiscal year } \\
2000 \text {. }\end{array}$ & $\begin{array}{l}\text { However, they fail to find that abnormal } \\
\text { accruals significantly affect audit fees. } \\
\text { Furthermore, they find a negative effect of } \\
\text { non-audit fees on abnormal accruals in the } \\
\text { United Kingdom consistent with } \\
\text { productive effect of non-audit services. } \\
\text { They also find evidence consistent with a } \\
\text { knowledge spillovers effect from auditing } \\
\text { to non-audit services and from non-audit } \\
\text { services to auditing. }\end{array}$ \\
\hline 3 & Bennett, R. L., Güntay, & The authors investigate the & The authors use regression & The authors argue that CEOs who \\
\hline
\end{tabular}




\begin{tabular}{|c|c|c|c|}
\hline $\begin{array}{l}\text { L., \& Unal, H. (2015). } \\
\text { Inside debt, bank } \\
\text { default risk, and } \\
\text { performance during the } \\
\text { crisis. Journal of } \\
\text { Financial } \\
\text { Intermediation, 24, } \\
487-513 \text {. }\end{array}$ & $\begin{array}{l}\text { relationship between CEO } \\
\text { inside debt holdings, } \\
\text { default risk, and } \\
\text { performance during the } \\
\text { global financial crisis. } \\
\text { The authors examine the } \\
\text { relationship between risk- } \\
\text { taking and CEO inside } \\
\text { equity holdings including } \\
\text { options. In addition, they } \\
\text { examine whether CEO } \\
\text { inside debt holdings } \\
\text { (pension benefits and } \\
\text { deferred compensation) } \\
\text { influences the default risk } \\
\text { and performance of bank } \\
\text { holding companies. They } \\
\text { also compare the power of }\end{array}$ & $\begin{array}{l}\text { analysis to link the test } \\
\text { variables and controls. } \\
\text { The sample consists of U.S. } \\
\text { financial institutions that filed } \\
\text { a regulatory report in } \\
\text { 2006Q4. Data on these } \\
\text { institutions are obtained from } \\
\text { the Y9C filings and bank- } \\
\text { level Call Reports. The CEO } \\
\text { compensation information is } \\
\text { obtained from the Compustat } \\
\text { Execucomp database and } \\
\text { DEF14A filings from the } \\
\text { SEC EDGAR database. The } \\
\text { authors remove bank holding } \\
\text { companies with assets in } \\
\text { insured U.S. depository } \\
\text { institutions less than } 20 \% \text { of }\end{array}$ & $\begin{array}{l}\text { maximize shareholders interest might } \\
\text { engage in activities that are unfavorable for } \\
\text { other stakeholders such as debt holders and } \\
\text { deposit insurers. However, the interest of } \\
\text { those other stakeholders might potentially } \\
\text { be insured if CEOs are compensated using } \\
\text { inside debt. This happens as CEOs are then } \\
\text { bound to be more concerned about the } \\
\text { firms' long-term solvency and thus engage } \\
\text { in favorable investments for those other } \\
\text { stakeholders. Hence, they argue that firms } \\
\text { with higher inside debt compensation for } \\
\text { their CEO are less likely to default and } \\
\text { perform better during the financial crisis } \\
\text { period. } \\
\text { The authors find that firms with higher } \\
\text { CEO inside debt relative to inside equity } \\
\text { have lower default risk and better }\end{array}$ \\
\hline
\end{tabular}




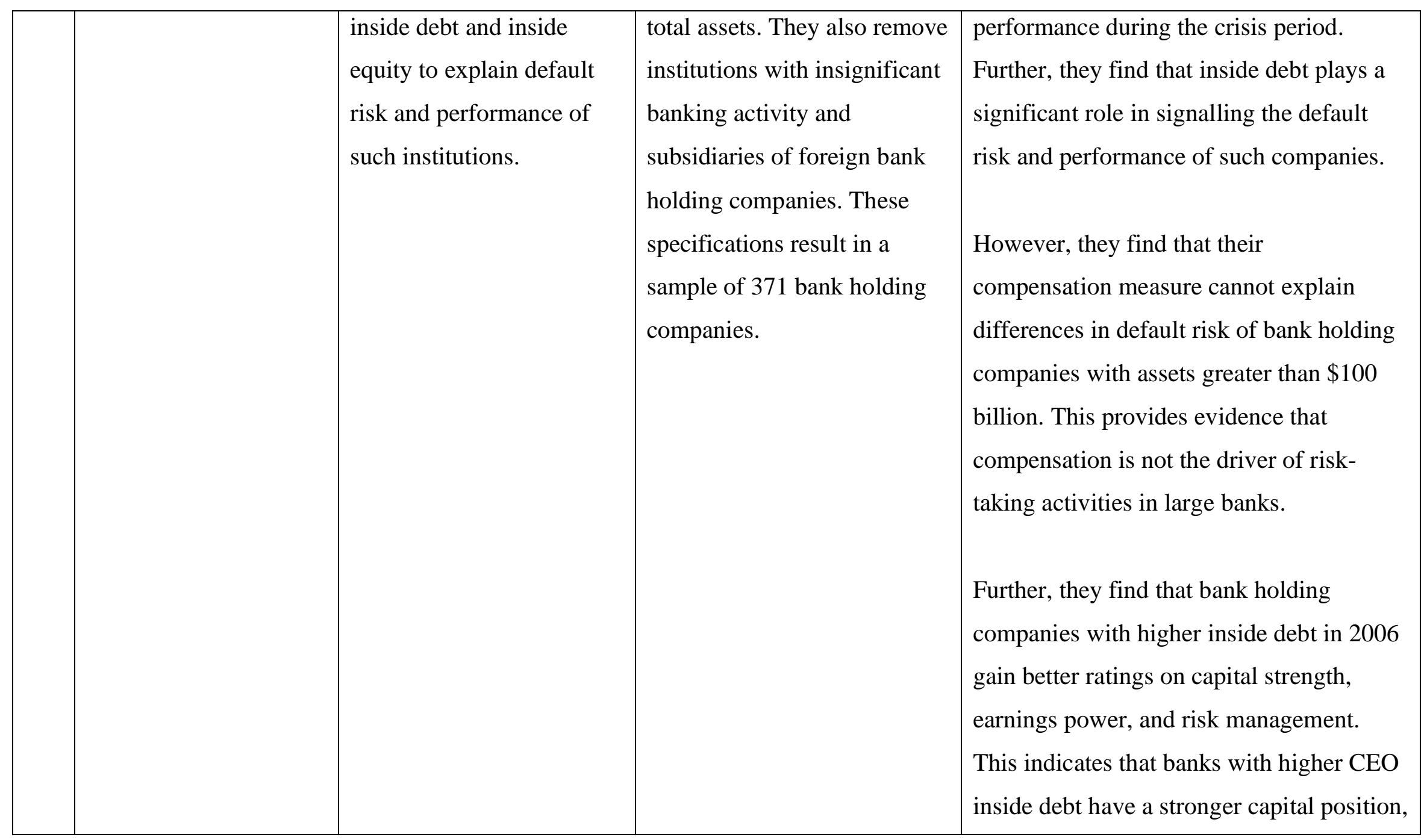




\begin{tabular}{|c|c|c|c|c|}
\hline & & & & $\begin{array}{l}\text { better management, stronger earnings, and } \\
\text { are in a better position to face market } \\
\text { shocks. }\end{array}$ \\
\hline 4 & $\begin{array}{l}\text { Brogaard, J., Li, D., \& } \\
\text { Xia, Y. (2017). Stock } \\
\text { liquidity and default } \\
\text { risk. Journal of } \\
\text { Financial Economics, } \\
\text { 124, 486-502. }\end{array}$ & $\begin{array}{l}\text { The authors examine the } \\
\text { influence of stock liquidity } \\
\text { on default risk. }\end{array}$ & $\begin{array}{l}\text { The authors use regression } \\
\text { analysis to link the test } \\
\text { variables and controls. } \\
\text { The sample of the study } \\
\text { consists of U.S. firms during } \\
\text { the period } 1994 \text {-2014. The } \\
\text { authors gather the accounting } \\
\text { data from the Compustat and } \\
\text { prices from the CRSP } \\
\text { database. They also use the } \\
\text { Trade and Quoted database to } \\
\text { obtain intraday trades and } \\
\text { quotes. They exclude } \\
\text { financial firms and exclude } \\
\text { firm-year observations on }\end{array}$ & $\begin{array}{l}\text { The authors argue that liquidity can lead to } \\
\text { higher default risk if it increases noise } \\
\text { trading, thereby causing higher mispricing } \\
\text { and stock volatility. However, liquidity } \\
\text { may also reduce default risk if it enhances } \\
\text { price efficiency or improves governance } \\
\text { by blockholders through greater ease of } \\
\text { investors to exit. } \\
\text { They find a negative association between } \\
\text { liquidity and default risk. They estimate } \\
\text { that a one standard deviation increase in } \\
\text { liquidity is associated with a } 26.89 \% \\
\text { reduction in default risk over their sample } \\
\text { mean. }\end{array}$ \\
\hline
\end{tabular}




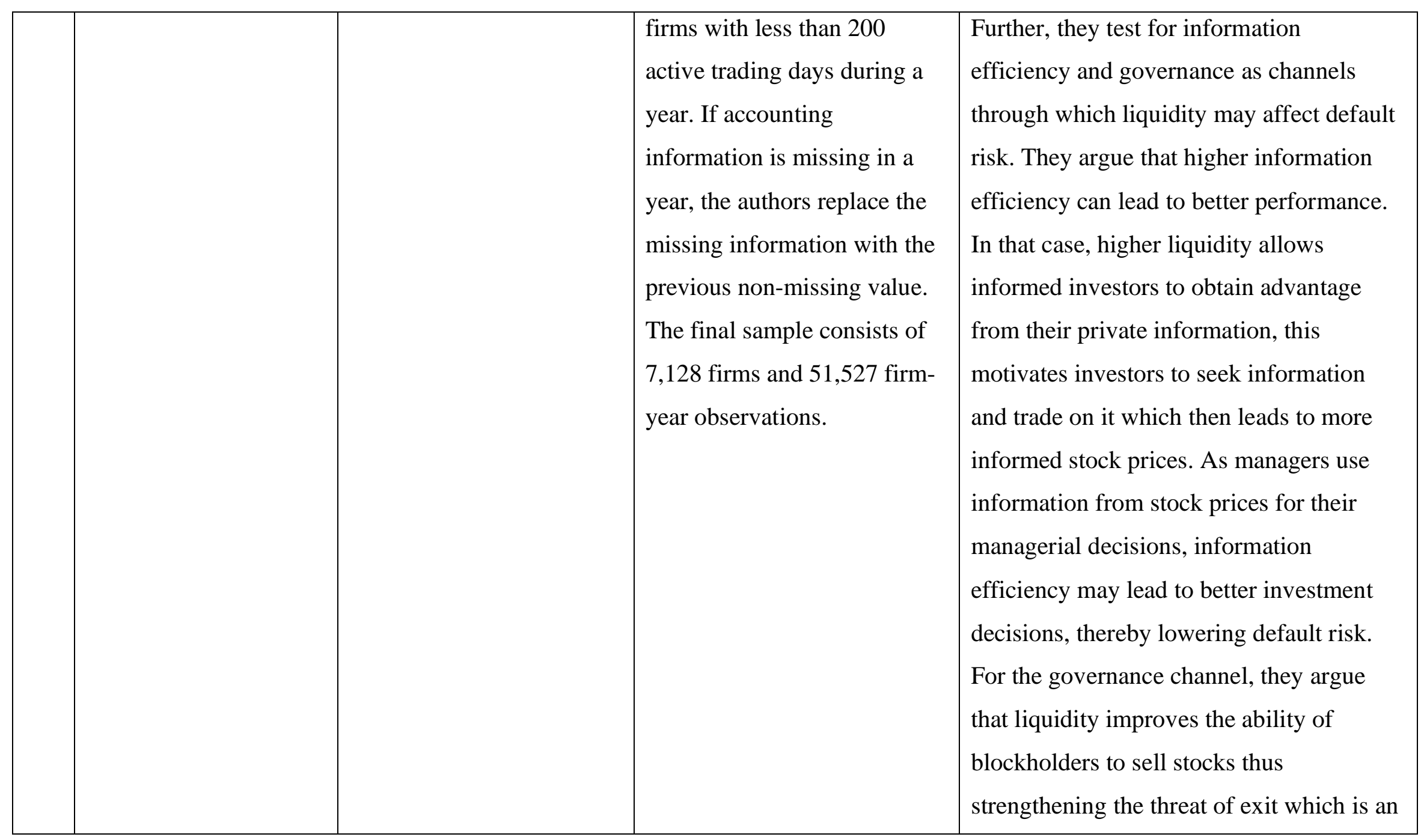




\begin{tabular}{|c|c|c|c|c|}
\hline & & & & $\begin{array}{l}\text { important governance mechanism. } \\
\text { Consequently, it limits managers } \\
\text { opportunistic behaviour and makes } \\
\text { managers engage in value-enhancing } \\
\text { investments, thereby lowering default risk. } \\
\text { As expected, the authors find that liquidity } \\
\text { improves default risk by enhancing } \\
\text { information efficiency and governance. } \\
\text { Furthermore, they find that information } \\
\text { efficiency has higher explanatory power on } \\
\text { reduction of default risk than does the } \\
\text { corporate governance channel. }\end{array}$ \\
\hline 5 & $\begin{array}{l}\text { Clausing, K. A. (2009). } \\
\text { Multinational Firm Tax } \\
\text { Avoidance and Tax } \\
\text { Policy. National Tax } \\
\text { Journal, 62, 703-725. }\end{array}$ & $\begin{array}{l}\text { Clausing (2009) examines } \\
\text { the relationship between } \\
\text { the profit rates of U.S. } \\
\text { affiliates and foreign } \\
\text { country tax rates and also } \\
\text { the influence of income } \\
\text { taxes on U.S. }\end{array}$ & $\begin{array}{l}\text { The author develops a } \\
\text { mathematical model to } \\
\text { explain the concept of } \\
\text { corporate tax revenue and } \\
\text { uses regression analysis to } \\
\text { link the test variables and } \\
\text { controls. }\end{array}$ & $\begin{array}{l}\text { Clausing (2009) argues that multinationals } \\
\text { have both financial and real responses to } \\
\text { taxation of corporate income. Financial } \\
\text { responses may include activities such as } \\
\text { shifting income to jurisdictions with lower } \\
\text { taxes. Real responses may include locating } \\
\text { more assets, employment, and economic }\end{array}$ \\
\hline
\end{tabular}




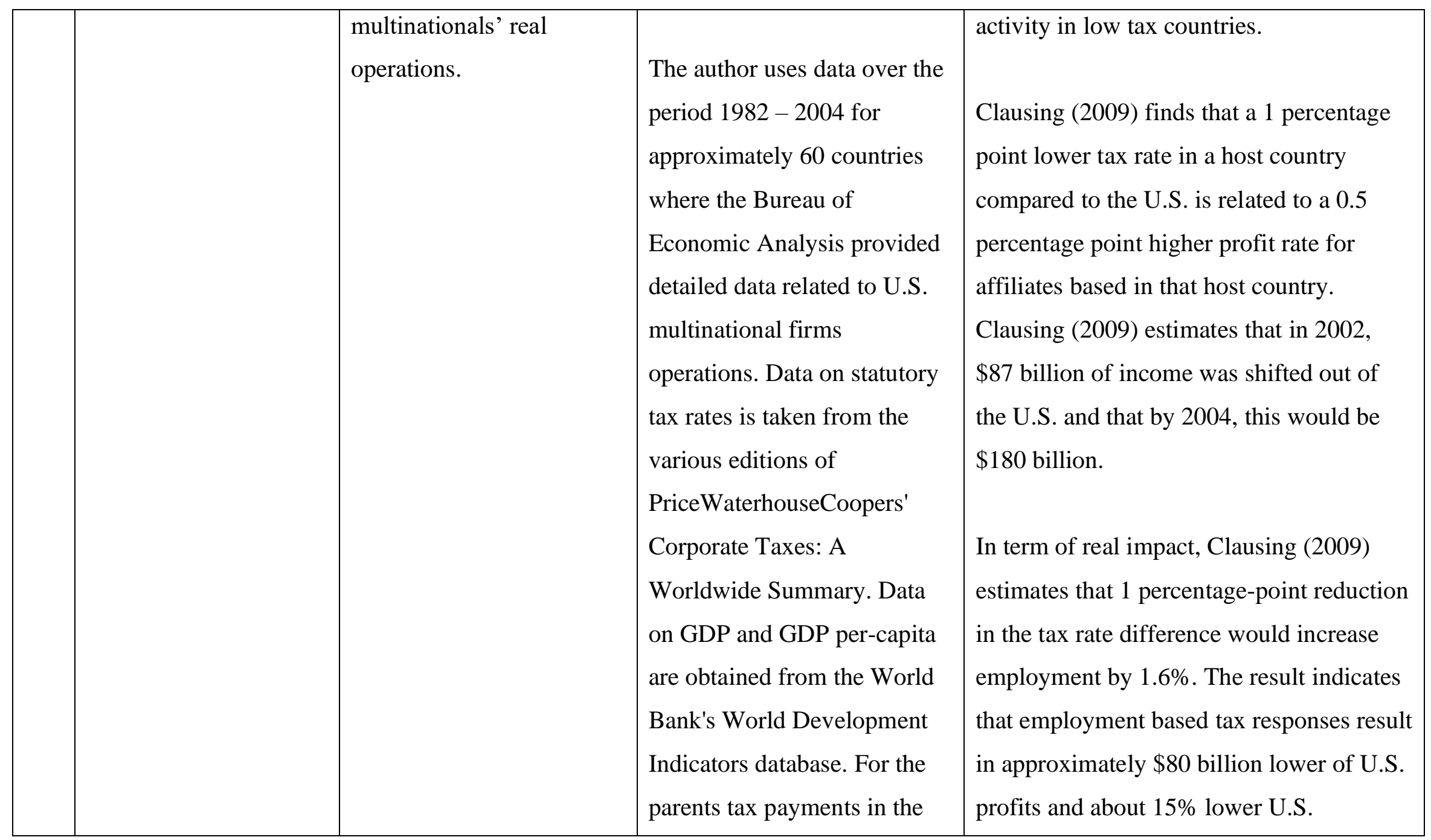




\begin{tabular}{|c|c|c|c|c|}
\hline & & & $\begin{array}{l}\text { U.S., the author relies on the } \\
\text { effective tax rates data in } \\
\text { Devereux and Griffith (2003). }\end{array}$ & government corporate tax revenues. \\
\hline 6 & $\begin{array}{l}\text { Collins, J., Kemsley, } \\
\text { D., \& Lang, M. (1998). } \\
\text { Cross-Jurisdictional } \\
\text { Income Shifting and } \\
\text { Earnings Valuation. } \\
\text { Journal of Accounting } \\
\text { Research, 36, 209-229 }\end{array}$ & $\begin{array}{l}\text { The authors investigate } \\
\text { two issues. First, they } \\
\text { examine the extent of } \\
\text { income shifting by U.S. } \\
\text { multinationals. Second, } \\
\text { they test how investors } \\
\text { value shifted income. } \\
\text { Specifically, whether } \\
\text { investors differentially } \\
\text { value shifted income based } \\
\text { on its true sources or its } \\
\text { reported sources. }\end{array}$ & $\begin{array}{l}\text { The authors use regression } \\
\text { analysis to link the test } \\
\text { variables and controls. } \\
\text { The authors test the issue } \\
\text { using all U.S. manufacturing } \\
\text { firms (SIC } 2000 \text { - 3999) } \\
\text { available in the the } \\
\text { Compustat database during } \\
\text { the period } 1984 \text { - 1992. The } \\
\text { authors exclude observations } \\
\text { with negative pre-tax } \\
\text { domestic and foreign income } \\
\text { or where the average foreign } \\
\text { tax rate less the U.S. statutory } \\
\text { tax rate is less than -1 or }\end{array}$ & $\begin{array}{l}\text { The U.S. taxes all income of U.S. } \\
\text { companies irrespective of the income } \\
\text { source but foreign-sourced income is taxed } \\
\text { only on repatriation to the U.S at the U.S. } \\
\text { rate and is subject to a credit for foreign } \\
\text { taxes paid. However, it means that U.S. } \\
\text { multinationals that have higher foreign tax } \\
\text { rates compared to the U.S. rate will not } \\
\text { receive a full U.S. credit for their foreign } \\
\text { tax payments. Consequently, such firms } \\
\text { have an incentive to shift pre-taxed foreign } \\
\text { income to the United States. } \\
\text { On the other hand, U.S. multinationals } \\
\text { with U.S. rate in excess of their average } \\
\text { foreign tax rate will face nonbinding }\end{array}$ \\
\hline
\end{tabular}




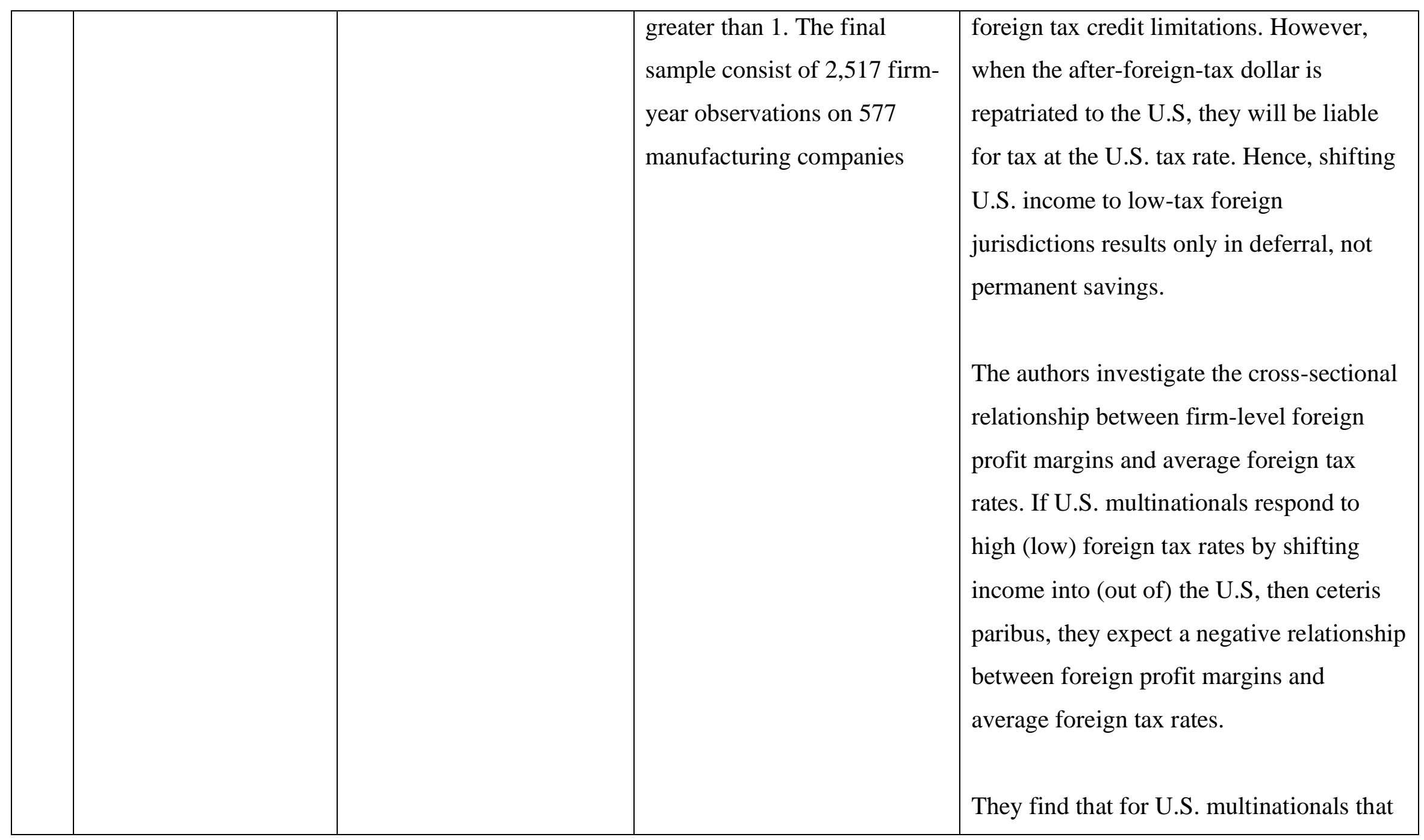




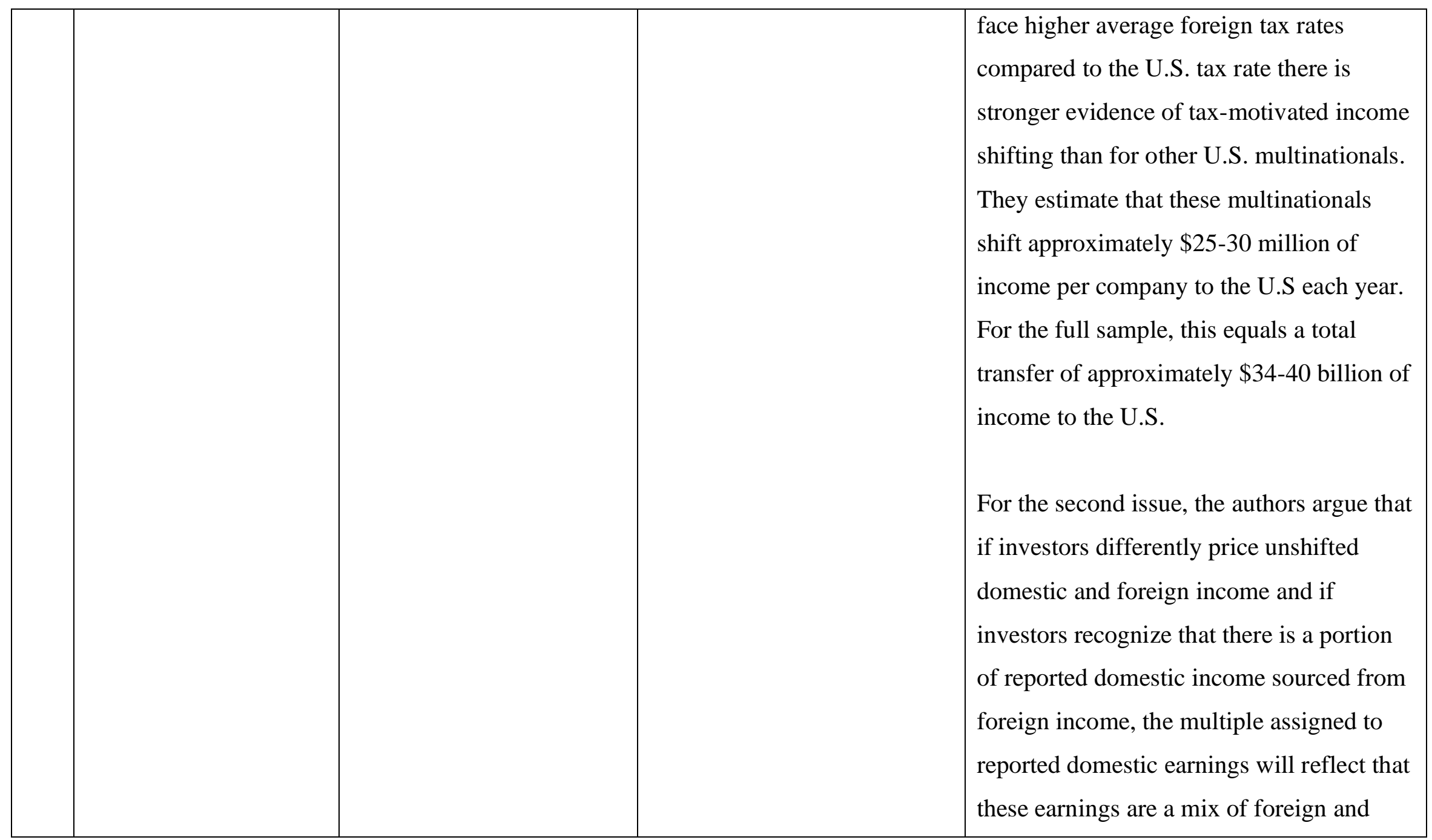




\begin{tabular}{|c|c|c|c|c|}
\hline & & & & $\begin{array}{l}\text { domestic source income. As per their } \\
\text { expectation, they find that investors } \\
\text { recognize the effects of income shifting in } \\
\text { their valuations. }\end{array}$ \\
\hline 7 & $\begin{array}{l}\text { Cook, K. A., Huston, } \\
\text { G. R., \& Omer, T. C. } \\
\text { (2008). Earnings } \\
\text { Management through } \\
\text { Effective Tax Rates: } \\
\text { The Effects of Tax- } \\
\text { Planning Investment } \\
\text { and the Sarbanes-Oxley } \\
\text { Act of } 2002 . \\
\text { Contemporary } \\
\text { Accounting Research, } \\
25(2), 447-471 .\end{array}$ & $\begin{array}{l}\text { The authors investigate } \\
\text { three issues. First, they } \\
\text { examine the extent to } \\
\text { which greater third-to- } \\
\text { fourth-quarter ETR } \\
\text { reductions are associated } \\
\text { with higher tax fees paid } \\
\text { to auditors for firms that } \\
\text { would miss their } \\
\text { consensus earnings } \\
\text { forecasts absent ETR } \\
\text { changes. Second, they } \\
\text { investigate the relationship } \\
\text { of firms' choices to } \\
\text { purchase tax services from }\end{array}$ & $\begin{array}{l}\text { The authors use regression } \\
\text { analysis to link the test } \\
\text { variables and controls. } \\
\text { The authors obtain the data } \\
\text { from several sources. Tax } \\
\text { fees data is gathered from the } \\
\text { Audit Analytics database, } \\
\text { analyst forecast data is } \\
\text { obtained from the I/B/E/S } \\
\text { database, and financial data is } \\
\text { collected from the Compustat } \\
\text { database. } \\
\text { The authors exclude }\end{array}$ & $\begin{array}{l}\text { The authors find that higher tax services } \\
\text { fees paid to auditors are associated with } \\
\text { greater reductions in third to fourth } \\
\text { quarters effective tax rates (ETRs) for } \\
\text { companies that would miss consensus } \\
\text { earnings forecasts in the absence of tax } \\
\text { expense management. Further, they also } \\
\text { find that among companies that do not } \\
\text { purchase auditor provided tax services, } \\
\text { those that would miss consensus earnings } \\
\text { forecast absent ETR changes, the ETR } \\
\text { decreases are larger than for other } \\
\text { companies. Furthermore, the authors find } \\
\text { that tax fees paid to auditors are associated } \\
\text { with larger third to fourth quarter ETR }\end{array}$ \\
\hline
\end{tabular}




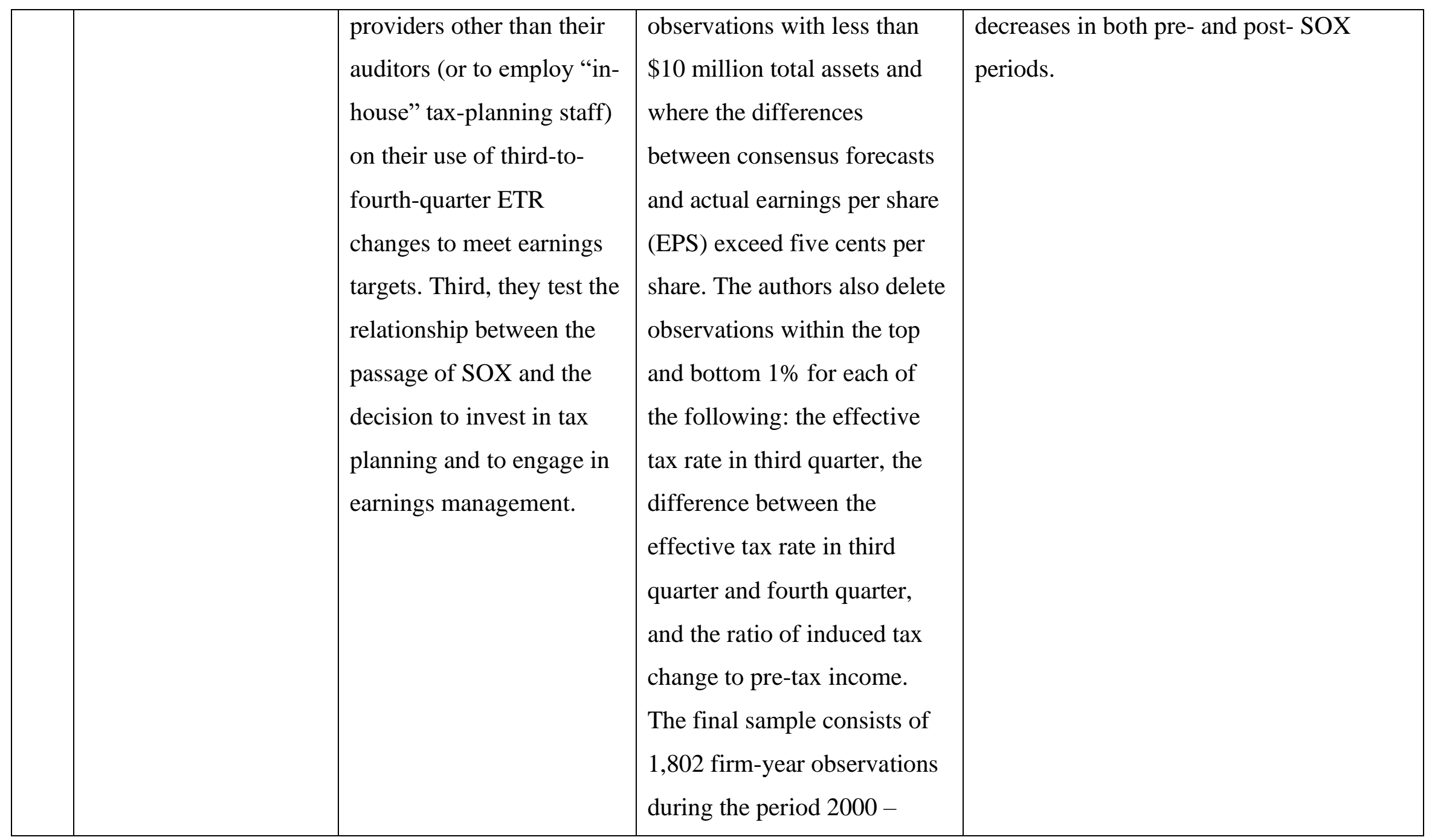




\begin{tabular}{|c|c|c|c|c|}
\hline & & & 2004. & \\
\hline 8 & $\begin{array}{l}\text { Davydenko, S. A., } \\
\text { Strebulaev, I. A., \& } \\
\text { Zhao, X. (2012). A } \\
\text { Market-Based Study of } \\
\text { the Cost of Default. } \\
\text { The Review of } \\
\text { Financial Studies, 25, } \\
\text { 2959-2999. }\end{array}$ & $\begin{array}{l}\text { The authors propose a } \\
\text { novel approach to } \\
\text { estimation of the cost of } \\
\text { default. The authors infer } \\
\text { the cost of default from the } \\
\text { change in the market value } \\
\text { of firms' assets upon } \\
\text { default. }\end{array}$ & $\begin{array}{l}\text { The authors use a generalized } \\
\text { form of event study } \\
\text { methodology. } \\
\text { They use a sample of } \\
\text { defaulting and non-defaulting } \\
\text { firm-month observations to } \\
\text { compute the risk premium } \\
\text { from observed debt prices } \\
\text { which is used to transform the } \\
\text { hazard rate to the risk-neutral } \\
\text { measure. Finally, they use an } \\
\text { iterative procedure to } \\
\text { estimate the continuation } \\
\text { value of the firm. } \\
\text { They use default data from } \\
\text { the Default \& Recovery }\end{array}$ & $\begin{array}{l}\text { They argue that investors do not fully } \\
\text { anticipate default in their decisions. } \\
\text { Consequently, public announcement of } \\
\text { default will contain information prompting } \\
\text { investors to correct their valuations. The } \\
\text { correction, therefore, reflects both the cost } \\
\text { of default and the unanticipated default } \\
\text { news. } \\
\text { They find that for an average defaulting } \\
\text { firm, the mean (median) of cost of default } \\
\text { is } 21.7 \% \text { ( } 22.1 \% \text { ) of the market value of } \\
\text { assets. Specifically, the cost of a distressed } \\
\text { bond exchange is } 14.7 \% \text {, while it is } 30.5 \% \\
\text { for bankruptcy. Moreover, they find that } \\
\text { the cost of default of highly leveraged } \\
\text { firms and investment-grade firms is } 20.2 \% \\
\text { and } 28.8 \% \text {, respectively. They also find }\end{array}$ \\
\hline
\end{tabular}




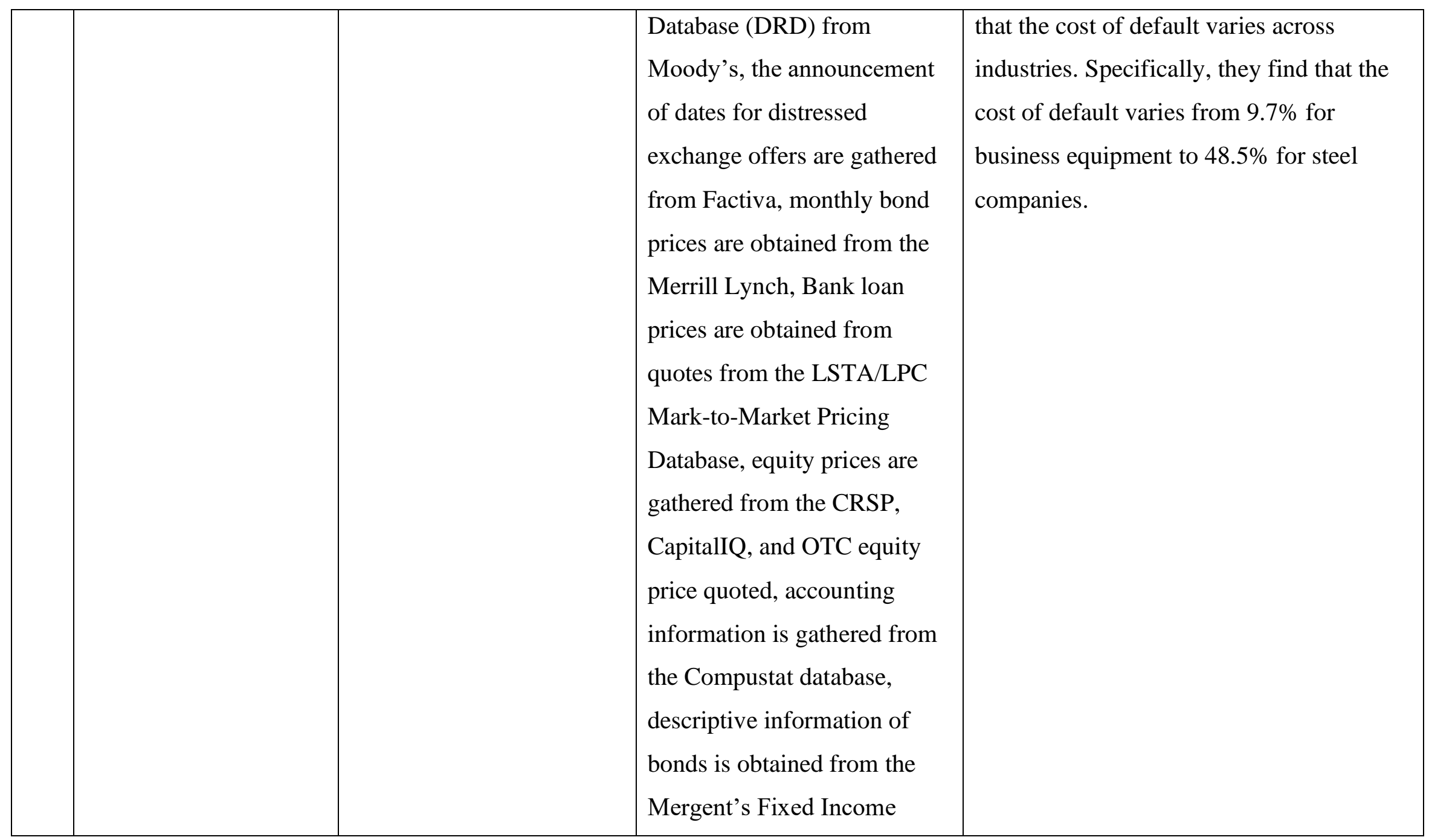




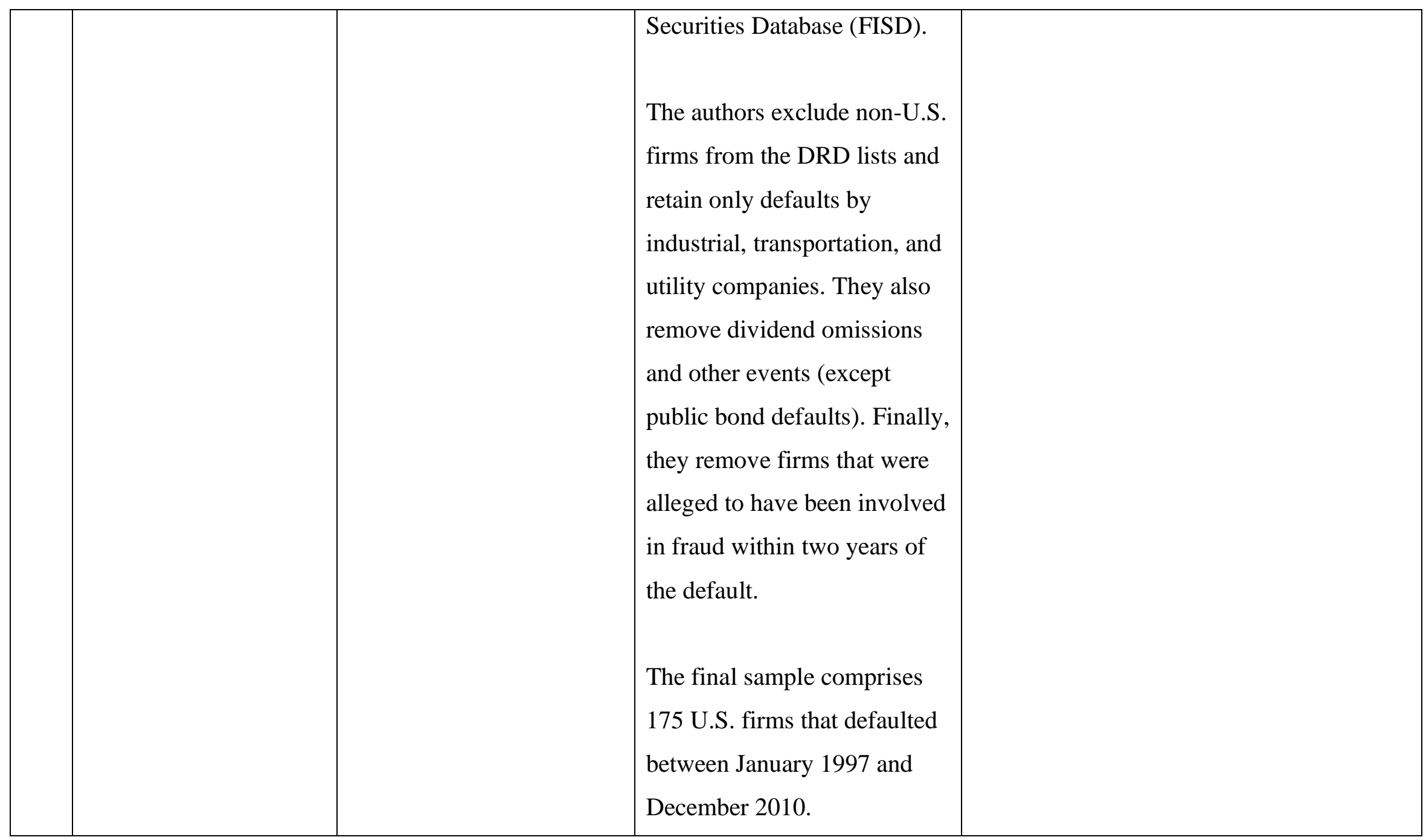




\begin{tabular}{|c|c|c|c|c|}
\hline 9 & $\begin{array}{l}\text { De Simone, L., Ege, M. } \\
\text { S., \& Stomberg, B. } \\
\text { (2015). Internal Control } \\
\text { Quality: The Role of } \\
\text { Auditor-Provided Tax } \\
\text { Services. The } \\
\text { Accounting Review, } \\
\text { 90, 1469-1496. }\end{array}$ & $\begin{array}{l}\text { The authors examine two } \\
\text { issues. First, they examine } \\
\text { whether auditor provided } \\
\text { tax services improve } \\
\text { firms' internal control } \\
\text { quality. Second, they } \\
\text { search for factors that can } \\
\text { strengthen the potential } \\
\text { benefits of auditor } \\
\text { provided tax services on } \\
\text { improving firms' internal } \\
\text { control quality. }\end{array}$ & $\begin{array}{l}\text { The authors use regression } \\
\text { analysis to link the test } \\
\text { variables and controls. } \\
\text { The sample consists of } \\
32,048 \text { firm-year observations } \\
\text { on } 5,830 \text { U.S. firms over the } \\
\text { period } 2004 \text { - } 2012 \text {. } \\
\text { The authors rely on the Audit } \\
\text { Analytics database to obtain } \\
\text { auditor internal control } \\
\text { opinions. Accounting } \\
\text { information is obtained from } \\
\text { the Compustat and CRSP } \\
\text { database. }\end{array}$ & $\begin{array}{l}\text { The authors argue that purchase of auditor } \\
\text { provided tax services facilitates earlier } \\
\text { assessment by the audit firms of the } \\
\text { internal control environment relating to } \\
\text { material transactions. Firms thus have } \\
\text { higher possibility of mitigating internal } \\
\text { control deficiencies and preventing } \\
\text { material weaknesses. They also argue that } \\
\text { providing tax services increases the } \\
\text { opportunity for communication between } \\
\text { tax partner, audit partner, and audit team } \\
\text { which may improve the identification of } \\
\text { client's internal control weakness. } \\
\text { Consequently, it may lower the likelihood } \\
\text { of material weakness being discovered at } \\
\text { year-end. }\end{array}$ \\
\hline
\end{tabular}




\begin{tabular}{|c|c|c|c|c|}
\hline & & & & $\begin{array}{l}\text { disclosure of material weaknesses but that } \\
\text { this is not impairment of auditor } \\
\text { independence. Rather they point to internal } \\
\text { control quality as a mechanism through } \\
\text { which auditor provided tax services } \\
\text { improve overall financial reporting quality. }\end{array}$ \\
\hline 10 & $\begin{array}{l}\text { Dharmapala, D., \& } \\
\text { Riedel, N. (2013). } \\
\text { Earnings shocks and } \\
\text { tax-motivated income- } \\
\text { shifting: Evidence from } \\
\text { European } \\
\text { multinationals. Journal } \\
\text { of Public Economics, } \\
\text { 97(Supplement C), 95- } \\
\text { 107. }\end{array}$ & $\begin{array}{l}\text { The authors investigate the } \\
\text { income shifting behaviour } \\
\text { of multinationals using a } \\
\text { new approach. } \\
\text { Specifically, they develop } \\
\text { an approach to estimate } \\
\text { the existence and } \\
\text { magnitude of tax- } \\
\text { motivated income shifting } \\
\text { by exploiting exogenous } \\
\text { earnings shocks to the } \\
\text { parent firm and investigate } \\
\text { how these shocks }\end{array}$ & $\begin{array}{l}\text { The authors develop a } \\
\text { mathematical model and use } \\
\text { difference-in-difference test. } \\
\text { The authors rely on the } \\
\text { AMADEUS database to } \\
\text { gather } 18,408 \text { observations } \\
\text { from } 1,806 \text { subsidiaries } \\
\text { during the period } 1995 \text { - } \\
2005 \text { for all EU-25 countries, } \\
\text { except Cyprus, Malta, and } \\
\text { Slovenia. }\end{array}$ & $\begin{array}{l}\text { Overall, the authors find that positive } \\
\text { earnings shocks for the parent companies } \\
\text { are more strongly related to the increase in } \\
\text { pre-tax income of subsidiaries in low-tax } \\
\text { countries compared to the pre-tax income } \\
\text { of high-tax affiliates. Furthermore, they } \\
\text { find that the estimated effect is mostly } \\
\text { related to the strategic use of debt across } \\
\text { affiliates. }\end{array}$ \\
\hline
\end{tabular}




\begin{tabular}{|c|c|c|c|c|}
\hline & & $\begin{array}{l}\text { propagate across low-tax } \\
\text { and high-tax multinational } \\
\text { subsidiaries. }\end{array}$ & $\begin{array}{l}\text { They include only } \\
\text { multinational subsidiaries } \\
\text { where the immediate } \\
\text { shareholder (parent) owns at } \\
\text { least a } 90 \% \text { stake in the } \\
\text { subsidiaries and the parent is } \\
\text { also located in an EU-25 } \\
\text { country. They also restrict the } \\
\text { firms to have positive pre-tax } \\
\text { income and more than } 5 \\
\text { employees. }\end{array}$ & \\
\hline 11 & $\begin{array}{l}\text { Dyreng, S. D., \& } \\
\text { Markle, K. S. (2016). } \\
\text { The Effect of Financial } \\
\text { Constraints on Income } \\
\text { Shifting by U.S. } \\
\text { Multinationals. The } \\
\text { Accounting Review, } \\
\text { 91(6), 1601-1627. }\end{array}$ & $\begin{array}{l}\text { The authors develop a new } \\
\text { methodology to measure } \\
\text { income shifting and } \\
\text { examine the influence of } \\
\text { financial constraints on } \\
\text { income shifting. }\end{array}$ & $\begin{array}{l}\text { The authors develop a } \\
\text { mathematical model to } \\
\text { analyze income shifting and } \\
\text { use regression analysis to link } \\
\text { the test variables and } \\
\text { controls. } \\
\text { The sample consists of U.S. }\end{array}$ & $\begin{array}{l}\text { Consistent with the authors expectation, } \\
\text { they find that financially constrained firms } \\
\text { shift less income from the U.S. to foreign } \\
\text { countries than do their unconstrained } \\
\text { peers. They estimate that financially } \\
\text { constrained firms shift out } 20 \% \text { less of pre- } \\
\text { shifted income than do unconstrained } \\
\text { firms. In dollar term, the mean (median) }\end{array}$ \\
\hline
\end{tabular}




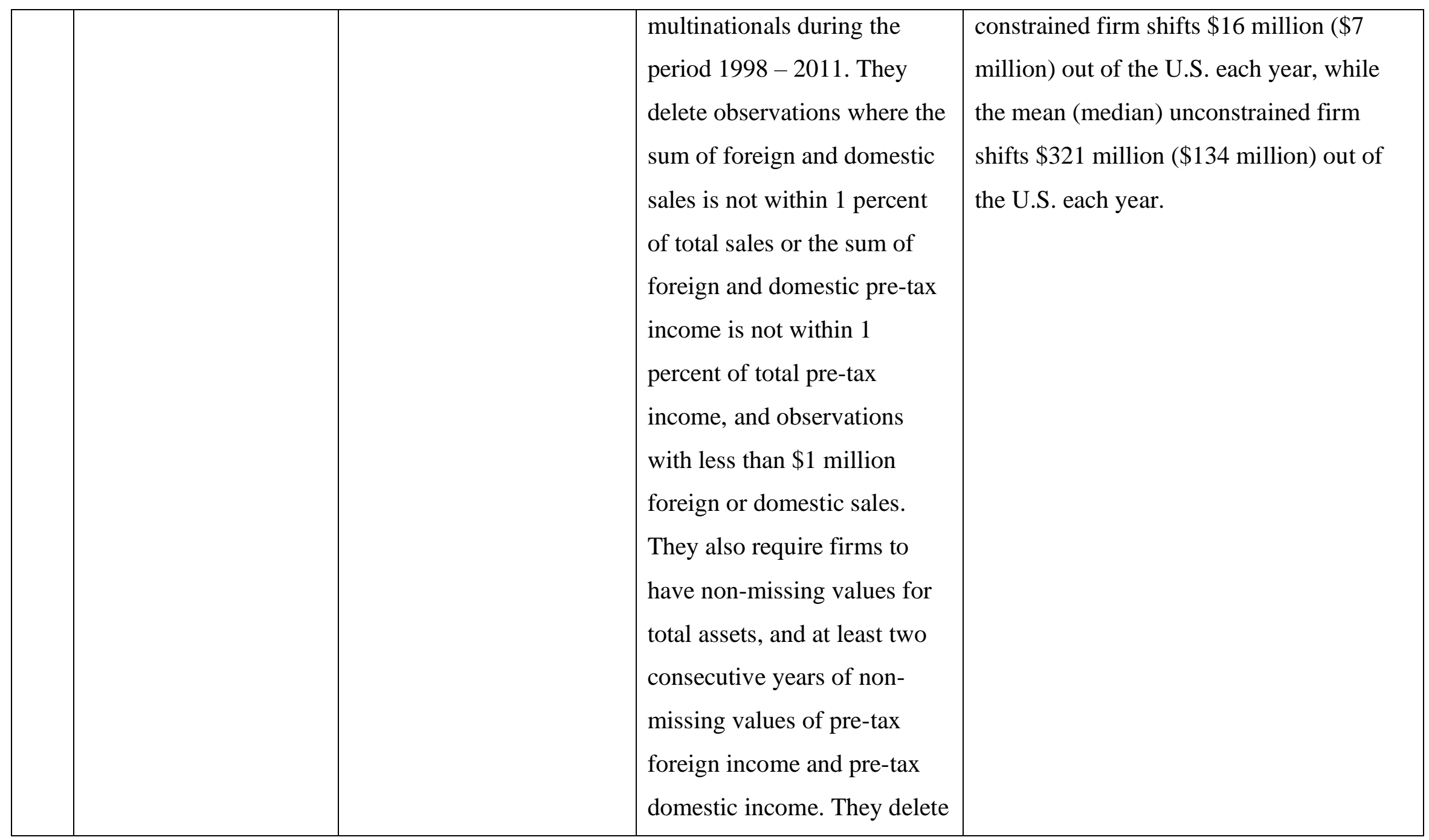




\begin{tabular}{|c|c|c|c|c|}
\hline & & & $\begin{array}{l}\text { flow-through entities, } \\
\text { financial, and utility firms. } \\
\text { They delete observations with } \\
\text { relatively large interest } \\
\text { revenues or special items and } \\
\text { other non-operating income } \\
\text { (either item in excess of } 10 \\
\text { percent of sales). Finally, } \\
\text { they drop observations with } \\
\text { total assets in the current or } \\
\text { previous year less than } \$ 1 \\
\text { million. The final sample } \\
\text { comprises } 9,727 \text { firm-year } \\
\text { observations. }\end{array}$ & \\
\hline 12 & $\begin{array}{l}\text { Ferguson, M. J., Seow, } \\
\text { G. S., \& Young, D. } \\
\text { (2004). Nonaudit } \\
\text { Services and Earnings } \\
\text { Management: UK }\end{array}$ & $\begin{array}{l}\text { The authors extend } \\
\text { previous research by } \\
\text { investigating the } \\
\text { relationship between the } \\
\text { auditor joint provision of }\end{array}$ & $\begin{array}{l}\text { The authors use regression } \\
\text { analysis to link the test } \\
\text { variables and controls. } \\
\text { The authors use three }\end{array}$ & $\begin{array}{l}\text { The authors extend the extant literature by } \\
\text { addressing several potential } \\
\text { methodological and data-related } \\
\text { limitations in prior studies. First, they use } \\
\text { alternative measures of earnings }\end{array}$ \\
\hline
\end{tabular}




\begin{tabular}{|c|c|c|c|}
\hline $\begin{array}{l}\text { Evidence. } \\
\text { Contemporary } \\
\text { Accounting Research, } \\
21,813-841 .\end{array}$ & $\begin{array}{l}\text { audit and non-audit } \\
\text { services and earnings } \\
\text { management using data on } \\
\text { United Kingdom firms. }\end{array}$ & $\begin{array}{l}\text { alternative measures of } \\
\text { earnings management and } \\
\text { three alternative measures of } \\
\text { non-audit services (ratio of } \\
\text { non-audit services to total } \\
\text { fees, natural log of non-audit } \\
\text { services, and decile rank, by } \\
\text { audit firm practice office, of } \\
\text { non-audit services fees paid } \\
\text { by clients). } \\
\text { The sample data is obtained } \\
\text { from the Global Vantage } \\
\text { database. The authors exclude } \\
\text { firms in industries with less } \\
\text { than eight firms, financial } \\
\text { firms, and firms with less } \\
\text { than two annual reports } \\
\text { during the period } 1996 \text { - }\end{array}$ & $\begin{array}{l}\text { management namely the likelihood of } \\
\text { criticism by financial analyst and } \\
\text { investors, regulatory investigation of firm } \\
\text { accounting practices, restatement of prior } \\
\text { financial statements or adjustment of } \\
\text { current period results, following the } \\
\text { issuance of FRS No.12: Provisions, } \\
\text { contingent liabilities, and contingent } \\
\text { assets. Second, as prior studies mostly use } \\
\text { a single period subsequent to February } \\
2001 \text {, accruals are likely to have been } \\
\text { affected by the global economic downturn } \\
\text { that happened during that period. The } \\
\text { authors address that issue by using United } \\
\text { Kingdom data from period } 1996 \text { - } 1998 \\
\text { when the economic environment was } \\
\text { stable. Third, the authors mitigate the } \\
\text { possibility that the threat to auditor } \\
\text { independence is a result of recurring non- }\end{array}$ \\
\hline
\end{tabular}




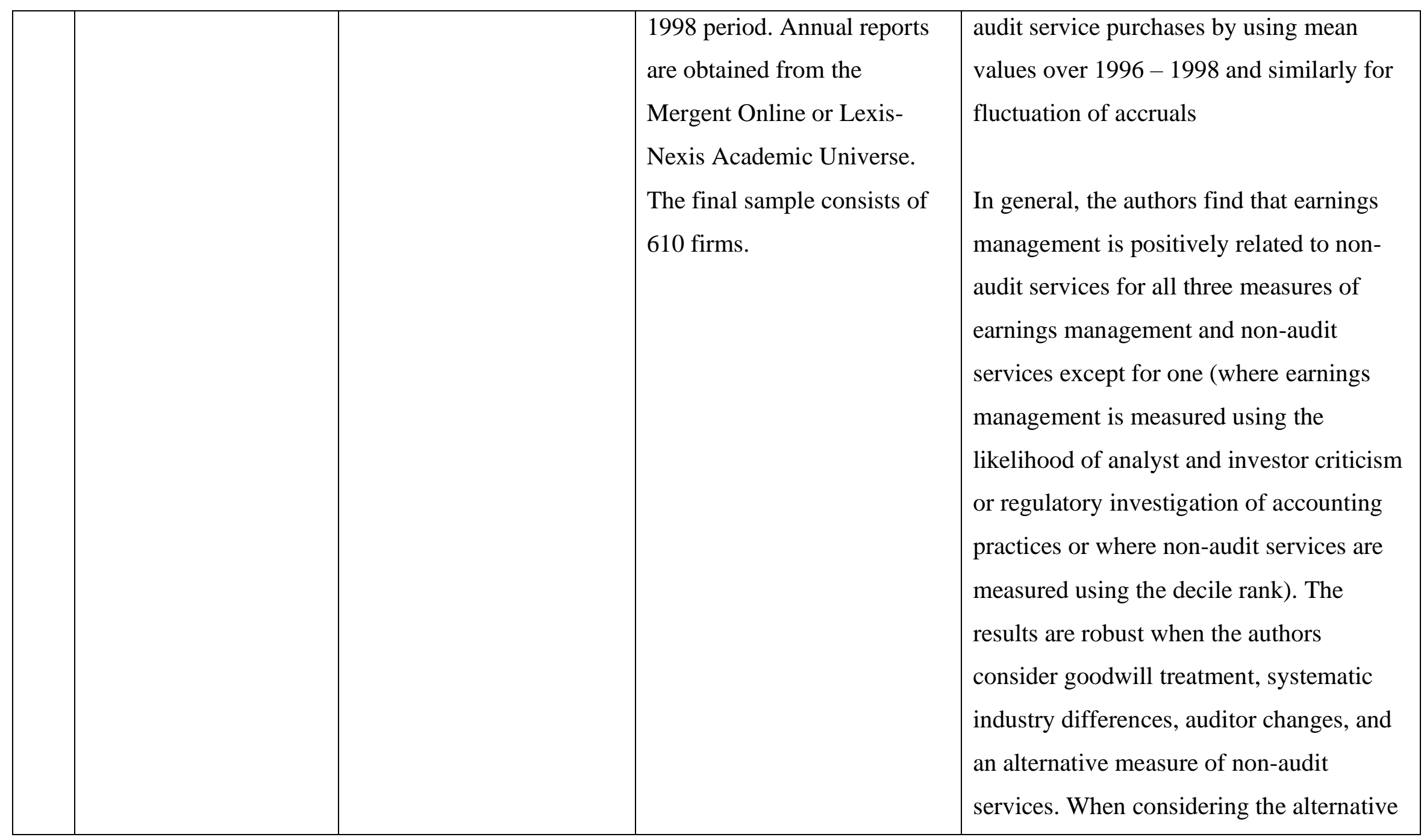




\begin{tabular}{|c|c|c|c|c|}
\hline & & & & $\begin{array}{l}\text { specifications of restatements, they find } \\
\text { that the association between non-audit } \\
\text { services and restatements depends on } \\
\text { whether the restatements relate to earnings } \\
\text { or the balance sheet. Specifically, they find } \\
\text { robust evidence that non-audit services are } \\
\text { positively related to earnings-related } \\
\text { restatements, for all three measures of non- } \\
\text { audit services used in the study. However, } \\
\text { they find a positive relationship between } \\
\text { non-audit services and balance sheet } \\
\text { related restatements for only one of the } \\
\text { three measures, namely log of non-audit } \\
\text { fees. }\end{array}$ \\
\hline 13 & $\begin{array}{l}\text { Fortin, S., \& Pittman, J. } \\
\text { A. (2008). The Impact } \\
\text { of Auditor-Related Tax } \\
\text { Services on Corporate } \\
\text { Debt Pricing. Journal of }\end{array}$ & $\begin{array}{l}\text { The authors investigate the } \\
\text { value of auditor provided } \\
\text { tax services in respect of } \\
\text { bondholders. }\end{array}$ & $\begin{array}{l}\text { The authors use regression } \\
\text { analysis to link the test } \\
\text { variables and controls. } \\
\text { The authors use the Thomson }\end{array}$ & $\begin{array}{l}\text { The authors find a lower yield spreads for } \\
\text { firms that pay proportionately larger tax } \\
\text { fees to their auditor. Their result is } \\
\text { economically significant where one } \\
\text { standard deviation increase in the ratio of }\end{array}$ \\
\hline
\end{tabular}




\begin{tabular}{|c|c|c|}
\hline $\begin{array}{l}\text { the American Taxation } \\
\text { Association, 30(2), 79- } \\
106 .\end{array}$ & $\begin{array}{l}\text { Financial's SDC Platinum } \\
\text { U.S. New Issues database to } \\
\text { gather all public bonds issue } \\
\text { during January 1, } 2001 \text { - } \\
\text { December } 31,2005 \text {. The } \\
\text { authors then merge that data } \\
\text { with firm-specific financial } \\
\text { data from the Compustat } \\
\text { database and hand collected } \\
\text { data from SEC filings. The } \\
\text { authors restrict the sample to } \\
\text { only new public debt issues } \\
\text { and straight bonds with fixed } \\
\text { rates. The final sample } \\
\text { consists of } 694 \text { public debt } \\
\text { issues. }\end{array}$ & $\begin{array}{l}\text { tax fees to the sum of audit fees and audit- } \\
\text { related fees result in a } 6 \text { basis points } \\
\text { decrease of yield spreads. } \\
\text { Further, they find that the negative } \\
\text { relationship between auditor provided tax } \\
\text { services and yield spread is more } \\
\text { pronounced when they isolate issues made } \\
\text { by firms with greater information } \\
\text { asymmetry. Specifically, they find that the } \\
\text { negative relationship is stronger for shorter } \\
\text { maturity bonds and financial firms. } \\
\text { They argue that their results provide } \\
\text { evidence of the positive effects of auditor } \\
\text { provided tax services, such as knowledge } \\
\text { spillover, overcome the negative effects } \\
\text { such as impairment of auditor } \\
\text { independence. }\end{array}$ \\
\hline
\end{tabular}




\begin{tabular}{|c|c|c|c|c|}
\hline 14 & $\begin{array}{l}\text { Francis, J. R., \& Ke, B. } \\
\text { (2006). Disclosure of } \\
\text { fees paid to auditors } \\
\text { and the market } \\
\text { valuation of earnings } \\
\text { surprises. Review of } \\
\text { Accounting Studies, } \\
\text { 11, 495-523. }\end{array}$ & $\begin{array}{l}\text { The authors investigate the } \\
\text { effect of mandated fees } \\
\text { disclosure on market } \\
\text { perception of auditor } \\
\text { independence and earnings } \\
\text { quality. }\end{array}$ & $\begin{array}{l}\text { The authors use regression } \\
\text { analysis to link the test } \\
\text { variables and controls } \\
\text { (difference-in-difference } \\
\text { analysis). } \\
\text { The authors examine the } \\
\text { issue by exploiting the market } \\
\text { response to quarterly earnings } \\
\text { in the year before and after } \\
\text { the initial fees disclosure and } \\
\text { test whether non-audit fees } \\
\text { can explain the market } \\
\text { response in those two periods. } \\
\text { The authors rely on several } \\
\text { data sources such as the SEC } \\
\text { EDGAR, Standard and } \\
\text { Poor's, The Emerson }\end{array}$ & $\begin{array}{l}\text { The authors argue that if fees disclosure } \\
\text { contains new information for investors and } \\
\text { if they believe that non-audit services may } \\
\text { impair auditor independence, then } \\
\text { investors will value the earnings of firms } \\
\text { with higher non-audit fees lower than } \\
\text { firms with lower non-audit fees. } \\
\text { The authors find that, in the period before } \\
\text { fees disclosure, investors do not discount } \\
\text { the earnings of firms that subsequently } \\
\text { report high non-audit fees. In contrast, in } \\
\text { the year after fees disclosure, the earnings } \\
\text { response coefficient of firms with higher } \\
\text { non-audit fees is lower than those with } \\
\text { lower non-audit fees. The results are robust } \\
\text { to excluding Big5 clients and excluding } \\
\text { earnings announcements after } 11 \\
\text { September } 2001 \text {. The results are also }\end{array}$ \\
\hline
\end{tabular}




\begin{tabular}{|c|c|c|c|c|}
\hline & & & $\begin{array}{l}\text { Company, CRSP, Compustat, } \\
\text { and I/B/E/S. They limit the } \\
\text { sample to earnings } \\
\text { announcement made within } 1 \\
\text { year of the firm initial proxy } \\
\text { statement fees disclosure } \\
\text { date. The final sample is } \\
\text { 16,910 firm-quarter } \\
\text { observations on 3,133 U.S. } \\
\text { firms over the period 1999- } \\
2002 \text {. }\end{array}$ & $\begin{array}{l}\text { robust to controlling for earnings } \\
\text { persistence, systematic risk, and growth } \\
\text { opportunities. They argue that the results } \\
\text { indicate that fees disclosures provide new } \\
\text { information and the market perceives that } \\
\text { higher non-audit fees potentially impair } \\
\text { auditor independence. }\end{array}$ \\
\hline 15 & $\begin{array}{l}\text { Frankel, R. M., } \\
\text { Johnson, M. F., Nelson, } \\
\text { K. K., Kinney, J., \& } \\
\text { Libby, R. (2002). The } \\
\text { relationship between } \\
\text { auditors' fees for } \\
\text { nonaudit services and }\end{array}$ & $\begin{array}{l}\text { The authors examine } \\
\text { whether the provision of } \\
\text { non-audit services is } \\
\text { related to earnings } \\
\text { management and market } \\
\text { reactions to the disclosure } \\
\text { of auditor fees. }\end{array}$ & $\begin{array}{l}\text { The authors use regression } \\
\text { analysis to link the test } \\
\text { variables and controls. } \\
\text { The initial sample is based on } \\
\text { proxy statements on the SEC } \\
\text { EDGAR database with a }\end{array}$ & $\begin{array}{l}\text { The authors find a positive relationship } \\
\text { between non-audit services and the } \\
\text { likelihood of reporting small earnings } \\
\text { surprise, the magnitude of absolute } \\
\text { discretionary accruals, and the magnitude } \\
\text { of income-increasing and income- } \\
\text { decreasing discretionary accruals. }\end{array}$ \\
\hline
\end{tabular}




\begin{tabular}{|c|c|c|}
\hline $\begin{array}{l}\text { earnings management. } \\
\text { The Accounting } \\
\text { Review, 77, 71-114. }\end{array}$ & $\begin{array}{l}\text { filing date between } 5 \text { th } \\
\text { February } 2001-15_{\text {th }} \text { June } \\
\text { 2001. The authors exclude } \\
\text { financial firms and firms that } \\
\text { changed auditor during the } \\
\text { year. The authors then match } \\
\text { the data with the Compustat } \\
\text { database. The final sample is } \\
3,074 \text { firms. The authors use } \\
\text { the CRSP database to } \\
\text { calculate abnormal returns. }\end{array}$ & $\begin{array}{l}\text { However, they do not find a significant } \\
\text { relationship between non-audit services } \\
\text { and small earnings surprise for larger } \\
\text { firms. They also fail to find a relationship } \\
\text { between non-audit services and the } \\
\text { likelihood of reporting small increase in } \\
\text { earnings. Overall, they conclude that the } \\
\text { result provides evidence that firms } \\
\text { purchasing non-audit services engage in a } \\
\text { greater degree of earnings management } \\
\text { than do other firms. } \\
\text { In addition, they find that audit fees are } \\
\text { negatively related to earnings } \\
\text { management. They also find a significant } \\
\text { negative relationship between abnormal } \\
\text { returns and the disclosure of higher than } \\
\text { expected non-audit fees. However, that } \\
\text { relationship does not hold when longer }\end{array}$ \\
\hline
\end{tabular}




\begin{tabular}{|c|c|c|c|c|}
\hline & & & & $\begin{array}{l}\text { event windows are used to measure } \\
\text { abnormal returns. }\end{array}$ \\
\hline 16 & $\begin{array}{l}\text { Gaynor, L. M., } \\
\text { McDaniel, L. S., \& } \\
\text { Neal, T. L. (2006). The } \\
\text { Effects of Joint } \\
\text { Provision and } \\
\text { Disclosure of Nonaudit } \\
\text { Services on Audit } \\
\text { Committee Members' } \\
\text { Decisions and } \\
\text { Investors' Preferences. } \\
\text { The Accounting } \\
\text { Review, 81, 873-896. }\end{array}$ & $\begin{array}{l}\text { The authors examine the } \\
\text { effect of mandatory } \\
\text { disclosure requirement on } \\
\text { the decision of audit } \\
\text { committees to use non- } \\
\text { audit services. They } \\
\text { investigate three issues } \\
\text { related to the } \\
\text { consequences of the } \\
\text { Sarbanes-Oxley Act of } \\
2002 \text { and the mandatory } \\
\text { disclosure requirement on } \\
\text { audit practices. First, } \\
\text { whether audit committees } \\
\text { consider the effect of non- } \\
\text { audit services on audit } \\
\text { quality when they decide }\end{array}$ & $\begin{array}{l}\text { This study uses a } 2 \text { x } 2 \\
\text { between participants } \\
\text { experimental research } \\
\text { method. In the } 2 \text { x } 2 \text { approach } \\
\text { used, the authors manipulate } \\
\text { the type of non-audit service } \\
\text { (risk management service } \\
\text { versus human resource } \\
\text { management service) and the } \\
\text { type of company (private } \\
\text { versus public). Further, the } \\
\text { authors also use regression } \\
\text { analysis. } \\
\text { The study uses } 100 \text { corporate } \\
\text { directors who attended one of } \\
12 \text { different KPMG Audit }\end{array}$ & $\begin{array}{l}\text { The authors find that the decision of audit } \\
\text { committees to recommend the joint } \\
\text { provision of audit and non-audit services } \\
\text { by auditors is affected by their perception } \\
\text { of the effect of the joint provision on audit } \\
\text { quality. They find that both audit } \\
\text { committees and investors are more likely } \\
\text { to recommend the joint provision if it } \\
\text { improves audit quality. However, the } \\
\text { authors find that public disclosure lowers } \\
\text { the likelihood of audit committees } \\
\text { approving the joint provision, even when } \\
\text { they believe that the joint provision may } \\
\text { result improvement in audit quality. }\end{array}$ \\
\hline
\end{tabular}




\begin{tabular}{|c|c|c|c|c|}
\hline & & $\begin{array}{l}\text { to approve non-audit } \\
\text { services from the auditor. } \\
\text { Second, how the mandated } \\
\text { disclosures influence audit } \\
\text { committees' pre-approval } \\
\text { decisions. Third, how } \\
\text { consistent the decisions of } \\
\text { audit committees are with } \\
\text { investors' preferences on } \\
\text { the auditors' joint } \\
\text { provision of audit and non- } \\
\text { audit services. }\end{array}$ & $\begin{array}{l}\text { Committee Institute } \\
\text { Roundtables around the U.S. } \\
\text { during 2003. In the } \\
\text { experiment, } 81 \text { act as audit } \\
\text { committee members to } \\
\text { recommend whether auditor } \\
\text { should provide non-audit } \\
\text { services and the remaining } 19 \\
\text { act as public company } \\
\text { investors to express } \\
\text { preferences regarding auditor } \\
\text { provision of risk management } \\
\text { services. }\end{array}$ & \\
\hline 17 & $\begin{array}{l}\text { Giesecke, K., } \\
\text { Longstaff, F. A., } \\
\text { Schaefer, S., \& } \\
\text { Strebulaev, I. (2011). } \\
\text { Corporate bond default } \\
\text { risk: A 150-year }\end{array}$ & $\begin{array}{l}\text { The authors examine U.S. } \\
\text { corporate bond default } \\
\text { rates using a new data set } \\
\text { over the period } 1866 \text { to } \\
2008 \text {. }\end{array}$ & $\begin{array}{l}\text { Using financial and } \\
\text { macroeconomics variables, } \\
\text { the authors use the fraction of } \\
\text { the total par value of the } \\
\text { corporate bond market that } \\
\text { enters into financial distress }\end{array}$ & $\begin{array}{l}\text { They find that default rates may be } \\
\text { predicted using stock market returns, } \\
\text { changes in stock market volatility, and } \\
\text { changes in gross domestic product. } \\
\text { Surprisingly, they fail to find predictive } \\
\text { power for credit spreads. }\end{array}$ \\
\hline
\end{tabular}




\begin{tabular}{|c|c|c|c|}
\hline $\begin{array}{l}\text { perspective. Journal of } \\
\text { Financial Economics, } \\
102,233-250 \text {. }\end{array}$ & $\begin{array}{l}\text { The authors specifically } \\
\text { examine the issue of bonds } \\
\text { issued by U.S. firms in } \\
\text { non-financial sectors. }\end{array}$ & $\begin{array}{l}\text { during each year of the } \\
\text { sample period to measure } \\
\text { default rates. Specifically, } \\
\text { they use a three-state } \\
\text { Markov-chain regime- } \\
\text { switching model to examine } \\
\text { the marginal effect of } \\
\text { financial and } \\
\text { macroeconomics variables to } \\
\text { explain variation in default } \\
\text { rates. } \\
\text { The authors rely on several } \\
\text { data sources to gather their } \\
\text { sample. Data for the period } \\
1866 \text { - } 1899 \text { is obtained from } \\
\text { the Commercial and Financial } \\
\text { Chronicle (CFC), data for the } \\
\text { period } 1900 \text { - } 1965 \text { is taken }\end{array}$ & $\begin{array}{l}\text { They find that the bond market has } \\
\text { experienced several clustered default } \\
\text { events. Among those events, the worse } \\
\text { event occurred during the railroad crisis in } \\
\text { the years } 1873 \text { - } 1875 \text {. They find that the } \\
\text { default rate was more than one-third of the } \\
\text { total par value of the corporate bond } \\
\text { market during that period. Interestingly, } \\
\text { they find that the worst three years of the } \\
\text { great depression, } 1933 \text { - } 1935 \text {, only ranks } \\
\text { fourth with a default rate of } 12.88 \% \text {. }\end{array}$ \\
\hline
\end{tabular}




\begin{tabular}{|c|c|c|c|c|}
\hline & & & $\begin{array}{l}\text { from the National Bureau of } \\
\text { Economic Research (NBER), } \\
\text { and the remainders of the } \\
\text { data, } 1966 \text { - 2008, is obtained } \\
\text { from the Federal Reserve } \\
\text { Board, CFC, Standard and } \\
\text { Poor's, and Moody's } \\
\text { Investors Service. In addition, } \\
\text { they use data from the } \\
\text { Securities Industry and } \\
\text { Financial Market Association } \\
\text { (SIFMA). }\end{array}$ & \\
\hline 18 & $\begin{array}{l}\text { Gleason, C. A., \& } \\
\text { Mills, L. F. (2011). Do } \\
\text { Auditor-Provided Tax } \\
\text { Services Improve the } \\
\text { Estimate of Tax } \\
\text { Reserves?. } \\
\text { Contemporary }\end{array}$ & $\begin{array}{l}\text { The authors investigate the } \\
\text { association between } \\
\text { auditor provided tax } \\
\text { services and the ability of } \\
\text { firms to estimate their tax } \\
\text { reserve in the face of an } \\
\text { Internal Revenue Service }\end{array}$ & $\begin{array}{l}\text { The authors use regression } \\
\text { analysis to link the test } \\
\text { variables and controls. } \\
\text { The authors rely on several } \\
\text { data sources including S\&P } \\
\text { audit fees data, Compustat, }\end{array}$ & $\begin{array}{l}\text { The authors argue that the provision of tax } \\
\text { services by auditors may improve the } \\
\text { quality of audit work, and thereby better } \\
\text { financial reporting. If so, the knowledge } \\
\text { spillover effect may improve the adequacy } \\
\text { of the tax reserve. On the other hand, tax } \\
\text { work may impair audit quality if it leads to }\end{array}$ \\
\hline
\end{tabular}




\begin{tabular}{|c|c|c|c|}
\hline $\begin{array}{l}\text { Accounting Research, } \\
28,1484-1509 .\end{array}$ & (IRS) investigation. & $\begin{array}{l}\text { Large and MidSize Business } \\
\text { Tax Return Data, and IRS } \\
\text { examination data. The } \\
\text { authors delete firms with non- } \\
\text { complete IRS examination } \\
\text { data, and firms that change } \\
\text { their auditor during the } \\
\text { previous } 5 \text { years and the } \\
\text { current year. They also } \\
\text { exclude from the sample with } \\
\text { cases where the stock option } \\
\text { tax benefit is so large that the } \\
\text { tax paid on the return plus the } \\
\text { stock options tax benefit } \\
\text { minus current tax expense, } \\
\text { exceeds } 100 \% \text { of pre-tax } \\
\text { income. The final sample } \\
\text { comprises } 497 \text { firm-year } \\
\text { observations over the period }\end{array}$ & $\begin{array}{l}\text { lower auditor independence. In this case, } \\
\text { the authors argue that the decrease of } \\
\text { auditor independence may cause firms to } \\
\text { adjust their tax reserve to increase or } \\
\text { smooth their earnings. } \\
\text { The authors find that firms that purchase } \\
\text { auditor provided tax services are better } \\
\text { able to estimate the tax contingency and } \\
\text { thus have a lower tax reserve. The results } \\
\text { are consistent with the knowledge spillover } \\
\text { effect. They argue that it is an indication } \\
\text { that those firms must have booked an } \\
\text { adequate tax reserve. The result is robust to } \\
\text { the authors considering the identity of the } \\
\text { auditor. The authors also find that their } \\
\text { result is not driven by the possibility of } \\
\text { delaying the effect of tax contingencies } \\
\text { and intention of firms to smooth earnings }\end{array}$ \\
\hline
\end{tabular}




\begin{tabular}{|c|c|c|c|c|}
\hline & & & $2000-2002$ & using the tax reserve. \\
\hline 19 & $\begin{array}{l}\text { Gleason, C. A., Mills, } \\
\text { L. F., \& Nessa, M. L. } \\
\text { (2018). Does FIN } 48 \\
\text { Improve Firms' } \\
\text { Estimates of Tax } \\
\text { Reserves?. } \\
\text { Contemporary } \\
\text { Accounting Research, } \\
\text { 35, 1395-1429. }\end{array}$ & $\begin{array}{l}\text { The authors investigate the } \\
\text { adequacy and accuracy of } \\
\text { tax reserves in term of } \\
\text { Financial Accounting } \\
\text { Standards Board (FASB) } \\
\text { Interpretation No.48 and } \\
\text { the influence of auditor } \\
\text { provided tax services on } \\
\text { tax reserves. }\end{array}$ & $\begin{array}{l}\text { The authors use regression } \\
\text { analysis to link the test } \\
\text { variables and controls. } \\
\text { The authors gather the } \\
\text { financial data from the } \\
\text { Compustat database, auditor } \\
\text { fees are obtained from the } \\
\text { Audit Analytics database, and } \\
\text { analyst forecast data is } \\
\text { gathered from the I/B/E/S } \\
\text { database. They obtain the tax } \\
\text { return and IRS examination } \\
\text { data confidentially from the } \\
\text { IRS. The final sample is } \\
2,798 \text { firm-year observations } \\
\text { over the } 2003 \text { - } 2014 \text { period } \\
\text { covering a positive IRS }\end{array}$ & $\begin{array}{l}\text { The authors find that for both prior- and } \\
\text { post- FIN 48, firms are adequately } \\
\text { reserved for IRS tax assessments and } \\
\text { settlements. For both prior and post FIN } \\
\text { 48, firms adjust their tax reserve in the } \\
\text { year of IRS assessments and settlements. } \\
\text { They find that the overall adequacy or } \\
\text { accuracy of reserves pre- and post-FIN } 48 \\
\text { are not statistically different. } \\
\text { Related to the impact of auditor provided } \\
\text { tax services, they find that, overall, firms } \\
\text { with low APTS are under-reserved for IRS } \\
\text { assessments, while firms with high ATPS } \\
\text { are over-reserved prior to FIN } 48 \text {. } \\
\text { However, post-FIN } 48 \text {, there is no } \\
\text { difference between the adequacy of tax } \\
\text { reserves for firms with a high or low level }\end{array}$ \\
\hline
\end{tabular}




\begin{tabular}{|c|c|c|c|c|}
\hline & & & $\begin{array}{l}\text { proposed deficiency or IRS } \\
\text { settlement. }\end{array}$ & $\begin{array}{l}\text { of APTS. In that case, they argue that FIN } \\
48 \text { eliminates the knowledge spillover } \\
\text { benefit of APTS as it improves the } \\
\text { availability of information for firms with } \\
\text { low tax services. }\end{array}$ \\
\hline 20 & $\begin{array}{l}\text { Glover, B. (2016). The } \\
\text { expected cost of } \\
\text { default. Journal of } \\
\text { Financial Economics, } \\
\text { 119, 284-299. }\end{array}$ & $\begin{array}{l}\text { The author aims to } \\
\text { estimate firm-specific } \\
\text { expected default cost that } \\
\text { is not subject to selection } \\
\text { bias. }\end{array}$ & $\begin{array}{l}\text { The author uses a dynamic } \\
\text { capital structure model in } \\
\text { estimating the expected cost } \\
\text { of default. } \\
\text { The author uses 2,505 U.S. } \\
\text { public firms with at least } 20 \\
\text { quarters data available in the } \\
\text { CRSP and Compustat } \\
\text { database from 1947Q1 to } \\
\text { 2010Q2, excluding financials } \\
\text { and utilities firms. The author } \\
\text { uses quarterly aggregate } \\
\text { earnings data from the }\end{array}$ & $\begin{array}{l}\text { The author argues that the estimation of } \\
\text { the cost of default using defaulted firms is } \\
\text { subject to selection bias as firms with a } \\
\text { higher cost of default tend to choose a } \\
\text { lower level of leverage to mitigate default } \\
\text { risk. Consequently, defaulted firms are } \\
\text { those with a low cost of default. This } \\
\text { selection bias thereby underestimates the } \\
\text { default cost that is incurred during the } \\
\text { default period } \\
\text { The author finds that the mean (median) of } \\
\text { cost of default is } 45 \% \text { ( } 37 \% \text { ) of firm value. } \\
\text { Using only defaulted firms, the average }\end{array}$ \\
\hline
\end{tabular}




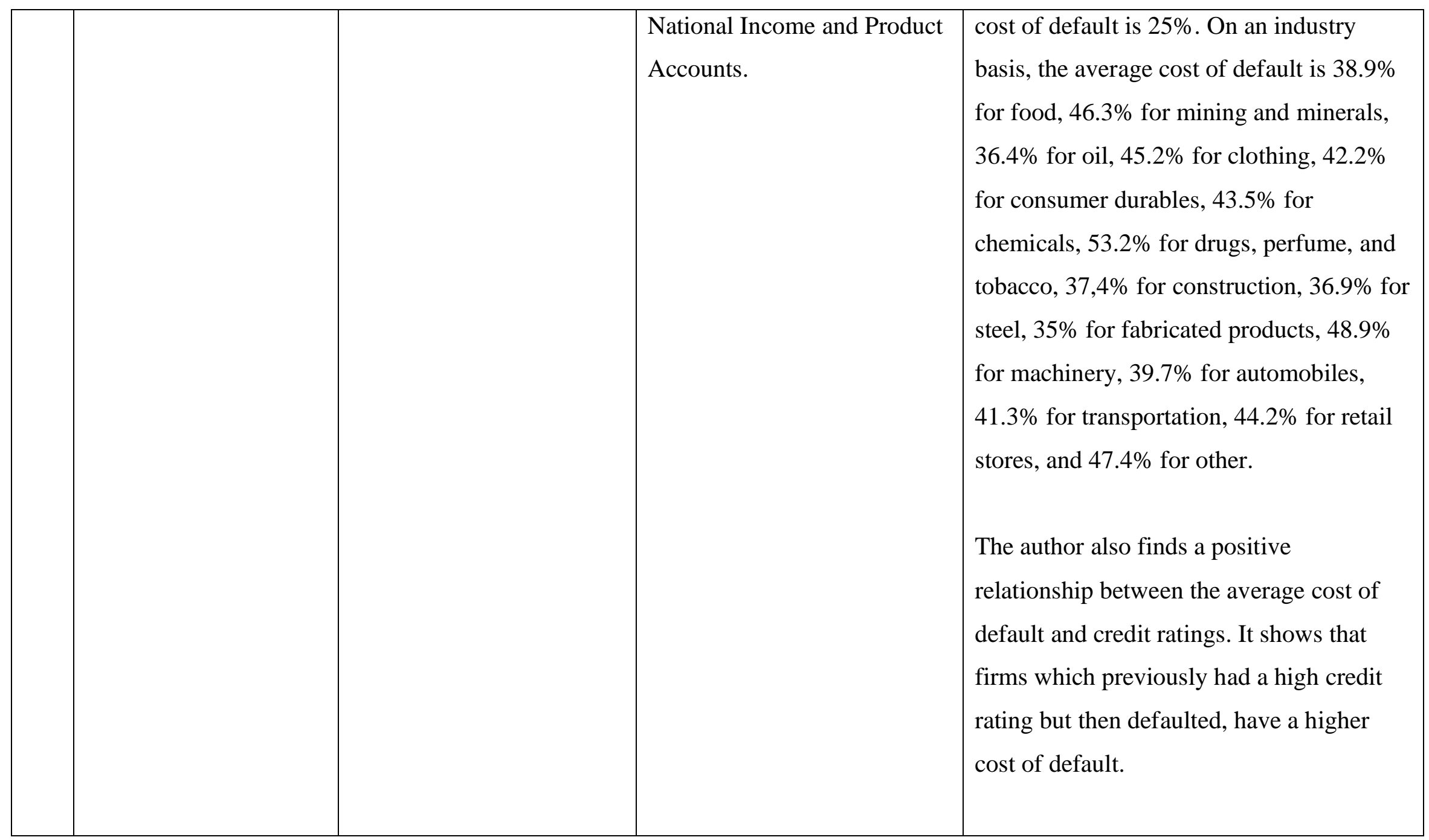




\begin{tabular}{|c|c|c|c|c|}
\hline & & & & $\begin{array}{l}\text { In addition, the author finds that firms with } \\
\text { higher market to book ratio and investment } \\
\text { rates have higher default cost. }\end{array}$ \\
\hline 21 & $\begin{array}{l}\text { Hsu, P. H., Lee, H. H., } \\
\text { Liu, A. Z., \& Zhang, Z. } \\
\text { (2015). Corporate } \\
\text { innovation, default risk, } \\
\text { and bond pricing. } \\
\text { Journal of Corporate } \\
\text { Finance, 35, 329-344. }\end{array}$ & $\begin{array}{l}\text { The authors examine how } \\
\text { innovation, as measured } \\
\text { using patent records, is } \\
\text { related to default risk and } \\
\text { bond pricing. } \\
\text { They argue that the effect } \\
\text { of corporate innovation on } \\
\text { the price of bond is } \\
\text { underexplored despite } \\
\text { corporate innovation } \\
\text { possibly determining the } \\
\text { credit risk profile and } \\
\text { bring an important } \\
\text { influence on firm value. } \\
\text { They are motivated to } \\
\text { explore the extent to which }\end{array}$ & $\begin{array}{l}\text { The authors use regression } \\
\text { analysis to link the test } \\
\text { variables and controls. } \\
\text { The sample consists of } 143 \\
\text { corporate bond issues by U.S. } \\
\text { firms over the period } 1976 \text { - } \\
\text { 2006. The authors gather } \\
\text { patents data from the updated } \\
\text { National Bureau of Economic } \\
\text { Research (NBER). They then } \\
\text { combine that data from the } \\
\text { Compustat and CRSP } \\
\text { databases. }\end{array}$ & $\begin{array}{l}\text { The authors argue that firms with more and } \\
\text { higher quality patents have greater } \\
\text { capacity to compete in the market. Hence, } \\
\text { they are more likely to obtain first mover } \\
\text { advantages and assume a market leader } \\
\text { role. In addition, patents may increase the } \\
\text { entry barriers for newcomers to the } \\
\text { business. All these positive factors would } \\
\text { improve firms' financial stability, thereby } \\
\text { reducing default risk. } \\
\text { Furthermore, they argue if corporate } \\
\text { innovation leads to lower default risk, } \\
\text { thereby improving firm's solvency, bond } \\
\text { investors may demand a lower risk } \\
\text { premium for firms with stronger }\end{array}$ \\
\hline
\end{tabular}




\begin{tabular}{|c|c|c|c|c|}
\hline & & $\begin{array}{l}\text { bond investors value these } \\
\text { corporate innovations. }\end{array}$ & & $\begin{array}{l}\text { innovation performances. } \\
\text { Consistent with their prediction, they find } \\
\text { that firms with more and higher impact } \\
\text { patents with higher generality and } \\
\text { originality scores are less likely to default. } \\
\text { They also find that innovative firms have } \\
\text { lower yield on newly issued bonds in the } \\
\text { primary market and lower excess bond } \\
\text { returns in the secondary market. }\end{array}$ \\
\hline 22 & $\begin{array}{l}\text { Kinney, W. R., } \\
\text { Palmrose, Z. V., \& } \\
\text { Scholz, S. (2004). } \\
\text { Auditor Independence, } \\
\text { Non-Audit Services, } \\
\text { and Restatements: Was } \\
\text { the U.S. Government } \\
\text { Right?. Journal of } \\
\text { Accounting Research, }\end{array}$ & $\begin{array}{l}\text { The authors examine } \\
\text { whether non-audit services } \\
\text { fees are related to the } \\
\text { restatement of financial } \\
\text { statements. } \\
\text { The authors exploit the } \\
\text { data from the period prior } \\
\text { to the mandatory }\end{array}$ & $\begin{array}{l}\text { The authors use regression } \\
\text { analysis to link the test } \\
\text { variables and controls. } \\
\text { The authors use several } \\
\text { public sources such as the } \\
\text { Lexis-Nexis News, Securities } \\
\text { Class Action Alert, and Form } \\
\text { 8-K library files to identify all }\end{array}$ & $\begin{array}{l}\text { The authors do not find a statistically } \\
\text { significant relationship between } \\
\text { restatement and fees for financial } \\
\text { information system design and } \\
\text { implementation or internal audit services. } \\
\text { The authors do find a significant positive } \\
\text { relationship between unspecified non-audit } \\
\text { services and restatements. In contrast, they } \\
\text { find a significant negative relationship }\end{array}$ \\
\hline
\end{tabular}




\begin{tabular}{|c|c|c|c|}
\hline $42,561-588$ & $\begin{array}{l}\text { requirements for fees } \\
\text { disclosure. }\end{array}$ & $\begin{array}{l}\text { interim and annual } \\
\text { restatement published from } \\
\text { 1st January } 1995 \text { - } 31_{\text {st }} \\
\text { December 2000. They } \\
\text { include all GAAP violation } \\
\text { restatements of U.S. } \\
\text { companies and exclude } \\
\text { restatements that related to } \\
\text { GAAP-to-GAAP accounting } \\
\text { changes. They also exclude } \\
\text { firms that are not audited by } \\
\text { one of the largest seven U.S. } \\
\text { audit firms. Then, they match } \\
\text { the restating firms with non- } \\
\text { restating firms for a similar } \\
\text { period, similar industry, } \\
\text { similar audit firm, and nearest } \\
\text { revenue. The fees data is } \\
\text { privately obtained from the }\end{array}$ & $\begin{array}{l}\text { between tax services fees and restatements. } \\
\text { This result holds when the authors use the } \\
\text { overall sample and for subsamples of } \\
\text { matched pairs, Form } 10 \mathrm{~K} \text { restatements, } \\
\text { material misstatements, fees of } \$ 1 \text { million } \\
\text { or more, and larger registrants. The authors } \\
\text { argue that the results indicate the benefits } \\
\text { resulting from APTS. }\end{array}$ \\
\hline
\end{tabular}




\begin{tabular}{|c|c|c|c|c|}
\hline & & & $\begin{array}{l}\text { largest seven U.S. auditing } \\
\text { firms. The authors also use } \\
\text { several other data sources } \\
\text { such as the Compustat and } \\
\text { SEC EDGAR databases. } \\
\text { The final sample consists of } \\
979 \text { fee-year observations on } \\
617 \text { restating registrant U.S. } \\
\text { firms. }\end{array}$ & \\
\hline 23 & $\begin{array}{l}\text { Klassen, K. J., \& } \\
\text { Laplante, S. K. } \\
\text { (2012a). Are U.S. } \\
\text { Multinational } \\
\text { Corporations Becoming } \\
\text { More Aggressive } \\
\text { Income Shifters?. } \\
\text { Journal of Accounting } \\
\text { Research, 50, 1245- }\end{array}$ & $\begin{array}{l}\text { The authors examine the } \\
\text { extent of } \\
\text { multijurisdictional income } \\
\text { shifting by U.S. } \\
\text { multinationals. They also } \\
\text { examine whether income } \\
\text { shifting has changed } \\
\text { overtime ( } 22 \text { years sample } \\
\text { period). }\end{array}$ & $\begin{array}{l}\text { The authors use regression } \\
\text { analysis to link the test } \\
\text { variables and controls. } \\
\text { The authors gather a sample } \\
\text { from all U.S. firms with } \\
\text { foreign sales, pre-tax } \\
\text { earnings, and tax information } \\
\text { from Compustat during the }\end{array}$ & $\begin{array}{l}\text { The authors find that U.S. companies have } \\
\text { become more active in shifting income to } \\
\text { foreign jurisdictions. Holding constant tax } \\
\text { rate differences between U.S. and foreign } \\
\text { jurisdictions, they estimate that } 380 \\
\text { corporations with low average foreign tax } \\
\text { rates have shifted approximately } \$ 10 \\
\text { billion of additional more income out of } \\
\text { the United States annually during } 2005-\end{array}$ \\
\hline
\end{tabular}




\begin{tabular}{|c|c|c|c|c|}
\hline & 1285. & & $\begin{array}{l}\text { period } 1988-2009 . \\
\text { Observations are excluded if } \\
\text { firms do not have five-year } \\
\text { data to calculate average } \\
\text { foreign tax rate incentives, } \\
\text { have negative five-year } \\
\text { summed pre-tax domestic or } \\
\text { foreign income, and have } \\
\text { average foreign tax rate } \\
\text { incentive less than } 1 \text { or } \\
\text { greater than } 1 . \text { The final } \\
\text { sample consists of } 8,074 \\
\text { firm-year observations. }\end{array}$ & $\begin{array}{l}2009 \text { relative to } 1998-2002 . \\
\text { Furthermore, they find that firms with low } \\
\text { average foreign tax rates shifted income } \\
\text { more aggressively out of the U.S. } \\
\text { following declining IRS audit intensity, a } \\
\text { beneficial U.S. tax law change, and a } \\
\text { marked increase in non-U.S. transfer } \\
\text { pricing enforcement activities. }\end{array}$ \\
\hline 24 & $\begin{array}{l}\text { Klassen, K. J., \& } \\
\text { Laplante, S. K. } \\
\text { (2012b). The Effect of } \\
\text { Foreign Reinvestment } \\
\text { and Financial } \\
\text { Reporting Incentives on }\end{array}$ & $\begin{array}{l}\text { The authors examine two } \\
\text { issues relating to the } \\
\text { tendency of U.S. } \\
\text { multinationals to shift } \\
\text { income between the U.S. } \\
\text { and foreign jurisdictions. }\end{array}$ & $\begin{array}{l}\text { The authors use regression } \\
\text { analysis to link the test } \\
\text { variables and controls. } \\
\text { The authors gather, from the } \\
\text { Compustat database, a sample }\end{array}$ & $\begin{array}{l}\text { The authors argue that when the foreign } \\
\text { tax rate is less than the domestic tax rate, } \\
\text { there are two types of firms based on their } \\
\text { reinvestment-related incentives. First, } \\
\text { firms with a foreign subsidiary viewed as } \\
\text { having low reinvestment-related incentives }\end{array}$ \\
\hline
\end{tabular}




\begin{tabular}{|c|c|c|c|}
\hline $\begin{array}{l}\text { Cross-Jurisdictional } \\
\text { Income Shifting. } \\
\text { Contemporary } \\
\text { Accounting Research, } \\
29,928-955 .\end{array}$ & $\begin{array}{l}\text { First, they test whether } \\
\text { foreign reinvestment- } \\
\text { related incentives } \\
\text { influence income shifting } \\
\text { by multinationals. Second, } \\
\text { they test whether financial } \\
\text { reporting incentives } \\
\text { influence income shifting } \\
\text { behaviour. }\end{array}$ & $\begin{array}{l}\text { from all U.S. firms with } \\
\text { foreign sales during the } 1993 \\
-2006 \text { period. Observations } \\
\text { are excluded if firms have } \\
\text { negative five-year summed } \\
\text { pre-tax domestic or foreign } \\
\text { income and have average } \\
\text { foreign tax rate incentive less } \\
\text { than } 1 \text { or greater than } 1 . \text { The } \\
\text { final sample consists of } 3,829 \\
\text { firm-year observations. }\end{array}$ & $\begin{array}{l}\text { because the foreign operations are mature } \\
\text { and so further income shifting is not a } \\
\text { value maximizing activity. Second, firms } \\
\text { with a foreign subsidiary viewed as having } \\
\text { high reinvestment-related incentives and so } \\
\text { the firm tends to shift income to that } \\
\text { foreign subsidiary. The authors find that } \\
\text { firms with low foreign tax rates relative to } \\
\text { domestic tax rates shift significantly more } \\
\text { income from U.S. to the foreign } \\
\text { subsidiaries with high reinvestment-related } \\
\text { incentives. However, they do not find that } \\
\text { reinvestment incentives affect income } \\
\text { shifting into the U.S. } \\
\text { Related to the second issue, they argue that } \\
\text { financial reporting rules allow firms to } \\
\text { avoid recording deferred taxes on the } \\
\text { financial statements if they decide earnings }\end{array}$ \\
\hline
\end{tabular}




\begin{tabular}{|c|c|c|c|c|}
\hline & & & & $\begin{array}{l}\text { as permanently reinvested. They find that } \\
\text { more aggressive financial reporting firms } \\
\text { and those that report lower tax expense by } \\
\text { designating earnings outside the U.S as } \\
\text { permanently reinvested, are more } \\
\text { responsive to income shifting incentives } \\
\text { than other firms even after controlling for } \\
\text { reinvestment incentives. This shows that } \\
\text { firms with greater financial reporting } \\
\text { incentives shift more income out of U.S. }\end{array}$ \\
\hline 25 & $\begin{array}{l}\text { Krishnan, G. V., \& } \\
\text { Visvanathan, G. } \\
\text { (2011). Is There an } \\
\text { Association between } \\
\text { Earnings Management } \\
\text { and Auditor-Provided } \\
\text { Tax Services?. Journal } \\
\text { of the American } \\
\text { Taxation Association, }\end{array}$ & $\begin{array}{l}\text { The authors examine } \\
\text { whether auditor provided } \\
\text { tax services mitigate } \\
\text { earnings management. In } \\
\text { particular, they investigate } \\
\text { whether auditor provided } \\
\text { tax services prevent } \\
\text { earnings management and } \\
\text { whether tax avoidance is }\end{array}$ & $\begin{array}{l}\text { The authors use regression } \\
\text { analysis to link the test } \\
\text { variables and controls. } \\
\text { For the first research } \\
\text { question, the authors gather } \\
\text { the sample from the } \\
\text { Compustat over the period } \\
2000-2007 \text {. They then }\end{array}$ & $\begin{array}{l}\text { They find a negative relationship between } \\
\text { auditor provided tax services and earnings } \\
\text { management as measured by loss } \\
\text { avoidance. This result is robust to the } \\
\text { authors using only a sample that reports } \\
\text { tax fees and a matched sample of } \\
\text { observations with and without tax fees. } \\
\text { They also find that in the pre-SOX period, }\end{array}$ \\
\hline
\end{tabular}




\begin{tabular}{|c|c|c|c|}
\hline $33,111-135$ & $\begin{array}{l}\text { related to auditor provided } \\
\text { tax services. }\end{array}$ & $\begin{array}{l}\text { merge this data with the } \\
\text { Audit Analytics to obtain fees } \\
\text { paid to auditor information. } \\
\text { The final sample for the first } \\
\text { question is } 2,935 \text { firm-year } \\
\text { observations ( } 1,750 \text { unique } \\
\text { firms). } \\
\text { For the second research } \\
\text { question, the authors } \\
\text { construct a new sample by } \\
\text { combining Compustat data } \\
\text { and Audit Analytics data } \\
\text { during the period } 2000 \text { - } \\
2007 \text {. The final sample for } \\
\text { the second research question } \\
\text { is } 6,299 \text { firm-year } \\
\text { observations. }\end{array}$ & $\begin{array}{l}\text { auditor provided tax services are positively } \\
\text { related to earnings management, while in } \\
\text { the post-SOX period, auditor provided tax } \\
\text { services are negatively related to earnings } \\
\text { management. } \\
\text { They find that auditor provided tax } \\
\text { services are negative and significantly } \\
\text { related to earnings management for firms } \\
\text { with a large book-tax difference. The result } \\
\text { is also robust to the authors controlling for } \\
\text { endogeneity and using alternative model } \\
\text { specifications and measurement of } \\
\text { earnings management. However, they find } \\
\text { that their result is driven by larger firms } \\
\text { (firms with assets more than } \$ 200 \text { million). } \\
\text { Furthermore, for the relationship between } \\
\text { auditor provided tax services and tax }\end{array}$ \\
\hline
\end{tabular}




\begin{tabular}{|c|c|c|c|c|}
\hline & & & & $\begin{array}{l}\text { avoidance, they do not find any evidence } \\
\text { to support the argument that auditor } \\
\text { provided tax services influence tax } \\
\text { avoidance activities. This result is robust to } \\
\text { using several alternative measures of tax } \\
\text { avoidance and model specifications. }\end{array}$ \\
\hline 26 & $\begin{array}{l}\text { Krishnan, G. V., } \\
\text { Visvanathan, G., \& Yu, } \\
\text { W. (2013). Do Auditor- } \\
\text { Provided Tax Services } \\
\text { Enhance or Impair the } \\
\text { Value Relevance of } \\
\text { Earnings?. Journal of } \\
\text { the American Taxation } \\
\text { Association, 35(1), 1- } \\
19 .\end{array}$ & $\begin{array}{l}\text { The authors investigate the } \\
\text { influence of auditor } \\
\text { provided tax services on } \\
\text { investors' valuation. }\end{array}$ & $\begin{array}{l}\text { The authors use regression } \\
\text { analysis to link the test } \\
\text { variables and controls. } \\
\text { The authors gather the data } \\
\text { from the Audit Analytics and } \\
\text { Compustat database. The } \\
\text { final sample consists of } \\
27,919 \text { firm-year observations } \\
\text { of U.S. firms over the period } \\
2000 \text { - } 2008 \text {. }\end{array}$ & $\begin{array}{l}\text { The authors find a positive relationship } \\
\text { between the ratio of tax fees to total fees } \\
\text { and the value-relevance of earnings. } \\
\text { Moreover, they find a lower value- } \\
\text { relevance for earnings in the year when } \\
\text { firms switch from their auditor to other } \\
\text { providers of tax services. They argue that } \\
\text { the results provide evidence that investors } \\
\text { perceive auditor provided tax services as } \\
\text { providing benefits through knowledge } \\
\text { spillover effects. }\end{array}$ \\
\hline 27 & $\begin{array}{l}\text { Krishnan, J., Sami, H., } \\
\text { \& Zhang, Y. (2005). }\end{array}$ & $\begin{array}{l}\text { The authors examine } \\
\text { whether the provision of }\end{array}$ & $\begin{array}{l}\text { The authors use regression } \\
\text { analysis to link the test }\end{array}$ & $\begin{array}{l}\text { The authors find a negative relationship } \\
\text { between the ratio of non-audit fees to total }\end{array}$ \\
\hline
\end{tabular}




\begin{tabular}{|c|c|c|c|}
\hline $\begin{array}{l}\text { Does the Provision of } \\
\text { Nonaudit Services } \\
\text { Affect Investor } \\
\text { Perceptions of Auditor } \\
\text { Independence? } \\
\text { Auditing: A Journal of } \\
\text { Practice \& Theory, 24, } \\
\text { 111-135. }\end{array}$ & $\begin{array}{l}\text { non-audit services by } \\
\text { auditors is perceived as } \\
\text { impairing auditor } \\
\text { independence in } \\
\text { appearance. They examine } \\
\text { the relationship between } \\
\text { non-audit services fees and } \\
\text { the earnings response } \\
\text { coefficient for the first, } \\
\text { second, and third quarters } \\
\text { following the release of } \\
\text { proxies containing fee } \\
\text { disclosures. }\end{array}$ & $\begin{array}{l}\text { variables and controls. } \\
\text { The sample consists of U.S. } \\
\text { firms that filed proxies in } \\
\text { 2001. The authors eliminate } \\
\text { firms that change auditors } \\
\text { during the } 2001 \text { period, firms } \\
\text { with missing earnings } \\
\text { announcement dates, firms } \\
\text { with missing earnings per } \\
\text { share information on the } \\
\text { I/B/E/S database, and firms } \\
\text { with earnings announcement } \\
\text { later than December } 2001 . \\
\text { The authors use several other } \\
\text { sources such as the } \\
\text { Compustat, CRSP, and } \\
\text { I/B/E/S database to gather }\end{array}$ & $\begin{array}{l}\text { fees and the earnings response coefficient. } \\
\text { They also find a negative relationship } \\
\text { between the amount of non-audit fees and } \\
\text { the earnings response coefficient. Those } \\
\text { relationships exist in first, second, and } \\
\text { third quarters. For unexpected fees, the } \\
\text { authors find that there is no relationship in } \\
\text { the first quarter except for the ratio of non- } \\
\text { audit fees to total fees. However, they find } \\
\text { significant relationships in the second and } \\
\text { third quarter. They argue that the results } \\
\text { provide evidence that investors perceive } \\
\text { auditor independence impairment as a } \\
\text { result of non-audit services. The results } \\
\text { are robust to the authors considering only } \\
\text { Big5 clients. }\end{array}$ \\
\hline
\end{tabular}




\begin{tabular}{|c|c|c|c|c|}
\hline & & & $\begin{array}{l}\text { necessary information. } \\
\text { The final sample consists of } \\
2,816 \text { firms for the model } \\
\text { using actual fees and } 2,390 \\
\text { for the model using } \\
\text { unexpected fees. }\end{array}$ & $\begin{array}{l}\text { association between non-audit services and } \\
\text { earnings response coefficient. This } \\
\text { indicates that reputation and litigation risks } \\
\text { may help maintain auditor independence. } \\
\text { Regarding the influence of market-to-book } \\
\text { ratio, they find limited evidence of } \\
\text { impairment of auditor independence in the } \\
\text { first and third quarters for small market-to- } \\
\text { book ratios firms, and no association } \\
\text { between non-audit services and earnings } \\
\text { response coefficient for firms with high } \\
\text { market-to-book ratios. }\end{array}$ \\
\hline 28 & $\begin{array}{l}\text { Lisic, L. L. (2014). } \\
\text { Auditor-Provided Tax } \\
\text { Services and Earnings } \\
\text { Management in Tax } \\
\text { Expense: The } \\
\text { Importance of Audit } \\
\text { Committees. Journal of }\end{array}$ & $\begin{array}{l}\text { The author examines the } \\
\text { influence of audit } \\
\text { committee effectiveness } \\
\text { on the relationship } \\
\text { between auditor provided } \\
\text { tax services and earnings } \\
\text { management through tax }\end{array}$ & $\begin{array}{l}\text { The author uses regression } \\
\text { analysis to link the test } \\
\text { variables and controls. } \\
\text { The sample consists of S\&P } \\
\text { firms for the year } 2003 \text {. The } \\
\text { author excludes financial and }\end{array}$ & $\begin{array}{l}\text { The author argues that because auditor } \\
\text { provided tax services need to be approved } \\
\text { by the audit committee, the characteristics } \\
\text { of the committee may influence the } \\
\text { approval process. The author argues that } \\
\text { the probability that an effective audit } \\
\text { committee approves auditor provided tax }\end{array}$ \\
\hline
\end{tabular}




\begin{tabular}{|c|c|c|c|}
\hline $\begin{array}{l}\text { Accounting, Auditing } \\
\& \text { Finance, 29, 340- } \\
366 .\end{array}$ & expense. & $\begin{array}{l}\text { utility firms, firms that } \\
\text { change auditors during the } \\
\text { year, firms with missing } \\
\text { values of necessary data, } \\
\text { firms with negative pre-tax } \\
\text { income or negative Q4 } \\
\text { effective tax rates, firms that } \\
\text { do not purchase tax services } \\
\text { from auditors. } \\
\text { The author relies on several } \\
\text { data sources. The author hand } \\
\text { collects the fees data and } \\
\text { audit committee information } \\
\text { from proxy statements. } \\
\text { Analyst forecast and actual } \\
\text { earnings per share data are } \\
\text { obtained from the I/B/E/S } \\
\text { database, while accounting }\end{array}$ & $\begin{array}{l}\text { services that impair auditor independence } \\
\text { is low. In the event that such audit } \\
\text { committees approve those services, then } \\
\text { they will provide a better monitoring } \\
\text { mechanism to lower the potential } \\
\text { impairment of independence. As a } \\
\text { consequence, effective audit committees } \\
\text { are more likely to induce knowledge } \\
\text { spillover effects resulting from auditor } \\
\text { provided tax services, and thereby a lower } \\
\text { level of earnings management. } \\
\text { The author focuses on earnings } \\
\text { management through the tax expense } \\
\text { account because independence impairment } \\
\text { or knowledge spillover effects from } \\
\text { auditor provided tax services are more } \\
\text { likely to occur through that account. }\end{array}$ \\
\hline
\end{tabular}




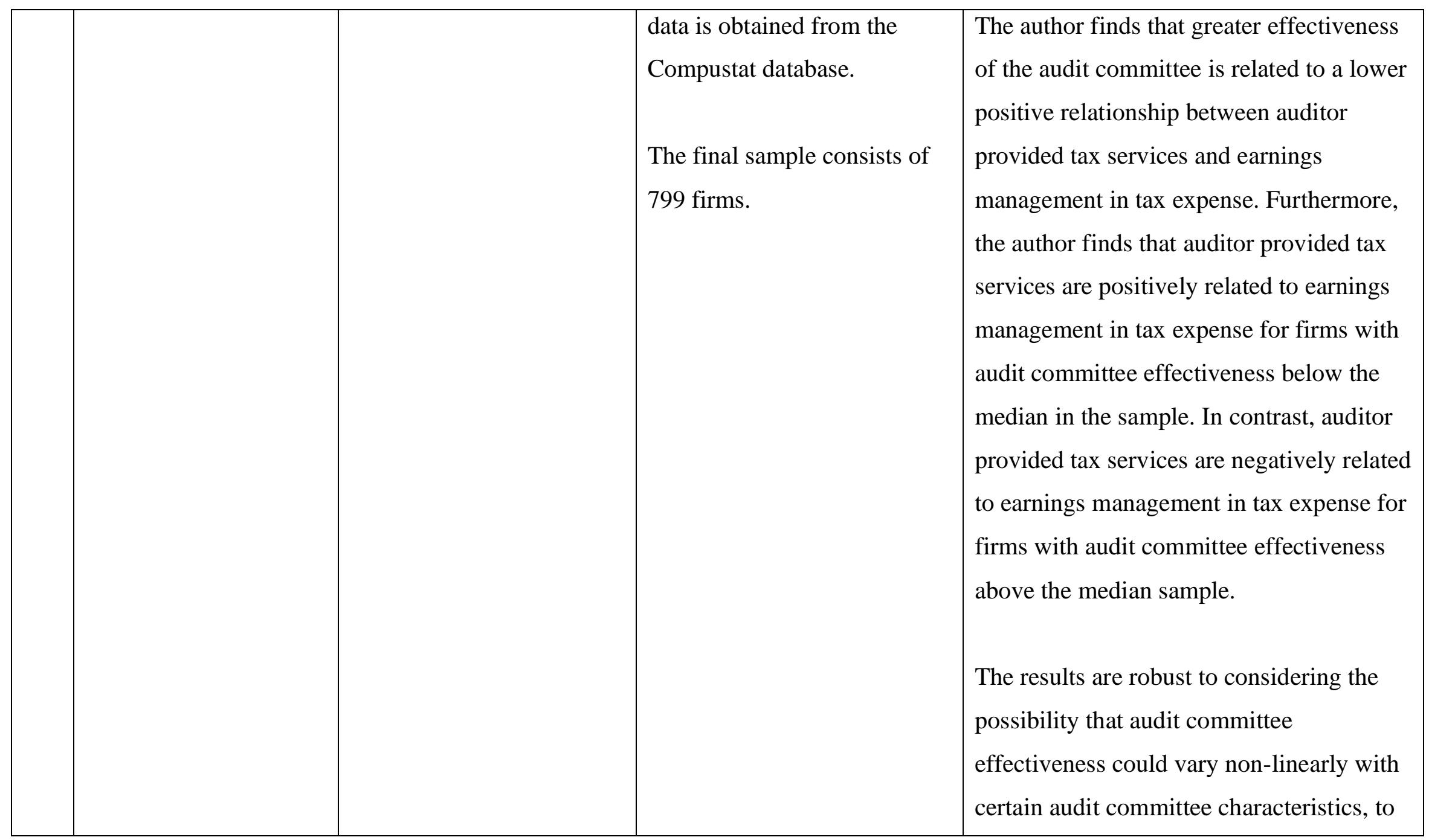




\begin{tabular}{|c|c|c|c|c|}
\hline & & & & $\begin{array}{l}\text { controlling for overall corporate } \\
\text { governance, and addressing endogeneity } \\
\text { concerns. Furthermore, the author does not } \\
\text { find that the relationship between auditor } \\
\text { provided tax services and discretionary } \\
\text { accruals is related to audit committee } \\
\text { effectiveness. This suggests that focusing } \\
\text { on earnings management in tax expense } \\
\text { leads to better detection of the impact of } \\
\text { auditor provided tax services on earnings } \\
\text { management. The author also finds that the } \\
\text { result is externally valid by obtaining } \\
\text { similar results for } 250 \text { S\&P } 500 \text { companies } \\
\text { in } 2009 \text {. }\end{array}$ \\
\hline 29 & $\begin{array}{l}\text { Maydew, E., and } \\
\text { Shackelford, D. (2007). } \\
\text { The changing role of } \\
\text { auditors in corporate } \\
\text { tax planning. In: }\end{array}$ & $\begin{array}{l}\text { The authors examine the } \\
\text { influence of accounting } \\
\text { events such as accounting } \\
\text { scandals, the passage of } \\
\text { the Sarbanes-Oxley Act, }\end{array}$ & $\begin{array}{l}\text { The authors use data } \\
\text { description approach to draw } \\
\text { conclusions. } \\
\text { The sample is S\&P } 500 \text { firms }\end{array}$ & $\begin{array}{l}\text { The authors find that S\&P } 500 \text { companies } \\
\text { pay similar amounts of fees for audit and } \\
\text { for tax work to their auditors in the year } \\
2001 \text {. However, in the year } 2003 \text {, the } \\
\text { amount paid for audit work is twice that }\end{array}$ \\
\hline
\end{tabular}




\begin{tabular}{|c|c|c|c|c|}
\hline & $\begin{array}{l}\text { Auerbach, A., Hines, J., } \\
\text { Slemrod, J. (Eds.), } \\
\text { Taxing Corporate } \\
\text { Income in the } 21 \text { st } \\
\text { Century. Cambridge } \\
\text { University Press, New } \\
\text { York, NY, pp. } 307- \\
337 .\end{array}$ & $\begin{array}{l}\text { and SEC and PCAOB } \\
\text { regulatory actions on the } \\
\text { changing role of auditors } \\
\text { in corporate tax planning. }\end{array}$ & $\begin{array}{l}\text { as of } 31_{\text {st }} \text { December } 2003 . \\
\text { The authors collect auditor } \\
\text { fees data from firm proxy } \\
\text { statements. They exclude } \\
\text { firms with missing tax fees } \\
\text { information in the years } 2001 \\
-2003 \text {. The final sample is } \\
248 \text { companies that report } \\
\text { both audit and tax fees. }\end{array}$ & $\begin{array}{l}\text { for tax work. Further, they estimate that } \\
\text { those companies would pay four times for } \\
\text { the audit work compared to tax work in the } \\
\text { year } 2004 \text {. They also find that tax practice } \\
\text { of the largest accounting firms is stable } \\
\text { during that period. The results may show } \\
\text { that the decline of tax work of incumbent } \\
\text { auditors is related to shift in clients among } \\
\text { the providers of tax services. }\end{array}$ \\
\hline 30 & $\begin{array}{l}\text { McGuire, S. T., Omer, } \\
\text { T. C., \& Wang, D. } \\
\text { (2012). Tax Avoidance: } \\
\text { Does Tax-Specific } \\
\text { Industry Expertise } \\
\text { Make a Difference?. } \\
\text { The Accounting } \\
\text { Review, 87(3), 975- } \\
1003 .\end{array}$ & $\begin{array}{l}\text { The authors examine the } \\
\text { relationship between } \\
\text { auditor tax-specific } \\
\text { industry expertise and } \\
\text { company tax avoidance. }\end{array}$ & $\begin{array}{l}\text { The authors use regression } \\
\text { analysis to link the test } \\
\text { variables and controls. } \\
\text { The authors gather the data } \\
\text { from the Audit Analytics and } \\
\text { Compustat databases for the } \\
\text { period } 2002 \text { - 2009. They } \\
\text { exclude observations with } \\
\text { negative pre-tax income, with }\end{array}$ & $\begin{array}{l}\text { The authors find that companies that } \\
\text { purchase tax services from a tax expert } \\
\text { auditor engage in greater tax avoidance. } \\
\text { Furthermore, they find that overall } \\
\text { expertise (audit and tax) of auditors is } \\
\text { related to greater tax avoidance. They } \\
\text { argue that this result indicates that auditors } \\
\text { with high overall expertise are capable of } \\
\text { combining their audit and tax expertise in } \\
\text { term of developing tax strategies that }\end{array}$ \\
\hline
\end{tabular}




\begin{tabular}{|c|c|c|c|c|}
\hline & & & $\begin{array}{l}0 \text { tax fees paid to external } \\
\text { auditors, and industry and } \\
\text { MSA market with less than } \\
\text { two audit firms and two } \\
\text { clients. The final sample } \\
\text { consists of } 8,025 \text { firm-year } \\
\text { observations for } 2,513 \text { unique } \\
\text { firms. }\end{array}$ & $\begin{array}{l}\text { benefit clients from both tax and financial } \\
\text { statement perspectives. Overall, the results } \\
\text { suggest that auditors tax-specific industry } \\
\text { expertise influences clients' tax avoidance. }\end{array}$ \\
\hline 31 & $\begin{array}{l}\text { Paterson, J. S., \& } \\
\text { Valencia, A. (2011). } \\
\text { The Effects of } \\
\text { Recurring and } \\
\text { Nonrecurring Tax, } \\
\text { Audit-Related, and } \\
\text { Other Nonaudit } \\
\text { Services on Auditor } \\
\text { Independence: Effects } \\
\text { of Recurring and } \\
\text { Nonrecurring Nonaudit }\end{array}$ & $\begin{array}{l}\text { The authors investigate the } \\
\text { relationship between non- } \\
\text { audit services and auditor } \\
\text { independence and } \\
\text { distinguish between } \\
\text { recurring and non- } \\
\text { recurring non-audit } \\
\text { services. In particular, they } \\
\text { examine whether financial } \\
\text { restatements are a function } \\
\text { of recurring non-audit }\end{array}$ & $\begin{array}{l}\text { The authors use regression } \\
\text { analysis to link the test } \\
\text { variables and controls. } \\
\text { The authors use the Audit } \\
\text { Analytics database to obtain } \\
\text { information about restated } \\
\text { financial statements. They } \\
\text { include only restatements for } \\
\text { accounting rule application } \\
\text { failures, financial fraud, }\end{array}$ & $\begin{array}{l}\text { The authors find that recurring auditor } \\
\text { provided tax services are negatively related } \\
\text { to restatements. } \\
\text { They find that non-recurring auditor } \\
\text { provided tax services are positively related } \\
\text { to restatements and thus conclude that the } \\
\text { evidence in earlier studies indicating } \\
\text { knowledge spillover rather than } \\
\text { impairment of independence must have } \\
\text { been dominated by recurring assignments. }\end{array}$ \\
\hline
\end{tabular}




\begin{tabular}{|c|c|c|c|}
\hline $\begin{array}{l}\text { Services. } \\
\text { Contemporary } \\
\text { Accounting Research, } \\
28,1510-1536 .\end{array}$ & services. & $\begin{array}{l}\text { irregularities, and } \\
\text { misrepresentations. } \\
\text { Restatements related to non- } \\
\text { financial statement } \\
\text { disclosures, omissions, or } \\
\text { corrections and errors } \\
\text { involving clerical } \\
\text { applications are excluded } \\
\text { from the sample. } \\
\text { The authors gather auditor, } \\
\text { audit fees, and non-audit fees } \\
\text { from the Audit Analytics } \\
\text { database, accounting data is } \\
\text { obtained from the Compustat, } \\
\text { and stock returns data is } \\
\text { gathered from the Eventus } \\
\text { database. }\end{array}$ & $\begin{array}{l}\text { However, the significant relationship } \\
\text { applies only to restatements associated } \\
\text { with cumulative abnormal returns below } \\
\text { the mean. For the full sample, they do not } \\
\text { find a significant relationship between } \\
\text { non-recurring tax services and } \\
\text { restatements. } \\
\text { For the other services of non-audit } \\
\text { services, they find that recurring and non- } \\
\text { recurring engagements are both positively } \\
\text { associated with restatements and their } \\
\text { difference is not statistically significant. } \\
\text { They conclude that non-recurring tax and } \\
\text { audit-related non-audit services have a } \\
\text { greater threat to auditor independence } \\
\text { compare to the recurring ones. }\end{array}$ \\
\hline
\end{tabular}




\begin{tabular}{|c|c|c|c|c|}
\hline & & & $\begin{array}{l}\text { The sample comprises data } \\
\text { on 7,042 U.S. firms during } \\
\text { the period } 2003 \text { - } 2006 \text {. } \\
\text { Specifically, 1,709 firms with } \\
3,232 \text { restatement and 5,333 } \\
\text { firms with } 15,087 \text { non- } \\
\text { restatement observations. }\end{array}$ & \\
\hline 32 & $\begin{array}{l}\text { Rego, S. O. (2003). } \\
\text { Tax-Avoidance } \\
\text { Activities of U.S. } \\
\text { Multinational } \\
\text { Corporations. } \\
\text { Contemporary } \\
\text { Accounting Research, } \\
20(4), 805-833 .\end{array}$ & $\begin{array}{l}\text { The author examines the } \\
\text { effect of firm } \\
\text { characteristics such as size } \\
\text { and profitability on the } \\
\text { extent of tax avoidance } \\
\text { activities. }\end{array}$ & $\begin{array}{l}\text { The author uses regression } \\
\text { analysis to link the test } \\
\text { variables and controls. } \\
\text { The author examines the } \\
\text { issues on a broad sample of } \\
\text { U.S. domestic and } \\
\text { multinational corporations } \\
\text { (broader sample). The author } \\
\text { also tests the issues on a sub- } \\
\text { sample of U.S. multinational }\end{array}$ & $\begin{array}{l}\text { The author finds that larger firms, both for } \\
\text { the full sample and for just U.S. } \\
\text { multinationals, have higher worldwide } \\
\text { ETRs than smaller firms. The author } \\
\text { argues that it supports the argument that } \\
\text { larger firms face political costs which limit } \\
\text { their tax avoidance activities. Further, the } \\
\text { author finds, for the full sample, that firms } \\
\text { with higher income have lower worldwide } \\
\text { ETRs. Specifically for U.S. multinationals, } \\
\text { the author finds that worldwide ETRs are }\end{array}$ \\
\hline
\end{tabular}




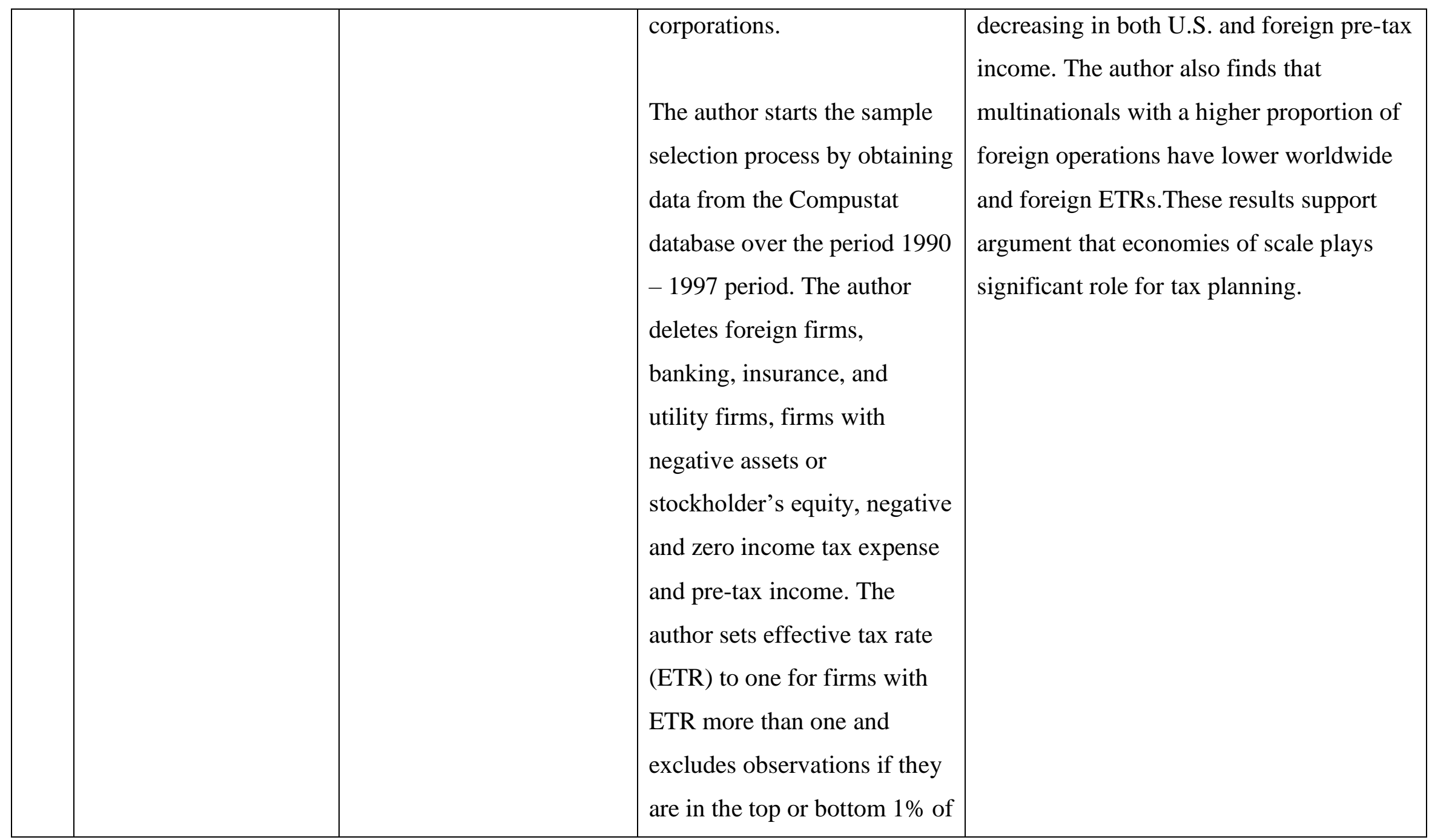




\begin{tabular}{|c|c|c|c|c|}
\hline & & & $\begin{array}{l}\text { the distribution of return on } \\
\text { assets to eliminate the effect } \\
\text { of extreme values. This } \\
\text { specification yields } 19,737 \\
\text { firm-year observations on } \\
\text { 5,379 U.S. firms. }\end{array}$ & \\
\hline 33 & $\begin{array}{l}\text { Robinson, D. (2008). } \\
\text { Auditor Independence } \\
\text { and Auditor-Provided } \\
\text { Tax Service: Evidence } \\
\text { from Going-Concern } \\
\text { Audit Opinions Prior to } \\
\text { Bankruptcy Filings. } \\
\text { Auditing, 27, 31-54. }\end{array}$ & $\begin{array}{l}\text { By focusing on bankruptcy } \\
\text { firms, the author } \\
\text { investigates the } \\
\text { relationship between } \\
\text { auditor provided tax } \\
\text { services and auditor } \\
\text { independence as reflected } \\
\text { in the issue of correct } \\
\text { going-concern opinions. }\end{array}$ & $\begin{array}{l}\text { The author uses regression } \\
\text { analysis to link the test } \\
\text { variables and controls. } \\
\text { The sample consists of } 209 \\
\text { U.S. bankrupt firms obtained } \\
\text { from the New Generation } \\
\text { Inc.'s Bankruptcy Datasource } \\
\text { over the period } 2001 \text { - } 2004 \text {. } \\
\text { The author also uses other } \\
\text { databases such as the } \\
\text { Compustat for calculating }\end{array}$ & $\begin{array}{l}\text { The author does not find a significant } \\
\text { relationship between audit or non-audit } \\
\text { fees to the probability of issuing a going- } \\
\text { concern opinion. However, after dividing } \\
\text { the non-audit fees into tax and non-tax } \\
\text { fees, The author finds a positive } \\
\text { relationship between tax fees and the } \\
\text { issuance of a correct going-concern } \\
\text { opinion prior to a bankruptcy filing. } \\
\text { The author argues that the results indicate } \\
\text { that auditors who also provide tax services }\end{array}$ \\
\hline
\end{tabular}




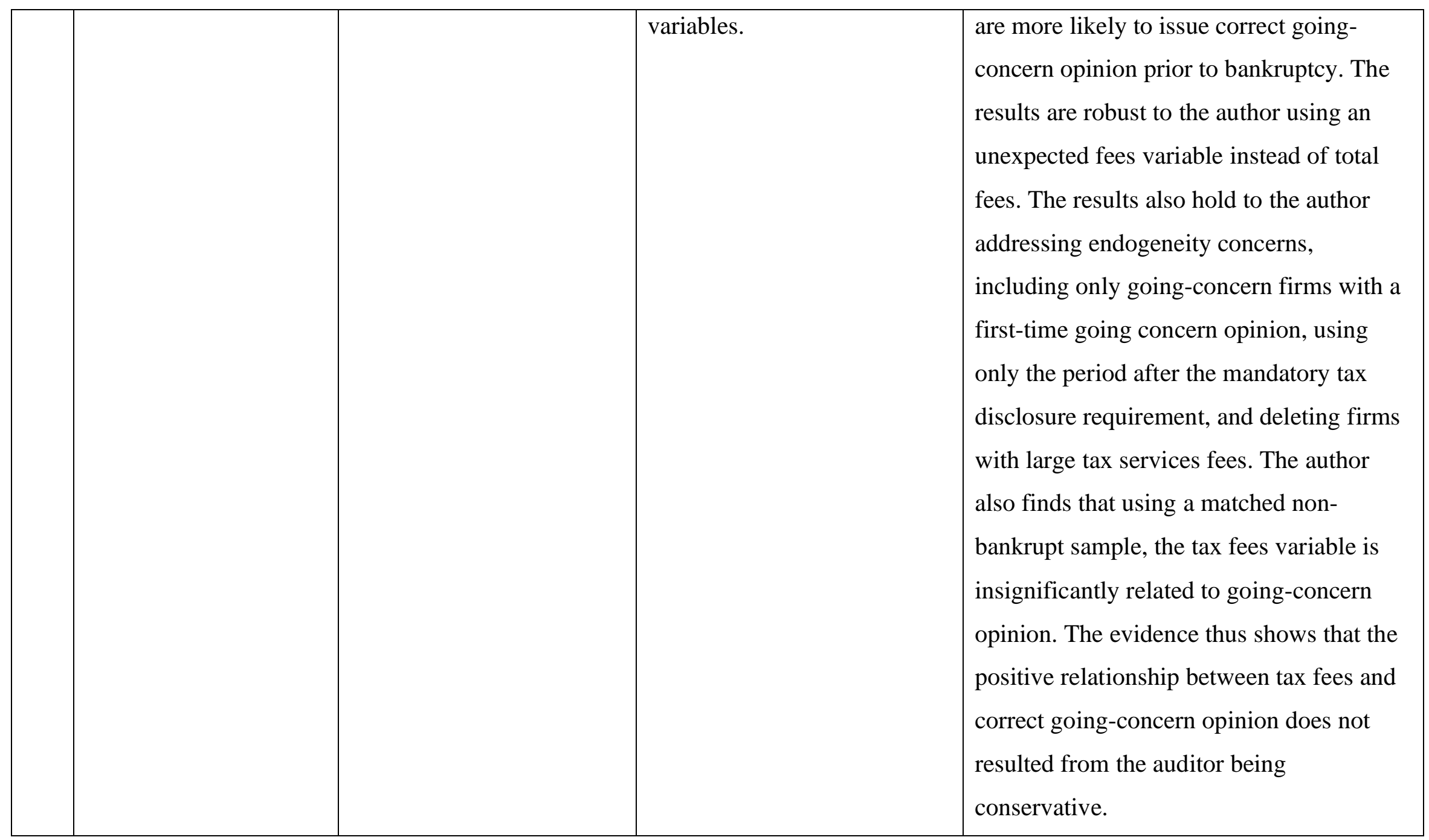




\begin{tabular}{|c|c|c|c|c|}
\hline 34 & $\begin{array}{l}\text { Seetharaman, A., Sun, } \\
\text { Y., \& Wang, W. } \\
\text { (2011). Tax-Related } \\
\text { Financial Statement } \\
\text { Restatements and } \\
\text { Auditor-Provided Tax } \\
\text { Services. Journal of } \\
\text { Accounting, Auditing } \\
\text { \& Finance, 26, 677- } \\
698 .\end{array}$ & $\begin{array}{l}\text { The authors examine the } \\
\text { influence of auditor } \\
\text { provided tax services on } \\
\text { reporting quality related to } \\
\text { tax. In particular, they } \\
\text { investigate the association } \\
\text { between auditor provided } \\
\text { tax services and tax-related } \\
\text { restatements of financial } \\
\text { statements in the post- } \\
\text { SOX period. }\end{array}$ & $\begin{array}{l}\text { The authors use regression } \\
\text { analysis to link the test } \\
\text { variables and controls. } \\
\text { The authors gather the } \\
\text { restatement data from the } \\
\text { Audit Analytics database } \\
\text { during the } 2003 \text { - } 2005 \\
\text { period. To classify whether } \\
\text { restatements are related to } \\
\text { violation of GAAP in respect } \\
\text { of tax, the authors obtain } \\
\text { information from one of the } \\
\text { Big4 accounting firms that } \\
\text { maintains information related } \\
\text { to restatements filed with the } \\
\text { SEC. Specifically, tax-related } \\
\text { restatements include those } \\
\text { related to Financial }\end{array}$ & $\begin{array}{l}\text { The authors find a significant negative } \\
\text { relationship between auditor provided tax } \\
\text { services and tax-related restatements of } \\
\text { financial statements. However, they do not } \\
\text { find a significant relationship between } \\
\text { auditor provided tax services and general } \\
\text { restatements. They argue that the results } \\
\text { indicate that firms which purchase auditor } \\
\text { provided tax services benefit from the } \\
\text { knowledge spillover by having fewer tax- } \\
\text { related financial statement problems than } \\
\text { firms that purchase their tax services from } \\
\text { sources other than the incumbent auditor. }\end{array}$ \\
\hline
\end{tabular}




\begin{tabular}{|c|c|c|c|c|}
\hline & & & $\begin{array}{l}\text { Accounting Standard } 109 \\
\text { issues (accounting for income } \\
\text { taxes), improper treatment of } \\
\text { deferred tax liabilities or } \\
\text { assets, valuation allowances, } \\
\text { tax contingencies, sales taxes, } \\
\text { state income taxes, and } \\
\text { foreign taxes or tax credits. } \\
\text { They also rely on the } \\
\text { Compustat database for } \\
\text { necessary accounting } \\
\text { information. The final sample } \\
\text { comprises } 3,888 \text { firm-year } \\
\text { general restatements by } 2,116 \\
\text { firms and } 259 \text { firm-year tax- } \\
\text { related restatements by } 150 \\
\text { firms. }\end{array}$ & \\
\hline 35 & $\begin{array}{l}\text { Simunic, D. A. (1984). } \\
\text { Auditing, Consulting, }\end{array}$ & $\begin{array}{l}\text { The author examines the } \\
\text { decision of firms to }\end{array}$ & $\begin{array}{l}\text { The author uses regression } \\
\text { analysis to link the test }\end{array}$ & $\begin{array}{l}\text { The author finds that firms that purchase } \\
\text { management advisory services have higher }\end{array}$ \\
\hline
\end{tabular}




\begin{tabular}{|l|l|l|l|l|}
\hline $\begin{array}{l}\text { and Auditor } \\
\text { Independence. Journal } \\
\text { of Accounting }\end{array}$ & $\begin{array}{l}\text { purchase management } \\
\text { advisory services and audit } \\
\text { Research, 22, 679-702. }\end{array}$ & $\begin{array}{l}\text { variables and controls. } \\
\text { functions are interrelated } \\
\text { and they investigate the } \\
\text { existence and pricing } \\
\text { effect of knowledge } \\
\text { spillover. }\end{array}$ & $\begin{array}{l}\text { Starting with the sample of } \\
397 \text { observations in Simunic } \\
(1980) \text {, the author includes } \\
\text { companies that use big } 8\end{array}$ & $\begin{array}{l}\text { audit fees compared to firms that do not } \\
\text { purchase those services. The author } \\
\text { concludes that the observed fee increase is } \\
\text { audication of a beneficial knowledge } \\
\text { spillover resulting from the joint provision } \\
\text { of managerial advisory services and audit } \\
\text { on the fees paid to the auditor } \\
\text { services. }\end{array}$ \\
& $\begin{array}{l}\text { for managerial advisory } \\
\text { services during the year } \\
\text { ended December 1976 or } \\
\text { ending in 1977, and report } \\
\text { assets less than } \$ 3 \text { billion. } \\
\text { The final sample comprises } \\
\text { 263 U.S. companies. }\end{array}$ & \\
& &
\end{tabular}

